Chemical sciences Article

THE COMPLEXES OF NEODYMIUM AND DYSPROSIUM WITH GLUTAMIC ACID

Pestovsky Y.S.

\title{
Materials of Conferences
}

PREDICTION OF ISOVALENT SUBSTITUSHIONS OF PB ${ }^{2+} \mathrm{IN} \mathrm{PBZR}_{3} \mathrm{O}_{4} \mathrm{~F}_{6}$ STRUCTURE

Kuchina Y.V., Golubev A.M., Slyn 'ko L.E.

\section{Philological sciences} Article

RANGE OF LINGUISTIC UNITS USING

Kapalbekov B.S.

\section{Physical and mathematical sciences Article}

SIMPLE KELVIN EQUATION APPLICABLE IN THE CRITICAL POINT VICINITY

Valeev A.A.

\section{Biological sciences}

Short Reports

THE DYNAMICS OF THE BIOLOGICAL PRODUCTIVITY OF BIOMES TUVA

Sambuu A.D.

\section{Economical sciences}

Materials of Conferences

CLASSIFICATION OF LOGISTICAL SYSTEMS AND OPTIMIZATION OF GOODS CIRCULATION PROCESSES

Balgabekov T.K., Malybaev S.K., Matkerimov T.Y., Hajbullin R.R.,

Rozhkov A.V., Frolova S.O., Erzhumanova A.K.

THE REAL SECTOR OF ECONOMY PECULIARITIES

Danilina E.I., Gorelov D.V., Malikova Y.E.

SPECIAL FEATURES OF ORGANIZATION-STAFF WORK WITIHN STATE BODIES IN MODERN CONDITIONS: DOMESTIC AND FOREIGH EXPERIENCE

Danilina E.I., Golosova V.A., Shmackov E.V., Piralieva M.I.

PERSONNEL COMPONENT OF INNOVATIVE DEVELOPMENT OF RUSSIAN ECONOMICS

Guremina N.V., Mansurov U.N., Smirnov V.P.

Short Reports

INFLUENCE OF EXPENSES UPON MAKING A DECISION ON UNDERTAKING INFORMAL ACTIVITY

Vidritskaya N.I.

\section{Medical sciences \\ Materials of Conferences}

DIFFERENTIATED APPROACH ENDOTHELIOPATHY IN THE DEVELOPMENT OF IN WOMEN METABOLIC SYNDROME 
THE LEVEL OF CYTOKINES IN THE BLOOD OF PATIENTS WITH ST-ELEVATION ACUTE MYOCARDIAL INFARCTION

Osipova O.A., Suyasova S.B., Shekhovtsova L.V.,

Nagibina A.I., Vlasenko M.A., Vlasenko O.A.

\section{Short Reports}

VISCERAL LYMPH NODES IN ABDOMINAL CAVITY OF DEGUS

Petrenko V.M.

32

Pedagogical sciences

Materials of Conferences

THE USE OF MICRO-NUCLEAR TEST AS A METHOD IN A COMPREHENSIVE ASSESSMENT OF THE STUDENTS' FUNCTIONAL STATE

Abakumova L.V., Khrenkova V.V., Zolotukhin V.V., Roginskaya A.A.

MODERN CHANGES IN REGULATORY BASE OF THE EDUCATIONAL

PROCESS IN UKRAINE AS LEGAL FORMATION BASIS OF EUROPEAN

STANDARDS OF THE SCIENCE AND EDUCATION

Ermolenko T.I., Karnaukh E.V.

CASE - TECHNOLOGY TO STUDYING HUMAN ANATOMY

Ulyanovskaya S.A., Basova L.A., Serebrennikov A.D., Shumakova A.S.,

Smirnov P.V., Rogacheva O.D., Stepyreva A.A.

ENGLISH INTONATION AND THE RUSSIAN LEARNER

Vishnevskaya G.M.

VOCAL SCHOOL OF WEST KAZAKHSTAN REGION

Vorfolomeyeva O.V.

\section{Technical sciences}

Materials of Conferences

PRECISION THICKNESS METER PHASED ARRAY

Guva A.A., Nikonova G.V., Shchelkanov A.I.

THE ACTUAL SCIENTIFIC AND EDUCATIONAL PROGRAM

OF SMALL SPACECRAFTS ENGINEERING

Kovalev I.V.

MEASUREMENT PHASE NOISE CRYSTAL OSCILLATOR

Nikonova G.V., Novikov S.M., Petrov A.V. 


\title{
THE COMPLEXES OF NEODYMIUM AND DYSPROSIUM WITH GLUTAMIC ACID
}

\author{
Pestovsky Y.S. \\ LLCEkolit,Moscow,e-mail: organics@mail.ru
}

\begin{abstract}
The interaction of neodymium and dysprosium chlorides with glutamic acid at pH 7 is studied. The complexes are isolated and characterized with X-ray spectroscopy and FTIR. The complexes of neodymium were characterized with elemental and thermal analysis.
\end{abstract}

Keywords: neodymium, dysprosium, glutamic acid, coordination chemistry

The ability of rare earths for formation complexes with polydentate organic ligands as well as their significant similarity to calcium, which belongs to the biometal group, causes great interest to this field of chemistry. It is well known nowadays that vital significant metals in living organism are included to the coordination complexes. Though not more than $3 \%$ of mass of the human body is the mass of all metals, they are of great significance in the processes proceeding in the organism. All organism presents a harmoniously functioning polymetallic and polyligand system [1].

One can say with certainty that complexes of rare earths with glutamic acid will be widely adopted in very different fields and branches of industry and in the first place in pharmacology as anti-inflammatory [2] and antitumor preparations $[2,3]$. They can also be used in radioelectronics as pyroelectric materials $[4,5]$.

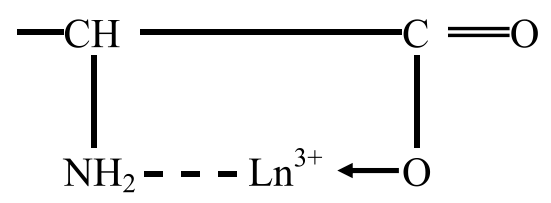

Fig. 1

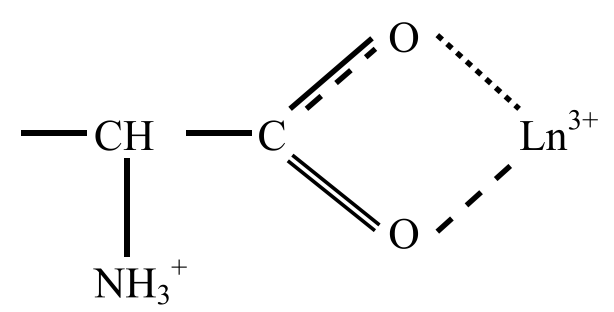

Fig. 2

A whole interest to the complexes of rare earths with glutamic acid was shown about 20 years ago, but the glutamates of rare earths are still studied insufficiently.

Glutamic acid is a low-dentate (potential tridentate) ligand in formation of the coordina- tion compounds with rare earths. The molecule has three donor groups that are amino group and two carboxylic groups. In accordance with its structure glutamic acid can form two different chelate cycles. They are five-membered glycinate cycle and four-membered carboxylic cycle (fig. 1, 2).

In accordance with the Chugaev rule (cycles with five or six links are the most stable) the glycinic cycle is much more stable than the carboxylic one.

The aim of the work was the synthesis and investigation of the coordination complexes of neodymium and dysprosium with glutamic acid.

\section{Materials and methods of research}

Glutamic acid, neodymium chloride hexahydrate, dysprosium oxide, $25 \%$ ammonia and concentrated hydrochloric acid were taken as initial substances and used without further purification.

The solution of dysprosium chloride was prepared by dissolution of dysprosium oxide in concentrated hydrochloric acid. Then the solution was softened by steam and diluted with distilled water to volume of $100 \mathrm{ml}$. The concentration of dysprosium chloride was determined by titration with EDTA.

For the synthesis of the complexes the initial substances were mixed in proportions $1: 1$, $1: 2$ and $1: 3$. The $\mathrm{pH}$ value of the solutions was adjusted to 6-8 with ammonia solution.

Thermal analysis was done by means of a derivatograph Q-1500D Paulik-Paulik-Erdey, temperature interval $20-500^{\circ} \mathrm{C}$, heating velocity $10^{\circ} \mathrm{C}$ per minute, sample mass $20 \mathrm{mg}$. After that the sample was heated in electrical oven at $750^{\circ} \mathrm{C}$ until its mass became constant.

\section{Results of research and their discussion}

The results of physico-chemical analyses of the complexes presented in the Table 1 and Table 2 allow us to make conclusions of chemical pureness of the complexes of neodymium (lacks of stripes of admixtures in X-ray diffraction patterns) and variable hydrate composition and to ascribe definite formulae to them. 
The results of elemental analysis of the complexes of neodymium with glutamic acid

\begin{tabular}{|c|c|c|c|}
\hline \multirow{2}{*}{ Sample } & \multicolumn{2}{|c|}{ Content of Nd, mass \% } & \multirow{2}{*}{ Formulae of the compounds } \\
\cline { 2 - 3 } & found & calculated & \\
\hline$(1)$ & 33,46 & 33,31 & $\mathrm{Nd}(\mathrm{Glu}) \mathrm{Cl} \cdot 6 \mathrm{H}_{2} \mathrm{O}$ \\
\hline$(2)$ & 23,83 & 24,01 & $\mathrm{Nd}(\mathrm{HGlu})_{3} \cdot 2 \mathrm{H}_{2} \mathrm{O}$ \\
\hline$(3)$ & 35,02 & 34,75 & $\mathrm{Nd}(\mathrm{Glu}) \mathrm{Cl}_{2} \cdot 5 \mathrm{H}_{2} \mathrm{O}$ \\
\hline
\end{tabular}

The results of FTIR analysis of the complexes of neodymium and dysprosium

Table 2 with glutamic acid ( $\mathrm{s}$ - strong intensity of a peak, $\mathrm{m}$ - middle intensity of a peak, $\mathrm{w}$ - weak intensity of a peak)

\begin{tabular}{|c|c|c|c|c|c|c|c|}
\hline Compound & $v \begin{array}{c}\mathrm{C}=\mathrm{O} \\
\mathrm{COOH}\end{array}$ & $\delta_{\text {СоОН }}$ & $\begin{array}{cc}v & \mathrm{C}-\mathrm{O} \\
& \text { as } \\
\end{array}$ & $v \begin{array}{c}\mathrm{C}-\mathrm{O} \\
\mathrm{s}\end{array}$ & $\delta^{\mathrm{N}-\mathrm{H}}$ & $v^{\mathrm{C}-\mathrm{N}}$ & $v^{\mathrm{C}-\mathrm{H}}, v^{\mathrm{N}-\mathrm{H}}, v^{\mathrm{O}-\mathrm{H}}$ \\
\hline 1 & 2 & 3 & 4 & 5 & 6 & 7 & 8 \\
\hline $\mathrm{H}_{2} \mathrm{Glu}$ & 1695 & 1310 & 1630 & 1425 & 1545 & $1020-1080$ & $2800-2900$ \\
\hline \multicolumn{8}{|c|}{ The complexes of neodymium } \\
\hline Compound & $v \begin{array}{c}\mathrm{C}=\mathrm{O} \\
\mathrm{COOH}\end{array}$ & $\delta_{\mathrm{COOH}}$ & $\begin{array}{cc}\mathrm{C}-\mathrm{O} \\
\text { as }\end{array}$ & $v \quad \begin{array}{c}\mathrm{C}-\mathrm{O} \\
\mathrm{s}\end{array}$ & $\delta^{\mathrm{N}-\mathrm{H}}$ & $v^{\mathrm{C}-\mathrm{N}}$ & $v^{\mathrm{C}-\mathrm{H}}, v^{\mathrm{N}-\mathrm{H}}, v^{\mathrm{O}-\mathrm{H}}$ \\
\hline $\mathrm{Nd}(\mathrm{HGlu})_{3} \cdot 3 \mathrm{H}_{2} \mathrm{O}$ & & & $1550-1560$ & 1405 & & $1045-1080$ & $2500-3600$ \\
\hline $\mathrm{Nd}(\mathrm{HGlu}) \mathrm{Glu} \cdot 5 \mathrm{H}_{2} \mathrm{O}$ & & & $1550-1680$ & 1410 & & $1045-1080$ & $2500-3600$ \\
\hline Nd(HGlu)Glu & & & $1550-1660$ & 1410 & & $1045-1080$ & $29503100-3400$ \\
\hline $\mathrm{Nd}(\mathrm{HGlu})_{3} \cdot 7 \mathrm{H}_{2} \mathrm{O}$ & & & $1550-1670$ & 1410 & & $1040-1080$ & $2500-3600$ \\
\hline $\mathrm{Nd}(\mathrm{HGlu})_{3}$ & & & $1570-1660$ & 1420 & & $1045-1080$ & $2900-3300$ \\
\hline $\mathrm{Nd}(\mathrm{Glu}) \mathrm{Cl} \cdot 5 \mathrm{H}_{2} \mathrm{O}$ & & & $1554 \mathrm{~s}$ & $1408 \mathrm{~s}$ & & $1036 \mathrm{~m}$ & $\begin{array}{l}2782 \mathrm{~m} \\
2930 \mathrm{~m} \\
3158 \mathrm{~s} \\
3354 \mathrm{~s}\end{array}$ \\
\hline $\mathrm{Nd}(\mathrm{HGlu})_{3} \cdot 2 \mathrm{H}_{2} \mathrm{O}$ & & & $1556 \mathrm{~s}$ & $1408 \mathrm{~m}$ & & $\begin{array}{l}1034 \mathrm{~m}, \\
1076 \mathrm{~m}\end{array}$ & $\begin{array}{l}2404 \mathrm{~m} \\
2590 \mathrm{~m} \\
2782 \mathrm{~m} \\
2926 \mathrm{~m} \\
3080 \mathrm{~m} \\
3158 \mathrm{~m} \\
3384 \mathrm{~m}\end{array}$ \\
\hline $\mathrm{Nd}(\mathrm{Glu}) \mathrm{Cl} \cdot 6 \mathrm{H}_{2} \mathrm{O}$ & & & $1582 \mathrm{~s}$ & $1408 \mathrm{~m}$ & & $1076 \mathrm{~m}$ & $\begin{array}{l}2552 \mathrm{w} \\
2588 \mathrm{w} \\
2738 \mathrm{w} \\
2782 \mathrm{~m} \\
2856 \mathrm{~m} \\
2926 \mathrm{~m} \\
3080 \mathrm{~m} \\
3158 \mathrm{~m} \\
3386 \mathrm{~m}\end{array}$ \\
\hline \multicolumn{8}{|c|}{ The complexes of dysprosium } \\
\hline Compound & $v \begin{array}{c}\mathrm{C}=\mathrm{O} \\
\mathrm{COOH}\end{array}$ & $\delta_{\text {соон }}$ & $\begin{array}{cc}v \quad \mathrm{C}-\mathrm{O} \\
\text { as }\end{array}$ & $v \underset{\mathrm{s}}{\mathrm{C}-\mathrm{O}}$ & $\delta^{\mathrm{N}-\mathrm{H}}$ & $v^{C-N}$ & $v^{\mathrm{C}-\mathrm{H}}, v^{\mathrm{N}-\mathrm{H}}, v^{\mathrm{O}-\mathrm{H}}$ \\
\hline 1 & & & $\begin{array}{l}1632 \mathrm{~m}, \\
1666 \mathrm{~m}\end{array}$ & $1406 \mathrm{~m}$ & & & $\begin{array}{l}2502 \mathrm{w} \\
2598 \mathrm{w} \\
2624 \mathrm{w} \\
2666 \mathrm{w} \\
2784 \mathrm{~m} \\
2856 \mathrm{~m} \\
2926 \mathrm{~m} \\
2960 \mathrm{~m} \\
3050 \mathrm{~m} \\
3154 \mathrm{~m} \\
3352 \mathrm{~m}\end{array}$ \\
\hline
\end{tabular}




\begin{tabular}{|c|c|c|c|c|c|c|c|}
\hline \multicolumn{8}{|c|}{ End of Table 2} \\
\hline 1 & 2 & 3 & 4 & 5 & 6 & 7 & 8 \\
\hline 2 & & & $\begin{array}{l}1552 \mathrm{~m}, \\
1630 \mathrm{~m}, \\
1674 \mathrm{~m}\end{array}$ & & & $\begin{array}{l}1040 \mathrm{w}, \\
1080 \mathrm{~m}\end{array}$ & $\begin{array}{l}2502 \mathrm{~m} \\
2602 \mathrm{~m} \\
2624 \mathrm{~m} \\
2646 \mathrm{~m} \\
2722 \mathrm{~m} \\
2814 \mathrm{~s} \\
2860 \mathrm{~s} \\
3046 \mathrm{~s} \\
3142 \mathrm{~s} \\
3350 \mathrm{~s}\end{array}$ \\
\hline 3 & & & $\begin{array}{c}1552 \mathrm{~m}, \\
1584 \mathrm{~m}, \\
1628 \mathrm{~s}\end{array}$ & & & $\begin{array}{l}1040 \mathrm{~m}, \\
1080 \mathrm{~m}\end{array}$ & $\begin{array}{l}2502 \mathrm{~s} \\
2600 \mathrm{~m} \\
2624 \mathrm{~m} \\
2646 \mathrm{~m} \\
2806 \mathrm{~m} \\
3046 \mathrm{~s} \\
3132 \mathrm{~s} \\
3354 \mathrm{~s}\end{array}$ \\
\hline
\end{tabular}

N o te s: All the complexes isolated are X-ray amorphous.

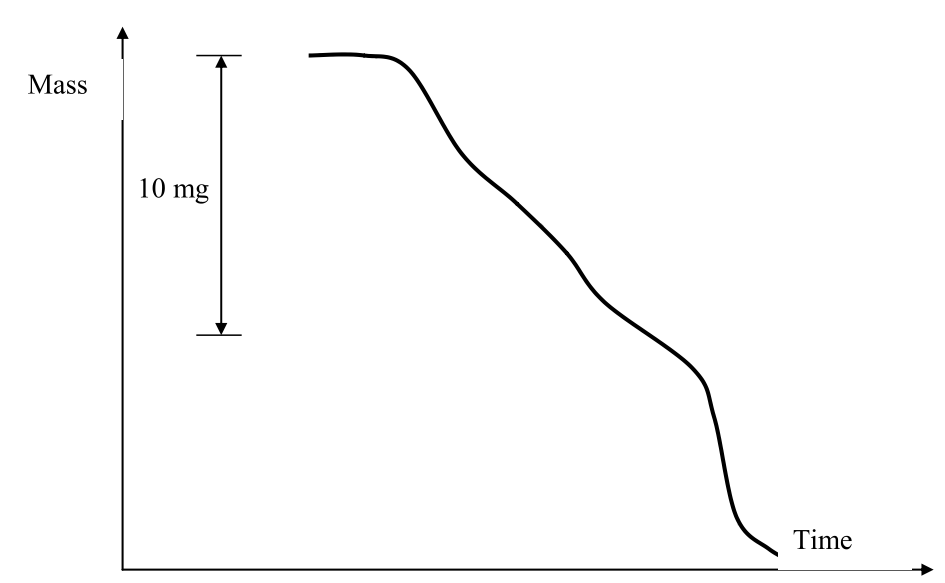

Fig. 3

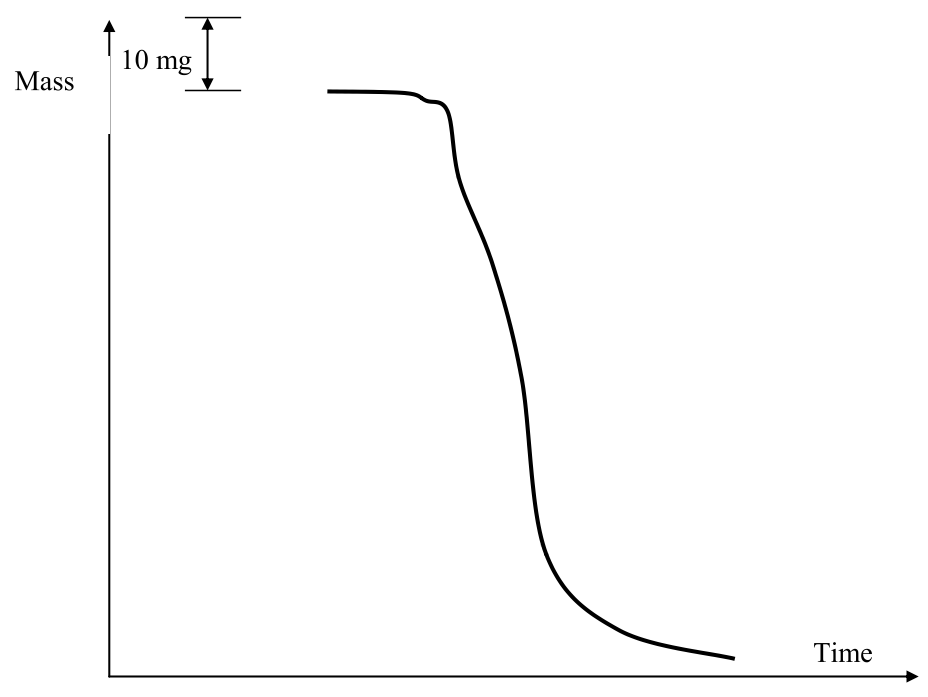

Fig. 4 
FTIR spectra of these compounds in the wavenumber region 400-4000 confirm generation of the complexes (lack of stripes belonging to glutamic acid, splitting and displacement of other stripes).

The results of physico-chemical analyses of the complexes of dysprosium allow us to make conclusions of insufficient chemical pureness of the complexes (stripes of ammonium chloride and glutamic acid in X-ray diffraction patterns). The complexes of dysprosium obtained in proportion of the initial substances $1: 2$ and 1:3 are sticky substances. Hence it can be supposed that they have polymeric structure. The results of thermal analysis of the complexes are presented in the Fig. 3-4 and in the Table 3.

Thermal analysis of the complexes of neodymium with glutamic acid

Table 3

\begin{tabular}{|c|c|c|c|c|}
\hline Compound & No. of the dehydration stage & Interval, ${ }^{\circ} \mathrm{C}$ & Mass decrease, $\%$ & $\begin{array}{c}\text { Mass decrease in moles } \\
\text { of } \mathrm{H}_{2} \mathrm{O}\end{array}$ \\
\hline \multirow{2}{*}{$\mathrm{Nd}(\mathrm{Glu}) \mathrm{Cl} \cdot 3 \mathrm{H}_{2} \mathrm{O}$} & 1 & $55-170$ & 8,3 & 1,8 \\
\cline { 2 - 5 } & 2 & $170-265$ & 5,6 & 1,2 \\
\hline \multirow{2}{*}{$\mathrm{Nd}(\mathrm{Glu}) \mathrm{Glu} \cdot 5 \mathrm{H}_{2} \mathrm{O}$} & 1 & $50-175$ & 8,9 & 2,6 \\
\cline { 2 - 5 } & 2 & $175-260$ & 8,4 & 2,4 \\
\hline \multirow{2}{*}{$\mathrm{Nd}(\mathrm{HGlu})_{3} \cdot 7 \mathrm{H}_{2} \mathrm{O}$} & 1 & $70-170$ & 9,8 & 3,9 \\
\cline { 2 - 5 } & 2 & $170-220$ & 7,9 & 3,1 \\
\hline \multirow{2}{*}{$\mathrm{Nd}(\mathrm{Glu}) \mathrm{Cl}^{2} \cdot 5 \mathrm{H}_{2} \mathrm{O}$} & 1 & $80-160$ & 2,5 & 0,6 \\
\cline { 2 - 5 } & 2 & $160-240$ & 11,0 & 2,5 \\
\cline { 2 - 5 } & 3 & $240-310$ & 44,5 & - \\
\hline \multirow{2}{*}{$\mathrm{Nd}(\mathrm{HGlu})_{3} \cdot 2 \mathrm{H}_{2} \mathrm{O}$} & 1 & $80-130$ & 1,2 & 0,2 \\
\cline { 2 - 5 } & 2 & $130-380$ & 3,5 & 0,7 \\
\cline { 2 - 5 } & 3 & $380-470$ & 1,7 & 0,3 \\
\hline
\end{tabular}

It can be said in conclusion that in spite of difficulties, which the studying such complexes cause, nowadays, when we have real possibilities for studying them, it is quite possible to reach significant success and clearness in studying many vital significant processes. Such complexes are of great importance in processes proceeding in biological systems.

\section{References}

1. Kriss E.E., Volchenskova I.I., Grigor'eva A.S. // Coordination compounds of metals in medicine. - Kiev: Naukova dumka, 1986. - P. 3-16, 194-196 (in Russian).
2. Zhichang L., Chiqing L., Kejun T. Synthesis and antitumor activity of lanthanum sulfate complex with glutamic acid // Zhongguo Yaowu Huaxue Zazhi. - 1999. - V. 9(1). - P. 13-15 (in Chinese).

3. Torres J., Kremer C., Kremer E., Pardo H., Suescun L., Mombru A., Dominguez S., Mederos A. Sm (III) complexation with $\alpha$-amino acids. X-ray crystal structure of [Sm2(Hala)4(H2O)6](ClO4)4(Cl)2 // Journal of Alloys and Compounds. - 2001. - V. 323-324. - P. 119-124.

4. Liangsheng Q., Yu X., Ying S., Jingyng S., Shenman G., Chongquan X., Chuncheng Z., Hong L. Growth and pyroelectric properties of Nd: DL-Ala:L-Glu:TGS crystals // Rengong Jingti Xuebao. - 1997. - V. 26(2). - P. 151-154 (in Chinese).

5. Shumei Z., Hong L., Chuncheng Z. Growth and pyroelectric property of TGS crystal // Harbin Ligong Daxue Xuebao. - 1998. - V. 3(5). - P. 81-84 (in Chinese). 


\section{Materials of Conferences}

\section{PREDICTION OF ISOVALENT SUBSTITUSHIONS OF PB ${ }^{2+}$ IN PBZR $_{3} \mathrm{O}_{4} \mathrm{~F}_{6}$ STRUCTURE}

Kuchina Y.V., Golubev A.M., Slyn'ko L.E.

Bauman Moscow state technical university, Moscow, e-mail: julia.kuchina90@gmail.com

The structure type $\mathrm{PbZr}_{3} \mathrm{O}_{4} \mathrm{~F}_{6}(a \approx 2 a$ (fluorite), $Z=8$, space group of symmetry $F m-3 m$ ) is derived from the structure type $\mathrm{KY}_{3} \mathrm{~F}_{10}$, which belongs to the group $A_{2} B_{6} X_{20-22}$ of family fluoritelike phases $\left\{A_{8-x} B_{6} C_{y} X_{n+2(y-x)}\right\}_{m}$ [1]. The feature of this family is the ability of iso- and heterovalent substitutions in the cation and anion sublattices, which offer the way to find new structures that can serve as a basis for creating materials with desired physical and chemical properties. The change of composition of chemical compounds within the unchanged structural type is associated with changes of the unit cell parameters and as a result reducing or increasing the energy density of the crystal lattice, which leads to the variation of some physical and chemical properties [2]. Modeling of crystal structures can significantly reduce the amount of experimental research in order to find promising new materials.

This article is described the options isovalent substitutions $\mathrm{Cd}^{2+}, \mathrm{Ca}^{2+}, \mathrm{Sr}^{2+}$ and $\mathrm{Ba}^{2+}$ cations of $\mathrm{Pb}^{2+}$ cations in the $\mathrm{PbZr}_{3} \mathrm{O}_{4} \mathrm{~F}_{6}$ structure. $\mathrm{Cd}^{2+}, \mathrm{Ca}^{2+}, \mathrm{Sr}^{2+}$ and $\mathrm{Ba}^{2+}$ cations are able to form structures belonging to the family of fluorite-like phases $\left\{A_{8-x} B_{6} C_{y} X_{n+2(y-x)}\right\}_{m}$. To estimate the possibility of the formation of new structures the bond valence method was used that is widely used in modern chemistry of inorganic ionic compounds [3]. According to this method, the sum of the bond valences of each ion in the structure is equal to the absolute value of the charge of this ion (oxidation state):

$$
|Z|=\sum s
$$

The simulation results of the basic crystal structure $\mathrm{PbZr}_{3} \mathrm{O}_{4} \mathrm{~F}_{6}$ testify to the correctness of this concept [4]. The relative deviations of the calculated structure parameters from experimental parameters did not exceed $2 \%$.

The coordinates of the atoms of the structure $\mathrm{PbZr}_{3} \mathrm{O}_{4} \mathrm{~F}_{6}$ were used as a starting model for calculations. When modeling structures proposed in [5] function $\Phi$ was minimized, taking into account not only the cation-anion interaction, but anion-anion repulsion too:

$$
\Phi=\sum\left(\Delta Z_{\mathrm{i}}\right)^{2}+\sum\left[B /\left(d_{X-X}\right)^{12}\right] / 2,
$$

where $\Delta Z$, the difference between the tabulated and calculated ion charge, $d_{X-X}$ - the anion-anion distance, $B$-empirical constant. Our previous studies have shown that the cation-cation interactions can be neglected, since their inclusion does not affect the final result.

Calculation of the bond valence was executed by the exponential dependence of $s=\exp \left(\left(R_{\mathrm{o}}-d\right) / b\right)$ [3], where $s-$ the cation-anion bond valence, $R$ - empirical parameter that characterizes this relationship, $d$ - the interatomic distance, $b$-empirical constant equal to $0,037 \mathrm{~nm}$. The correctness of the obtained model of the structure was evaluated by the global instability index GII [3]:

$$
G I I=\left[\sum\left(d^{2} / N\right)\right]^{1 / 2},
$$

where $d$ is a difference between the tabulated and calculated charge for $N$ ions in the independent part of the unit cell. The values of the GII index less than 0,1 indicate the stability of the crystal structure.

The results of the simulation indicate the stabil-

\begin{tabular}{|c|c|c|c|c|c|c|c|c|c|}
\hline \multirow[t]{2}{*}{ Structure } & \multirow[t]{2}{*}{$a, \mathrm{~nm}$} & \multicolumn{3}{|c|}{ Coordinates of the atoms } & \multirow{2}{*}{$\begin{array}{c}\text { Index } \\
\text { GII }\end{array}$} & \multicolumn{4}{|c|}{ Absolute ion charge } \\
\hline & & $x(\mathrm{Zr})$ & $x(\mathrm{O})$ & $y(\mathrm{~F})$ & & $\mathrm{Zr}^{4+}$ & $A^{2+}$ & $\mathrm{O}^{2-}$ & $\mathrm{F}^{1-}$ \\
\hline $\mathrm{CdZr}_{3} \mathrm{O}_{4} \mathrm{~F}_{6}$ & 1,0792 & 0,2200 & 0,1226 & 0,1662 & 0,140 & 3,87 & 1,60 & 1,94 & 0,91 \\
\hline $\mathrm{CaZr}_{3} \mathrm{O}_{4} \mathrm{~F}_{6}$ & 1,0715 & 0,2228 & 0,1232 & 0,1663 & 0,006 & 3,99 & 1,98 & 2,00 & 1,00 \\
\hline $\mathrm{SrZr}_{3} \mathrm{O}_{4} \mathrm{~F}_{6}$ & 1,0896 & 0,2256 & 0,1143 & 0,1650 & 0,005 & 3,99 & 2,00 & 2,00 & 1,00 \\
\hline $\mathrm{BaZr}_{3} \mathrm{O}_{4} \mathrm{~F}_{6}$ & 1,1232 & 0,2172 & 0,1104 & 0,1654 & 0,246 & 3,59 & 2,23 & 2,08 & 0,79 \\
\hline
\end{tabular}
ity of structures $\mathrm{CaZr}_{3} \mathrm{O}_{4} \mathrm{~F}_{6}$ and $\mathrm{SrZr}_{3} \mathrm{O}_{4} \mathrm{~F}_{6}$ (Table).

The simulation results of the crystal structures $A \mathrm{Zr}_{3} \mathrm{O}_{4} \mathrm{~F}_{6}$.

The theoretically calculated absolute values of the charges of the ions for these structures don't differ from the generally accepted values. The global index of instability GII has a small value of about 0.01 , which indicates a possibility of their existence. The obtained interatomic distances are in the typical range for crystal structures containing these ions. The constructed of six square antiprisms $\left\{\mathrm{ZrO}_{4} \mathrm{~F}_{4}\right\}$ structure-forming fragments - clusters $\left\{\mathrm{Zr}_{6} \mathrm{O}_{24} \mathrm{~F}_{12}\right\}$ in structures $\mathrm{CaZr}_{3} \mathrm{O}_{4} \mathrm{~F}_{6}$ and $\mathrm{SrZr}_{3} \mathrm{O}_{4} \mathrm{~F}_{6}$ don't differ from similar clusters $\left\{\mathrm{Zr}_{6} \mathrm{O}_{24} \mathrm{~F}_{12}\right\}$ in the basic structure $\mathrm{PbZr}_{3} \mathrm{O}_{4} \mathrm{~F}_{6}$ (Figure). 


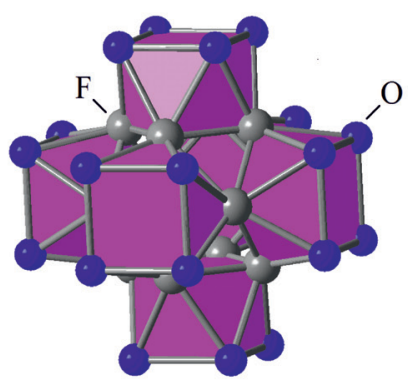

a)

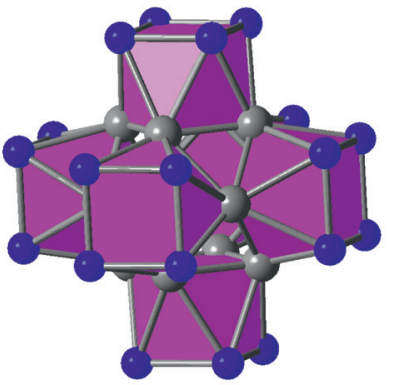

b)

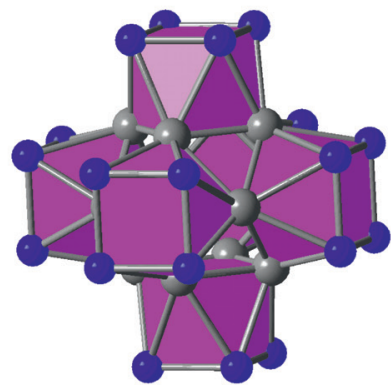

c)

Clusters $\left\{\mathrm{Zr}_{6} \mathrm{O}_{24} \mathrm{~F}_{12}\right\}$ in the structures $\mathrm{CaZr}_{3} \mathrm{O}_{4} \mathrm{~F}_{6}(\mathrm{a}), \mathrm{SrZr}_{3} \mathrm{O}_{4} \mathrm{~F}_{6}(\mathrm{~b})$ and $\mathrm{PbZr}_{3} \mathrm{O}_{4} \mathrm{~F}_{6}$ (c)

The $\mathrm{CdZr}_{3} \mathrm{O}_{4} \mathrm{~F}_{6}$ and $\mathrm{BaZr}_{3} \mathrm{O}_{4} \mathrm{~F}_{6}$ structures are characterized by high values of the global instability index more than 0.1 for the first structure and more than 0.2 for the second structure, that indicate the inability to obtain these structures. The theoretical values of the charges of the ions forming the $\mathrm{CdZr}_{3} \mathrm{O}_{4} \mathrm{~F}_{6}$ and $\mathrm{BaZr}_{3} \mathrm{O}_{4} \mathrm{~F}_{6}$ structures differ substantially from the conventional values (Table).

Thus, the simulation of crystal structures $A \mathrm{Zr}_{3} \mathrm{O}_{4} \mathrm{~F}_{6}(A=\mathrm{Cd}, \mathrm{Ca}, \mathrm{Sr}, \mathrm{Ba})$ belonging to the structural type $\mathrm{PbZr}_{3} \mathrm{O}_{4} \mathrm{~F}_{6}$ indicates the possible existence of crystal structures $\mathrm{CaZr}_{3} \mathrm{O}_{4} \mathrm{~F}$ and $\mathrm{SrZr}_{3} \mathrm{O}_{4} \mathrm{~F}_{6}$.

\section{References}

1. Golubev A.M. Cluster theory for fluorite-like fluorides containing anionic cuboctahedra. // International Symposium on Inorganic Fluorides: Chemistry and Technology: Book of Abstracts / Editor: V.N. Mitkin, R.V. Ostvald; Tomsk Polytechnic University. - Tomsk: TPU Publishing, 2014. - P. 53.
2. Zuev V.V. Constitution, properties of minerals and structure of the Earth (energy aspects). - SPb.: Nauka, 2005. - 402 p. (in Russia).

3. Brown I.D. Recent Developments in the Methods and Applications of the Bond Valence Model // Chem. Rev. - 2009. V. 109. - № 12. - P. 6858-6919.

4. Kuchina Yu.V. Application of the BVS method for modeling crystal structure $\mathrm{PbZr}_{3} \mathrm{O}_{4}$. // Mendeleev - 2014. Bioorganic and medicinal chemistry. Organometallic and coordination chemistry. Modern chemical catalysis and simulation of chemical processes. VIII All-Russian conference with international participation of young scientists in chemistry. Abstracts. $-\mathrm{SPb}$, 2014. - P. 187-188. (in Russia).

5. Golubev A.M., Tatianina I.V., Gorjacheva V.N., Berezina S.L., Shapoval V.N. Simulation crystalline structures $\mathrm{A}(\mathrm{III})_{2} \mathrm{~B}(\mathrm{IV})_{2} \mathrm{O}_{7}$, and $\mathrm{A}(\mathrm{II})_{2} \mathrm{~B}(\mathrm{~V})_{2} \mathrm{O}_{7}$ of the pyrochlore family. Modern science and humanitarian problems. Proceedings. M.: "Logos", 2005. - P. 177-183. (in Russia).

The work is submitted to the International Scientific Conference "Computer modeling in science and technology", Dominican Republic, December, 17-27, 2014 came to the editorial office on 10.11.2014. 


\title{
RANGE OF LINGUISTIC UNITS USING
}

\author{
Kapalbekov B.S.
}

Institute of the State Language Development,_Almaty, e-mail: baian_80@mail.ru

Every language unit is marked by peculiar to it primary function, associated with its central meaning in the language system and considered as individual type. At the same time, any linguistic unit while using in the speech takes a new meaning, and becomes multivalent. Its additional meanings can be observed from possibility of using in varied positions while speaking.

Keywords: linguistic, primary function, meanings

The meaning raised as a result of using (RU), first of all, is formed from internal possibility of the language unit using (PU), and second, impacted by surrounding environment, or other words, by other language units of Syntagma composition as well as various factors outside the language system. Speaking conditionally, if to look at the clock as a complex system, constituting many interrelated working parts, it is obvious that the failure of any working part (e.g. spring) out of this set will result in loss of usability for a whole system, or other words its dysfunction.

The same can be observed in the language system. It's known that if to take out some linguistic units from the particular text in a whole, for example, the person indicators, the text, left with no possibility for specific purpose using (ex. communicative, aesthetic) loses its informational meaning.

Whatsoever the science we would take, there is always the result of using, arising from the purpose of using. For example, the circulatory system, studied by medicine and other natural sciences is a result of activity of the heart.

Owing to this process, the heart supplies system with viability, constituting a part of it, and preserving it. If however, refer to using in linguistics, this would suggest an idea of a role, mission and purpose of using of any language mean.

Each fulfilling goal, first of all, will be at the level of possibility. It means that the goal transforms into achieved result only if there is an opportunity to accomplish such purpose (if applicable).
Consequently, the very using includes the possibility of using (PU) and the result of using (RU) [1, p. 304]. In our opinion, there is a range of using along with possibility of language means using. It seems that in the term the function-potency pointed out by A.V. Bondarko the possibility and the range of using are becoming one.

Yet based on the analysis of the material of the Kazakh language we think that it is correct to study them separately as two borderlines of language means. If possibility of using is a general property of the language means, the range of using is derived from its private property.

Every language unit is polysemous but in traditional grammar it is defined only at the level of the system which it belong to, and the aspect of its polysemanticism is not entirely disclosed.

For example, the verbal participles as a functional type of the verb are described at the level of morphology, and are given passing mention to their participation in producing tense forms and some syntactic functions.

This can be called an initial level of acquaintance with the language system and acquaintance with the language. Since this description is based on the principle "from the form to a meaning", a prime focus is drawn to unit's original meaning $(\mathrm{OM})$. There is a definition given by A. Baytursynov for verbal participles: "the short form of paired verbs which uttered first is called an verbal participle".

For example, "the first words in expressions zhaza ber, karap tur, zhurip keldi are verbsparticiples" [2, p. 245]. This meaning is OM of the verbal participle determined at the first level with the form driven. Refer to the Table 1:

\begin{tabular}{|l|l|l|l|}
\hline \multicolumn{1}{|c|}{ T } & \multicolumn{1}{|c|}{2} & \multicolumn{1}{c|}{ Table 1 } \\
\hline $\begin{array}{l}\text { Linguistic unit and its } \\
\text { original meaning (OM) } \\
\text { Verbal participles }\end{array}$ & $\begin{array}{l}\text { Possibility of using } \\
\text { (PU) }\end{array}$ & \multicolumn{1}{|c|}{ Range of using (RnU) } & \multicolumn{1}{c|}{$\begin{array}{c}\text { The result of using } \\
\text { (RzU) }\end{array}$} \\
\hline $\begin{array}{l}\text { Requires the closing } \\
\text { verb }\end{array}$ & $\begin{array}{l}\text { At all levels is used } \\
\text { in the subordinated } \\
\text { meaning. }\end{array}$ & $\begin{array}{l}\text { a) formation of tense forms } \\
\text { b) formation of compound } \\
\text { verbs } \\
\text { c) formation of similar parts } \\
\text { g) is adjunct } \\
\text { d) formation of subordinate } \\
\text { command of complex structures }\end{array}$ & $\begin{array}{l}\text { a) formation of FSF } \\
\text { (functional semantic } \\
\text { field) temporality } \\
\text { 6) formation of FSF as- } \\
\text { pectuality formation of FSF tax- } \\
\text { is etc. }\end{array}$ \\
\hline
\end{tabular}


Listed in the second and third columns of Table 1 the PU and the RnU linguistic units in direction "from the form to the meaning", but respectively to a principle of using are determined by initial methods of functional grammar, described as a group.

There studies were conducted in the Kazakh linguistics on such area concerning verbal participles forms. There not only paradigmatic line of $\mathrm{RnU}$ specified in Table 1 is determined but syntagmatic chain [2, p. 736] as well. We'll try to define the PU and the RnU of separate linguistic units by making an analysis of verbal participles forms:

Suffixes of verbal participles take part in producing adverbial modifier of manner, reason, purpose and time: khatulana shykhty (modifier of manner), sagynyp keldim (cause), aytkhaly keldim (purpose), tan' ata ketti (time). Additionally, the suffixes of verbal participles perform the function of creating similar adjuncts in the sentence. In summary, it can be shown by the following scheme.

\begin{tabular}{|l|l|l}
\hline $\begin{array}{l}\text { Adverbial function of verbal } \\
\text { participles }\end{array}$ & 1 & a,b,c,d,e \\
\cline { 1 - 2 } & Syntagmatic area \\
\hline
\end{tabular}

Table 2

a) Formation of adverbial modifier of manner

b) formation of adverbial modifier of cause;

c) formation of adverbial modifier of purpose;

g) formation of adverbial modifier of time;

d) formation of similar adverbial modifier.

This is one part of possibilities of verbal participles forms using. In other words, it is an indicator of some part of the using paradigm. From following analysis below, we will make sure that the range of using of these forms is extremely wide.

Initial stage of combinations move, including adverbial adjuncts expressed by verbal participles forms, to compound verbs are per- formed by simple compound verbs. They relate to the second function of verbal participles suffixes in the language after performing the function of verbal participle in the sentence. Therefore, they cannot be put in one level with adverbial function. For this reason, we have identified them in a separate paradigmatic line. Summing up, it can be shown by the following scheme:

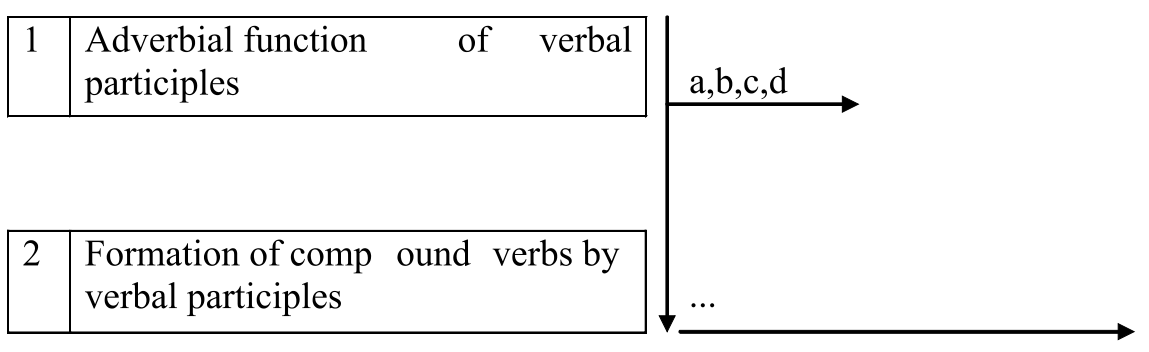

Table 3

a) A simple compound verb - Sen baryp kel.

b) Analytical verb - Siz muny aita kormeniz.

c) Descriptive verb - Koreyin dep baryp edim.

d) Fixed verb - Olar khol khusyryp otyr.

The range of verbal participles using can be seen under their using as similar predicates.

The similar predicates formed by verbal participles forms, is difficult to distinguish. Sometimes they are like members of the adverbial parts. By the fact that two verbs are implying an action appearing as a separate process, they can be related to the similar predicates.
The similar predicates formed by verbal participles make a phenomenon that has arisen from the goal of abridged expression of a thought. If the predicates will have separate subjects in a sentence, formed by verbal participles then such sentences from simple become complex. Thus, based on the adverbial adjuncts of simple sentence formed by the verbal participles by means of derivative relations have developed such types 
of subordinated clauses, as final clause, clause of cause, clause of time and clause of manner.

One might assume that on the basis of similar predicates formed by the ver- bal participles suffixes, sub clauses have emerged that do not fall under the principal clause in terms of sense. Refer to a Table 4:

\begin{tabular}{|l|ll}
\hline 1 & $\begin{array}{l}\text { Adverbial function of verbal } \\
\text { participles }\end{array}$ \\
\hline
\end{tabular}
\begin{tabular}{|l|l|}
\hline 2 & $\begin{array}{l}\text { Formation of comp ound verbs by } \\
\text { verbal participles }\end{array}$ \\
\hline
\end{tabular}

\begin{tabular}{|l|l|}
\hline 3 & $\begin{array}{l}\text { Formation of similar predicates by } \\
\text { verbal participles }\end{array}$ \\
\hline
\end{tabular}

\section{Table 4}

As the Table 4 shows syntagmatic function of verbal participles is small, these forms at the first paradigmatic lines are involved in the formation of such variety of compound verbs, as compound verbs and all other four types. And since the linguistic nature of similar predicates in the Kazakh linguistics is still understudied, there is yet lack of way to show the syntagmatic range of this line using.

The fourth line of the range of using the verbal participles implies their participation in the formation of complex structures. Comparing to the third line there a great range of using syntagmatic line is observed. For example, it is known that the verbal participles suffixes are involved into forming six types of subordinating structures (mode of action, cause, time, purpose, consistency and concessiveness).

Though, the following Table 5 is aimed to demonstrate how a lower-level units are transforming to the base for complex structures formation.

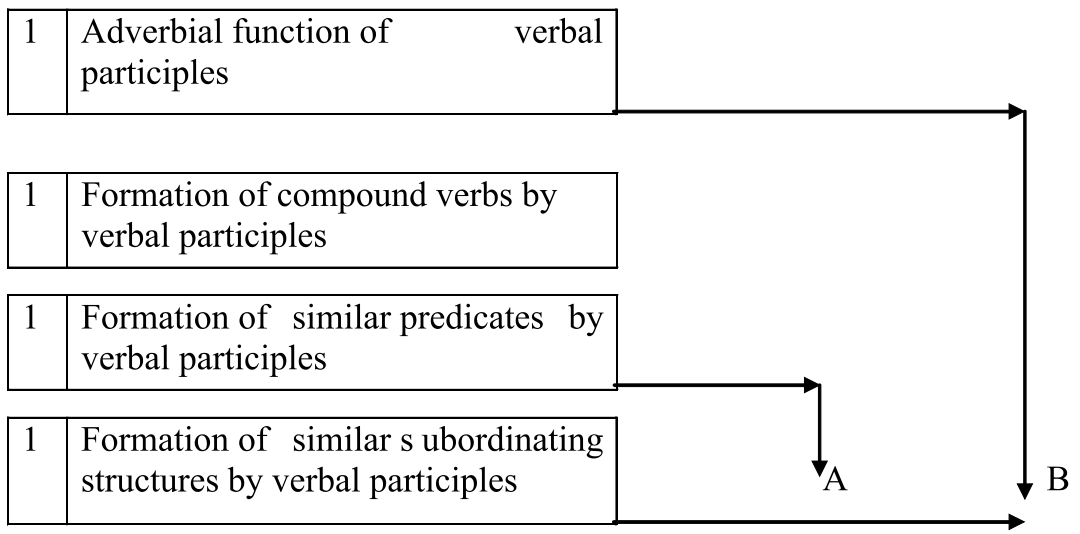

Table 5

As the Table shows, although formed similar predicates (A) in 3 rd paradigmatic line by the verbal participles are subordinated as for formal side, it became a base for forming sentences, that are free from the principal part as for sense bearing. Regarding verbal participle functions in 1st paradigmatic line (B) the subordinated second part of the pair are subject- ed to the principal part by both meaning and formally and acts out as one of its members, which in turn became the base for the complex sentences formation.

It would be wise to conduct a study in the area of any linguistic units so that to determine the range of language units using. According to observations of scientists, the formocentrical 
area, that is, "from formal indicator to a function" is the most essential step to move to the second level of functional grammar, that is, a method of research "from function to a formal indicator (means)" [3, p. 3$]$.

Not only the above verbal participles forms, but each functional unit has a specific range of using, unlike to others. Range of using is built from a set of individual usages, typical to that unit. The question arises: where from originates or how forms the range of using and the possibility of using? As pointed out by scholars, designated for this area exploration, this phenomenon comes out from using the certain linguistic units with adaptation to the appropriate environment.
The article deals with the concept of functions as assignment, destination and the purpose of their use as an example of verbal participles.

Each assignment (any purpose), first of all appears as a possibility, ability, and then as the achieved result. Based on this the Tables have demonstrated a potential of the verbal participle of the Kazakh language.

\section{References}

1. Bondarko A.V. The theory of meaning in the system of functional grammar. - Moscow, 2002. - $736 \mathrm{p}$.

2. Khapalbekov B.S. "Formation of species of subordinated verbal participles" (Candidate thesis.). - Almaty, 2000. - 144 p.

3. Shelyakin M.A. "Functional grammar of Russian language". - Moscow, 2001. -287 p. 


\title{
SIMPLE KELVIN EQUATION APPLICABLE IN THE CRITICAL POINT VICINITY
}

\author{
Valeev A.A.
}

Kamyshin Technological Institute of Volgograd State Technical University, Kamyshin, e-mail:waleev@mail.ru

\footnotetext{
New simple form of the Kelvin equation is offered that applies near the gas-liquid transition critical point.
}

Keywords: Kelvin equation, critical point, phase transition, nano-structured materials

Well known form of the Kelvin Equation [1, 2]

$$
\frac{\tilde{p}_{s a t}}{p_{s a t}}=\exp \left(-\frac{\mu}{\rho_{L} R T} \frac{2 \sigma}{r}\right)
$$

has been proved to work excellent for the phase equilibrium of rare gas and liquid systems, the ones it was originally designed for. Here $p_{\text {sat }}$, $\tilde{p}_{\text {sat }}$ are the saturated vapor pressures against a plain surface and a meniscus with effective curvature radius $r$, respectively, the latter accounting for such effects as the adsorption at the pore wall. Number " 2 " stays for spherical geometry of the meniscus. It should be replaced by " 1 " in the case of the cylindrical geometry. $\mu$ is the molar mass of the substance in use, $\rho_{\text {r }}$ is the liquid phase density, $R$ is the universal gas constant. Quite often, this equation is misused when applied to high-presser gases and to liquids at near-critical temperatures.

To account for the gas's nonideality, another equation [3] was developed:

$$
\frac{\tilde{f}_{\text {sat }}}{f_{\text {sat }}}=\exp \left(-\frac{\mu}{\rho_{L} R T} \frac{2 \sigma}{r}\right)
$$

where $f$ is the replacement of the pressure by the fugacity. In the next paragraph, it will be shown that this equation, as well as those obtained in [4], does not work quite well near the critical point and the replacement will be presented.

\section{Kelvin equation from scratch}

We consider a liquid-gas equilibrium system divided by a plain surface. Now we can put down the change in the Gibbs energy for each phase:

$$
d G_{i}=d \mu_{i} n_{i}=-S_{i} d T_{i}+V_{i} d p_{i}+\mu_{i} d n_{i},
$$

where $i$ denotes the phase that can be either $G$ or $L . \mu_{i}, n_{i}, S_{i}, T_{i}, V_{i}, p_{i}$ are chemical potential, amount of substance, entropy, temperature, volume and pressure of the phase $i$, respectively. Taking into account that both phases are in the state of thermodynamical equilibrium, we can put:

$$
T_{G}=T_{L} \equiv T, \quad \mu_{G}=\mu_{L} \equiv \mu .
$$

Generally speaking, $p_{G} \neq p_{L}$, due to additional pressure by the curved surface tension. The eq. (3) will take the following form:

$$
d G_{i}=d \mu n_{i}=-S_{i} d T+V_{i} d p_{i}+\mu d n_{i} .
$$

Now we can put down the change in the chemical potential:

$$
d \mu=d\left(G_{i} / n_{i}\right)=-s_{i} d T+v_{i} d p_{i},
$$

where $s_{i}, v_{i}$, are the molar entropy and the molar volume, respectively. Now we can see that

$$
(d \mu)_{T, n_{i}}=v_{i} d p_{i} .
$$

Taking into account that $p_{L}=p_{G}-2 \sigma / r$, we can put

$$
(d \mu)_{T, n_{i}}=v_{G} d p_{G}=v_{L} d\left(p_{G}-2 \sigma / r\right) .
$$

Omitting $v_{L} d p_{G}$ term is what has been done to obtain the eq's (1), (2) and the analogous equations in [4], because the gas phase there has been considered dilute. This is not our case, because we operate in the critical point vicinity, i.e. $v_{L}$ is comparable with $v_{G}$. Integrating the eq. (8)

$$
\int_{p_{s a t}}^{\tilde{p}_{s a t}}\left(v_{G}-v_{L}\right) d p_{G}=-v_{L} 2 \sigma / r
$$

we obtain approximate equation

$$
\left(v_{G}-v_{L}\right)\left(\tilde{p}_{s a t}-p_{s a t}\right) \approx-v_{L} 2 \sigma / r,
$$

which can be used if $v_{G}-v_{L}$ does not change significantly within interval $\left(\tilde{p}_{\text {sat }} ; p_{\text {sat }}\right)$.

Finally, we have

$$
\tilde{p}_{s a t}-p_{s a t} \approx-\frac{v_{L}}{v_{G}-v_{L}} 2 \sigma / r=-\frac{\rho_{G}}{\rho_{L}-\rho_{G}} 2 \sigma / r,
$$

where $\rho_{G}$ is the gas phase density.

Now we can rewrite eq. (8) in the following form

$$
(d \mu)_{T, n_{i}}=v_{L} d p_{L}=v_{G} d\left(p_{L}+2 \sigma / r\right) .
$$


Integrating it we obtain

$$
\int_{p_{s a t}}^{\tilde{p}_{\text {sat }}^{L}}\left(v_{L}-v_{G}\right) d p_{L}=v_{G} 2 \sigma / r,
$$

where $\tilde{p}_{\text {sat }}^{L}$ is the pressure of the liquid phase in equilibrium with the saturated vapor (both divided by the curved meniscus).

$$
\left(v_{L}-v_{G}\right)\left(\tilde{p}_{\text {sat }}^{L}-p_{\text {sat }}\right) \approx v_{G} 2 \sigma / r,
$$

Now we can write

$$
\tilde{p}_{s a t}^{L}-p_{s a t} \approx-\frac{v_{G}}{v_{G}-v_{L}} 2 \sigma / r=-\frac{\rho_{L}}{\rho_{L}-\rho_{G}} 2 \sigma / r .
$$

\section{Conclusions}

The eq. (11) (along with the eq. (14) and the eq's (9), (12) in the integral form) is the new form of the Kelvin equation that applies near the gas-liquid transition critical point. It can be helpful in researches of nano-structured materials. It should be applied carefully, due to the geometry dependence of the surface tension.

\section{References}

1. Thomson W. On the Equilibrium of Vapour at a Curved Surface of Liquid, Proc. Roy. Soc. Edinburgh, 7 (1870) 63-68.

2. Thomson W. On the Equilibrium of Vapour at a Curved Surface of Liquid, Philosophical Magazine Series 4, 42 (282) (1871) 448-452.

3. Gregg S.J., Sing K.S.W., Adsorption, Surface Science and Porosity, Academic Press, New York, 1982.

4. Parry A.O., Evans R. Universal fluctuation-induced corrections to the Kelvin equation for capillary condensation, J. Phys. A: Math. Gen. 25 (1992) 275-284. 


\section{Short Reports}

THE DYNAMICS OF THE BIOLOGICAL PRODUCTIVITY OF BIOMES TUVA

\author{
Sambuu A.D.
}

Tuvinian Institute for the exploration of natural resources $S B R A S$;

Tuvinian state university Republic of Tuva, Kyzyl,e-mail:sambuu@mail.ru

Under the human activity is a significant part of the natural biomes replaced anthropogenic: crops, tree plantations and gardens, as well as man-made ecosystems.

Vegetation as a self-replicating resource biosphere is the component that captures solar energy and produces organic matter. The use of vegetation as a food is the Foundation of life and the development of other self-replicating resources, including humans. It presents a huge number of species composing the community and biomes.

The objective monitoring of the biological productivity of major biomes composing the vegetation of Tuva. In the present work for the first time the analysis of its dynamics and the distribution between major biomes of Tuva, the removal of vegetable matter and receipt of plant residues in the soil.

Materials and methods of research. The productivity of ecosystems reflects the biological potential of the system and is characterized by two parameters - the stock of phytomass and net primary production (NPP), i.e. the quantity of organic matter produced by green plants per unit of time (month, year) per unit area $\left(\mathrm{m}^{2} \mathrm{ha}\right)$ [1].

Our own studies on the productivity of ecosystems, in particular, the dynamics of stock biomass, net primary production, also the removal of vegetable matter and receipt of plant residues in the soil were carried out in different biomes Tuva from 1996 to 2009.

Results of research and their discussion. The Republic of Tuva is located in the South of Russia, in the Central part of the Asian continent. Mountain hollows relief of the Republic defines within it a complex combination of bioclimatic conditions, uniqueness and heterogeneity of soil and vegetation cover.

The climate is sharply continental. Features a short but hot summers, long and snowy winter, prolonged droughts. The average January temperature ranges from $-28^{\circ} \mathrm{C}$ to $-35^{\circ} \mathrm{C}$, July $15-20^{\circ} \mathrm{C}$, the snow depth is 10-20 see According to the scheme agroclimatic zoning of the territory of the Republic is characterized by insufficient and poor wetting (GCT is 0,4$)$, where in the basin the average annual rainfall of $250-300 \mathrm{~mm}$ of rain in the mountains $-700 \mathrm{~mm}$ Under the influence of climatic conditions in the river valleys and lowlands developed Chernozem leached and podzolized, within the steppe inter-mountain basins-a group of soils in the steppe and dry steppe soil is dark brown and black soils of the southern and South of the Republic in the area with extremely high moisture deficit are formed a series of soils in the dry steppe and desert-steppe soil, mostly chestnut and light chestnut [2].

For research conducted structuring of landscape zones, biomes and types of land use Tuva. As a landscape zones: taiga, forest-steppe, steppe, mountain landscapes and river valleys (figure). Biomes are defined by vegetation type and include forests, grasslands (steppes, meadows, and grassy marshes), mountain ecosystems (talus, cliffs, open grouping of vegetation, tundra). Types of land use include: crops, hay and pasture, intensively managed forests, disturbed lands - Gary, cutting, ravines, anthropogenic agglomerates - cities, towns, roads and other.

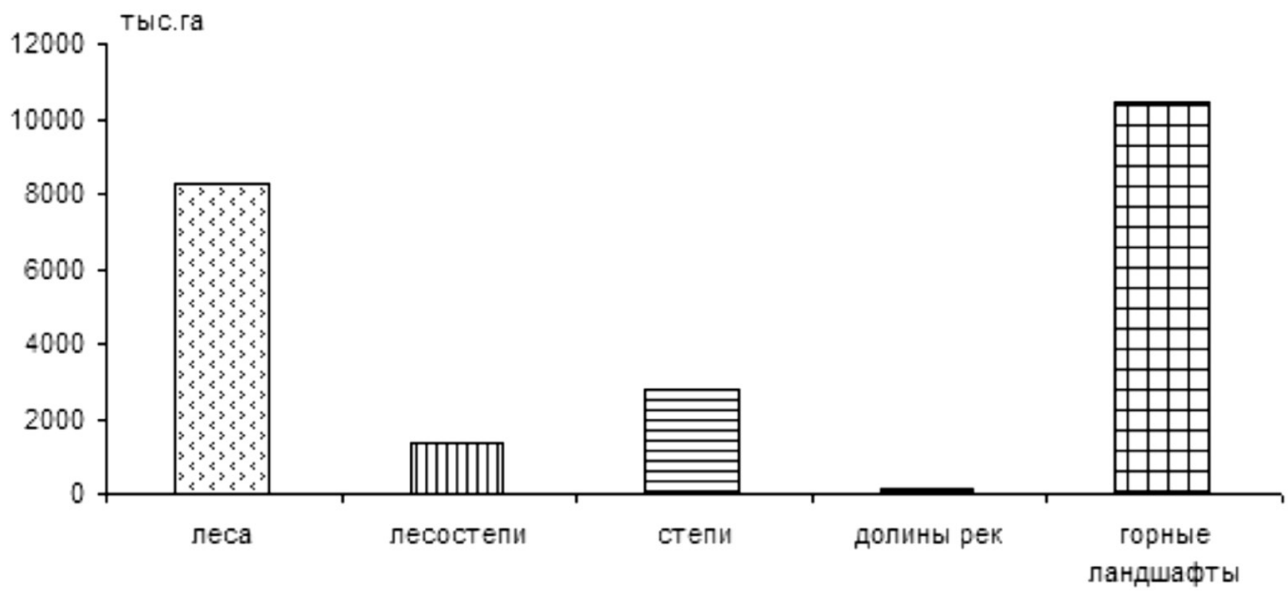

The structure of the vegetation cover of Tuva 
The total area of Tuva is 170,5 thousand $\mathrm{km}^{2}$. As in other areas of the mountains of southern Siberia, on the territory of Tuva vegetation obey the laws of altitudinal zonation with a well-marked mountain, the mountain and steppe zones.

Tuva is an old agricultural areas, because even in ancient times (from III century BC), its territory was inhabited by pastoral tribes, focusing primarily in the intermountain basins, river valleys, the most favorable for development of cattle breeding and agriculture. For millennia, the economic impacts to vegetation gradually increased in two main areas: the destruction of indigenous vegetation by changing the grass under the influence of grazing and ploughing. And since 1940 the replacement of natural ecosystems into agricultural lands leads to changes in their productivity.

Stocks of biomass, mortmass and products

In the process of producing biota, quantitative expression of which is net primary production, creates not only a new phytomass, but also consumes carbon dioxide and released oxygen. In this regard, the stock of phytomass, mortmass and value of production estimated for the territory of Tuva, characterize its action potential.

Mountain the face of the Republic determines its phytomass and distribution of the latter between biomes. Mountainous landscapes, including mountain tundra, dwarf birch, an open grouping of plants, constitute $22 \%$ of the territory of the Republic. All these ecosystems have low phytomass and production. Their contribution to the phytomass is $3.5 \%$, in mortmass much more $-16 \%$ and in production $-6 \%$.

The main area of the biome of the Republic of forests, which occupy $52 \%$ of the area of the Republic. Grassy ecosystems is much more than agricultural, industrial and residential landscapes in last place, occupying only $0.3 \%$ of the area of the Republic.

Forest vegetation of Tuva dedicated to mountain elevations and consist mainly of Siberian larch and cedar, which occupy and 47,1 44,7\% of forest area. Total wood reserves are estimated at 1090,85 million $\mathrm{m}^{3}$, of which the share of Siberian larch has 51,8 and cedar $-43,1 \%$. Forest lands constitute $95 \%$ of phytomass and $72 \%$ mortmass. In the product composition, the share of forests is much less - only $46 \%$.

A small area (24\%) are in the grasslands - grasslands in the valleys, subalpine and Alpine meadows in the mountains. The density of the phytomass of grass ecosystems reaches $4.1 \mathrm{t} / \mathrm{ha}$, due to the high stock of living underground organs of plants meadow and real steppes and Alpine meadows. The low density of biomass is due to the fact that the main type of virgin grassland ecosystems in Tuva - dry and desert steppes, phytomass which is significantly lower than the biomass of meadow steppes. High density mortmass grassy ecosystems $-5,5 \mathrm{t} /$ ha due to deposition in the soil of a large number of dead decayed roots and rhizomes. High and products are herbal ecosystems, constituting $48 \%$ of the NPP of the vegetation cover of the Republic.

Very small area of agricultural lands (1,5\%), which explains the very low contribution of this biome in the phytomass and production. The phytomass of agrocenoses basically form a grain and fodder crops, industrial crops and vegetables occupy a small area. Inventories mortmass one and a half times lower than stock biomass. The contribution of forests to mortmass below, and grassy ecosystems is higher than in the phytomass.

\section{Conclusions}

As a result of monitoring the various biomes of Tuva revealed that they differ in size, climate and landscape structure. 17,000 hectares of the total area of the Republic 8278 thousand ha are forest, 1355 forest steppe and - 3298 steppe zone. Therefore, they have different values and phytomass and production, also, these figures do not correlate with the area of the zones.

No direct proportion between the area on the one hand, phytomass and production on the other hand is associated with various biom structure zones. The largest stock of phytomass in the first place is determined by the area of forests of the Republic. The main type of transformation here is characterized by a small area of intensively managed plantations, deforestation and fires, and employed anthropogenic agglomerates - cities, towns, roads, mining, industrial facilities and other. The value of products is also not related to the total area of the zones and depends on the area of grass ecosystems, characterized by the highest among the existing in Tuva ecosystem products. The main producers are grassy ecosystems, forming $48 \%$ NPP, the contribution of forests reaches $46 \%$, agrocenoses $1,5 \%$, i.e. more than $90 \%$ of the products in almost equal amounts to create a forest and grassy biomes.

The high production of grass ecosystems is causing the reproduction of their biomass in one year or less. The latter means that in one year, growing and dying more biomass than is contained in the average per unit area. In agrocenoses to harvest at the moment which is estimated phytomass, some leaves, whole plants, roots is dying out and is not included in the phytomass.

So, the higher the participation rarely used in the economic activity of forest vegetation of the Republic, the higher phytomass and longer time of reproduction of the biota. The higher participation of grass ecosystems, the higher production and less time on their reproduction. The maximum change in the flow of crop residues into the soil occurs in agrocenoses.

\section{References}

1. Titlyanova A.A. Biological carbon cycle in the grass ecosystems. - Novosibirsk: Nauka. 1977. 219 p.

2. Agroclimatic reference Krasnoyarsk Krai and the Tuva ASSR. - Leningrad, Gidrometeoizdat, 1974. - 215 p.

3. Sambuu A.D. Anthropogenic vegetation dynamics of Tuva. Kyzyl. TIENR SB RAS. -40 p. 


\section{Materials of Conferences}

\section{CLASSIFICATION OF LOGISTICAL SYSTEMS AND OPTIMIZATION OF GOODS CIRCULATION PROCESSES}

${ }^{1}$ Balgabekov T.K., ${ }^{1}$ Malybaev S.K., ${ }^{2}$ Matkerimov T.Y., ${ }^{1}$ Hajbullin R.R., ${ }^{1}$ Rozhkov A.V., ${ }^{1}$ Frolova S.O., ${ }^{1}$ Erzhumanova A.K.

${ }^{1}$ Karaganda State Technical University, Karaganda,e-mail: frolova_sv@mail.ru. ${ }^{2}$ Kyrgyz State Technical University named after I. Razzakov, Bishkek

Logistics is the acknowledged critical reserve aimed at the decrease of expenses in the field of resource transportation.

In modern market economy three spheres of the movement of resources objectively exist and interact: sphere of commodity production, sphere of the address of goods and services, sphere of consumption of goods and services.

In fig. 1 it is shown classification of logistic systems.

Logistical system [1] is the adaptive feedback system that performs certain logistical functions and operations, consisting usually of several subsystems and having developed relationships with the external environment.

In the late eighties and at the beginning of the 90th major western companies sought to develop global logistic strategy [2]. The dominant idea of the rapid development of the logistics in that time was the maximum integration of the logistical functions of the company and its logistical partners into a so-called full logistical network: "procurementproduction-distribution-sales" to achieve the ultimate business goals with minor expenses.

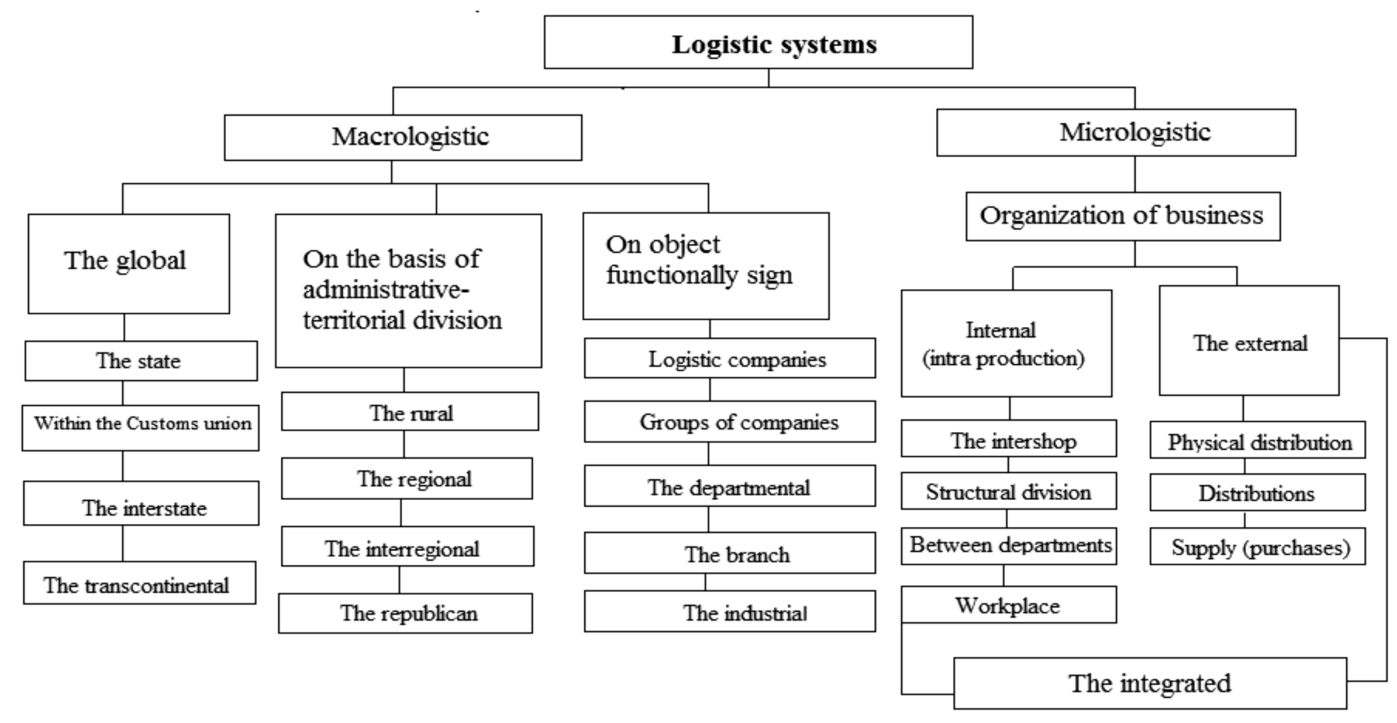

Fig. 1. Classification of logistic systems

As the commodity production develops, it becomes much more complicated, as the production involves a growing number of businesses, often located on the territories of regions around the world (so-called "global production"). Consumption of goods and services, in turn, becomes more and more various, focused on the accounting of individual requirements of buyers and customers.

In such circumstances, there is an urgent need for reselling enterprises, operating in the sphere of circulation of goods and services, i.e. between the producers and consumers. These enterprises, which represent the wholesale and retail trade companies, forwarding, transport, communication, warehousing and container management, financial, informa- tion, marketing, advertising, insurance, customs, security organizations, form the infrastructure of the commodity market.

A decisive role in the development and approval of an integrated logistics concept has been promoted by the possibility of permanent control of the product flows on real time basis in remote access modes through information communication systems $[3,4]$.

The term "infrastructure" came from Latin words - infra meaning "below" and structure - "structure". The infrastructure of the commodity market is defined as a set of non-manufacturing businesses and organizations that serve for the efficient operation of economic flow processes. 
The infrastructure of commodity market does not create new products, but increases the cost of production, which has already been delivered by the productive sector of the economy. This infrastructure added cost is associated with the implementation of services connected with management, marking, forwarding, loading, unloading, transportation, warehouse processing, storage, insurance, protection and sale of material assets, with the imposition of taxes, excises, and duties.

Efficient infrastructure implies the optimization of costs, added to the price of the products, which should ensure the competitiveness and, consequently, the demand for these products on the commodity market. Today the share of such added costs often exceeds $1 / 3$ of the final price of the realization of the products in our country. Based on this indicator the CIS countries, are unfortunately ahead of many countries in the world due to the substantial backlog in the levels of development of distributive trade, warehousing, transport systems, high tariffs for their services, poor organization and management of production flows.
Analysis and search of ways to improve the goods circulation is based on the crucial logistics assumption - comprehensive approach. It refers to the need to consider the entire goods circulation process as a combination and the integration of its stages and elements based on the congruence of interests of all parties of this process.

It is the comprehensive approach that enables logistics not to only optimize the processes of physical distribution. Research and experience confirm the fruitful opportunities of logistics to optimize many other flow processes associated with human activities. Such opportunities are, for example, addressed in the social sphere.

One of the important concepts in logistics is the logistical chain (fig. 2), that is, the total order of elements of logistical system (variety of enterprises and organizations carrying out the transactions to bring product from one system to another), organized by material (information or financial) flow aimed at the analysis or synthesis of a specific set of logistical procedures [3, 4].

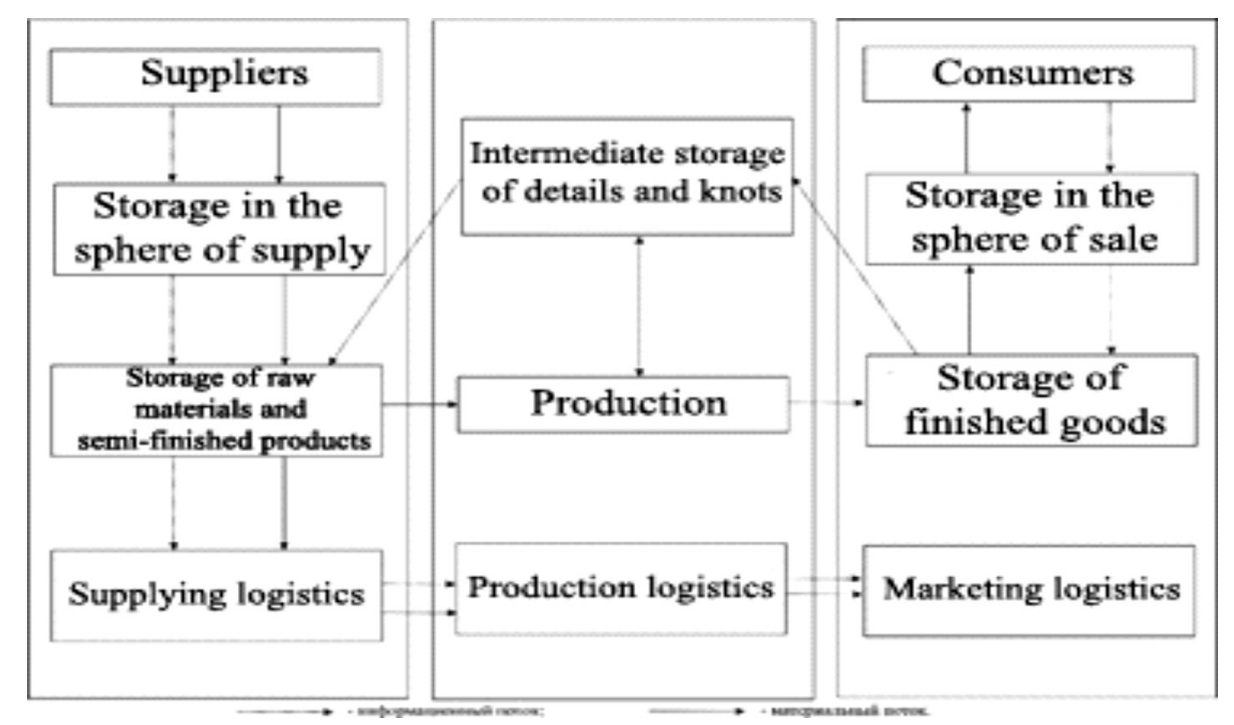

Fig. 2. Main links of a logistic chain

Process of production interacts with system of logistics in two directions.

Firstly, production has to regularly resupply finished goods in distribution system and which is especially important, to meet spontaneous requirements irrespective of, whether products are standard, modified or special. Second, production depends on system of material security regarding raw materials, other materials and component parts in certain quantity and of certain quality. Thus, the material elements of logistics include vehicles, warehouses, means of communication and management, and also the staff, that is the workers who are carrying out the consecutive operations.

\section{References}

1. Rodnikov A.N. Logistics. Glossary. 2-nd ed. revised and expanded. - M.: INFRA-M, $2000-352 \mathrm{p}$.

2. Semenenko A.I. Sergeev V.I. Logistics. Fundamentals of the theory: A Textbook for high schools. - St. Petersburg.: Union, $2001-544 \mathrm{p}$.

3. Albekov A.U., Kostoglodov D.D. Introduction to business logistics: Textbook. - Rostov-on-Don: Izd RGEA, 1996 - 197 p.

4. Nasipkaliev A.A., Adilova N.D., Balgabekov T.K. Transport logistics: Textbook. - Karaganda KSTU, 2007 - 111 p.

The work is submitted to the International Scientific Conference "Modern science technologies", Spain (Tenerife), November 21-28, 2014, came to the editorial office on 18.10.2014. 


\section{THE REAL SECTOR OF ECONOMY PECULIARITIES}

Danilina E.I., Gorelov D.V., Malikova Y.E. Moscow,e-mail: danilina05@mail.ru

The main issues of the real sector of the economy, its composition and structure have been considered, the foreign experience has been shown, and the recommendations have been provided to be further improved the production efficiency growth in the paper.

The modern economy is consisted in five main sectors:

- The non - financial corporations - the commercial organizations, having produced the goods and the non - financial services for the market;

- The financial corporations - the organizations, having provided the financial intermediation services and the issue of securities proceed;

- The power bodies authorities of the various levels and their subordinate Institutions;

- The households and the family business enterprises (e.g. the personal and private subsidiary holdings, the farms, and etc.);

- The non - commercial organization (NCOs), having produced the goods and provided the services on the non - market basis and having had the right to be used the profits only on the statutory and charitable purposes, but not for the dividends and bonuses payment, etc.

The state and municipal sectors of the economy are included not only the state management system, and the commercial and non - profit enterprises and Institutions complex, that are fully or partial owned by the state and local self - government, the resources of which are usually used on the basis of the special legal - normatively framework, as well as the material and financial resources, having owned to the state and municipalities. Thus, the private property forms, for all this, are the majority ownership, as well as the blocking stake, "golden" share, if it is given the right to be made the strategic management decisions. So, the state and local self - government are not only, as the political organization, the source of the power, but also, as the special sector of the economy, with its technical - materially and resource base, the control system, and economic ties.

On the role of the state and municipal sectors in the economy, it can be judged by its specific ratio and proportion in the volume of the sales production realization, e.g. GDP, the value of assets, investments, revenues and expenditures of the consolidated budget, and the number of the employee jobs. In various countries, this specific ratio and proportion is usually made up from 30 up to $60 \%$, so, it is, particularly, high in Russia, and other countries with their transition and dynamical economies (e.g. China, India, Brazil, Singapore, Vietnam, and the others).

In the XX-th century, the public expenditures specific ratio and proportion in the Gross Domes- tic Product (GDP) has been grown in 3,2 times in Japan, in 3,6 times - in France, in 4 times - in the USA, in 4,7 times - in Germany, in 10 times - in Sweden. In the United States it has already been reached $30-35 \%$. The GDP, in EU it is $5 \%$, and in Sweden $-65 \%$ [1]. According to R. Greenberg data [7], the state's share in Russia's GDP - 29\%, Austria, Germany, France $-47-48 \%$, and Norway up to $80 \%$. Russia, the area of which is exceeded $17 \mathrm{mln}$. sq. $\mathrm{km}$, from which $70 \%$ is located in the Northern regions, and its boundaries are drawn on the 4 th. $\mathrm{km}$. in the longitudinal, and on the 9 th. $\mathrm{km}$. in the latitudinal directions, is practically needed in the strong government and state power for its geopolitical functions and the livelihood and the sustenance of the population execution [10]. However, the number of the people, having employed in the public budget sector per thousand population is 1,4 time higher, than in the OECD countries, and in 2,5 times higher, than in the countries with the medium level of the development. $38 \%$ of the active population are employed in the public state sector.

In the industrial economy, the armaments production, infrastructure (e.g. mail, railways, etc.), and finance have, mainly, been concerned to this sector. In the context of the globalization and innovation economy formation, this sector is included (e.g. with the private capital participation):

- the military - industrial complex, first of all, the aero - space industry, aircraft - and shipbuilding, manufacture of the special equipment, electronic and information technology;

- the innovative - educational complex, including the state and government scientific and research centers, Universities, industrial parks, patent - information system;

- the infrastructural complex, first of all, main pipelines and power grids, meteorology, hydro-economic and environmental complex;

- the fuel and energy balance complex, the production and further distribution of electricity, gas, water, energy efficiency system;

- the socio - cultural complex - social funds, education, public health, budgetary establishments and Institutions, having provided the social services free tall or at special and reduced prices, museums, libraries, and etc;

- the financial complex - the central bank and its institutional units, the state - controlled banks, and other monetary - and - credit organizations and Institutions, the financial intermediaries, the stock exchanges, the financial supervision system;

- the municipal services economy, including the construction and maintenance of roads, civil engineering structures and constructions, communication lines, streets and public and social buildings, environmental objects, energy, water supply and sewerage system, public transport and other sectors and branches of municipal public utilities.

The state and municipal economies management are practically performed by the legislative 
(e.g. representative), executive, and judicial power bodies, subordinate them to the supervision, control, tax, customs and financial (e.g. budget and treasury) systems. In managing the state and municipal economies, the soft budget constraints are usually used, having allowed not to be bankrupted and not to be closed the socio - important organizations and Institutions, even at the temporary loss.

It should be noted the advantages and challenges, associated with the high proportion of the state public sector in the GDP. The experience of China, Norway, Brazil, Singapore and also other countries, where the investment and instrument and ship - building companies are belonged to the state, has been shown, that by competitiveness, they are completely equal, and quite often are superior to the private ones, thanks to its focus on the solution of the strategic and national objectives and challenges, of the national, state and public control over the price - formation, using the incomes, staff recruitment, and etc.

In Norway, the oil and gas revenues and incomes have purposefully been used for the further development of the non - extractive branches and industries, science, education, and pension fund replenishment. The experience of China is widely known, where the heavy industries enterprises have not yet been privatized, and, at the end, they have been transferred to the market economy. Brazil, on the basis of the public sector, has been become the world leader in the aerospace and shipbuilding, electronics, biotechnology and bioengineering, the development and direct use of the new technologies in oil and gas offshore and on the shelf. Singapore, where the economy is led by the National Investment Fund, is in the lead in the high - tech industries manufactures competitiveness and the business environment quality.

The pharmaceutical industry of the world is in the private hands, but its further consolidation is practically led to the monopoly and constant increase in drug prices. In 2012, Americans have spent on them, according to the WHO, \$ $263 \mathrm{mln}$., since 2007 the prices of many drugs have already been doubled, including against Diabetes - in 1,6-4 times, the new drugs in the country are cost patients, in average, more $\$ 10$ th. monthly. In 2007-2014-es, about 2 mln. doctors have been arrested in the USA, the owners of the local clinics and pharmacies, the firm - producers, which have been caused damaged to the budget of $\$ 6$ bln., having written out the bills for the unnecessary procedures and transactions, the receipts for the healthy people care, etc. The Public Health Ministry (PHM) has revoked licences 17 thousand known clinics and 118 non - existent hospitals [8].

In Russia, in 1990-es the wholesale industry privatization has been carried out. The enterprises and companies have been transferred at the low prices (e.g. by book value, without hyperinflation, intangible assets, etc.) are close to the government entities, that do not have any experience in the large business managing. For all this, the government orders for the military and other equipment have been drastically reduced. As a result, the new owners for a pittance have sold abroad the strategic stocks of the raw materials and materials, supplies and equipment, etc. and they repurposed the factories and plants, Scientific Research Institutes (SRI) and Design Bureaus (DB) in the shopping and entertainment malls and complexes, centers, warehouses, and low - tech productions.

The wholesale privatization, spontaneous conversion, and foreign economic relations liberalization have already been led to the collapse of the high - tech industries and branches, scientific and industrial complexes, leaving from the science and leaving to work abroad the most valuable human resources, the loss of a number of the promising technologies. The technical equipment of the science, a number of the enterprises and companies, having engaged in the innovation and ordering, payment and work prestige of the scientific and technical personnel.[3].

The special and particular damage has been caused the instrumentation, instrument making, radio electronics, machine - tool construction. According to the "Rospatent" data, the intellectual property has been made up more, than $60 \%$ of GDP USA, Western Germany and other developed countries, but it is less, than $1 \%$ of the Russia's GDP. The research intensity of the transport engineering and machine building of the leading and major foreign countries and powers (e.g. the ratio of $R$ \& D expenditures to the total volume of the sales) has been exceeded $10 \%$, while in Russia - it is less, than $1 \%$. The Russia's share in the world market of the high - tech production is made up $0,5 \%$.

In 90-es, the Russian microelectronics - the basis of the high - tech complex has almost been destroyed. The microcircuit chips size of $0,8 \mathrm{mCi}$, suitable for the household appliances, are produced in Russia. The production of the chips $0,18 \mathrm{mCi}$ for the social and payment cards, contactless monthly or season tickets, biometric passports (e.g. here, "Sitronics" will be taken $100 \%$ of the market area) has been organized at the "Sitronics" plant in Zelenograd (e.g. the Moscow Region) and etc. Then, the production of the chips has been arranged, that are usually required for the digital television receivers, antennas, the "GLONASS" navigational system, and etc.

The low proportion of state expenditures and government spending - is not the cause, but the consequence of the high level of the economic development. The most developed countries and advanced powers can do without any subsidies of the housing and communal services complex (HCSC), as the average salary in the USA - is more, than \$ 20, in Western Germany \$ 24 per hour. In Russia, it is several times lower, so the transition to $100 \%$ payment of the HCSC utility bills would be caused, 
finally, the social explosion. In China, the low level of the non - interest budget expenditures is related to the fact, that $70 \%$ of the population - are the villagers and rural people, having lived on the intensive agricultural farming on their plots, without getting any pensions, benefits and HCSC services. In a number of rather small countries, it is due to the lack of the need to be maintained the large army, the rocket and space forces, and etc.

It should be noted also, that Finland, Sweden, Norway and other countries are occupied the first places on the competitiveness of their national economy, where the share of the state expenditures and government spending in GDP is not lower, or even higher, than in Russia, at the expense of their spending on education, public health, and science.

The main content of the economy further modernization, as it has already been noted by several researches, is to be increased and to be further improved the quality of the state and government regulation of the economy, and not to be waived from it. The foreign economists have criticized the liberal - radically ideas of "Reaganomics", not taken into account the human capital, as the basis of the new economy, the change in the capital structure, the further transition to the online and network methods of the business organization.

In South Korea and China, the volume of the microelectronic components production in 300 500 times more, than in Russia, and in 4-5 times is exceeded the cars production, or the volume of the oil consumption. Over the past 20 years (or 240 months), the 2-3 generations of the process and technological equipment have been replaced. The microelectronic digital equipment and technology are made up to $85 \%$ of the newest equipment cost, in the middle apartment more, than 40 ones are equipped with, and in the car-more, than 30 microcontrollers. Russia has to import more, than $80 \%$ of the electronic equipment, including for the military purposes. A number of the countries are, severely, restricted the sale of the certain types of the microcircuit chips to Russia.

By 2013, according to the "Rosstat" and "The Development Center of the HSE SRM" data, the average annual number of the employees in the industry has been made up 13,2 mln. people, including $10,2 \mathrm{mln}$. - are in the manufacturing industry, about $2 \mathrm{mln}$. - are in the production and distribution of electricity, gas and water, more, than $1 \mathrm{mln}$. - are in the mining operations sector. Of 450 thousand of the enterprises, 405 thousand ones are related to the manufacturing industry, including 88 thousand - to the mechanical engineering, instrument making, production of the electrical electronic and optical equipment, transport vehicles. Here, Tatarstan, Kaluga and Ulyanovsk Regions (RF) have already been achieved the greatest successes. However, the overwhelming majority of the enterprises and businesses are quite uncompetitive in the world market.
The industry is accounted $25,3 \%$ of GDP, but the manufacturing industry - is only $13 \%$.

The Russian economy has been come to its transition point. The current liberal and economic strategy is aimed at the macroeconomic stability, inflation reduction, and the budget deficit. It is achieved by the withdrawal of the funds from the economy, the investments of the export revenues into the reserve and debt obligations of the other countries and powers, the corporate debt increasing, the funding reallocation of education and public health care to the local budgets. In the globally unstable and turbulent economy (e.g. "the new chaos"), this strategy, practically, has been reduced to almost zero growth in the economy, has been led to the sharp decline in the investments and the capitals flight, the business profitability reducing.

In 2012-2014-es, the sales profitability, according to "The Center for the Macroeconomic Analysis and Forecasting", has been declined from 9,7 down to $5-6 \%$, the population debts on their loans in 2007-2013-es have been increased from 14 up to $21 \%$ of the disposable household income, the multiplier effect of the state and government megaprojects has been declined, the $1 / 4$ investments is not being paid off, and their overall profitability (e.g. $7 \%$ ) is lower, than the price of the credit (e.g. 9-10\%) and the incomes from placing the funds in the bank deposits (e.g. 10\%). The main income is being generated not by the production, but by the natural, exclusive, administrative - politically rent, which is produced by the natural resource companies, and monopolistic intermediaries. [5].

Russia is needed the new growth model [6], having orientated not only on the balanced budget and decline in inflation, but, above all, the economic growth acceleration [7], by the strategic investments increasing in the modernization of the economy [9]. According to S. Glazyev's and other economists' opinions [2], [4], in the framework of the previous monetarist - liberally macroeconomic paradigm, the development of the real anti - crisis management strategy is completely excluded. The free movement of the capital market is not solved the challenge, especially, since the Russian markets do not have their sufficient capacity, they are speculative, and they are depended on the non - residents financing, and they are not available for the majority of the domestic manufacturing enterprises. The domestic market, which is under the pressure of the foreign competition, is not, practically, capable of without purposeful government policy, to be solved the challenges of the economy modernization and the further rise of its high - tech branches and industries. The commercial banks are not able themselves to be increased its capital up to the level, that is met the needs of the real sector.

The main reason of the economic growth stagnation - is the growth rates slowdown in the labor productivity (e.g. from $7 \%$ in 2006-2007es up to $2-3 \%$ in 2012-2013-es) and the loss 
of compensating the low efficiency of the resources cheapness production. The tariffs of the natural monopolies have been grown in the recent times by $15-18 \%$ annually. According to the experts data (e.g. "Expert", 2013, № 40), the transport costs in the extended Russia for $55 \%$ are higher, than in the USA, the gas is more expensive, in a number of the places the salary has been exceeded its level of Hungary, Lithuania, Latvia, but the development of an employee in the 100 great companies (e.g. 18\% per year) in 3,4 times less, than in Japan, in 3 times less, than in the USA, in 1,7 time less, than in India and Brazil, and it is almost the same, as in Kazakhstan. Of 10 leaders in the labor productivity in the EES, 7 from 50-16 are working in Kazakhstan (e.g. the subsidiaries firms and companies of the oil and gas MNC), two in Belarus (e.g. Nozirsky Oil Refinery and "NAFTAN").

In the various regions of Russia, the development of an employee is, practically, made up $63 \%$ of the world level, in the major companies of the energy, oil and gas, telecommunication, scientific and industrial sectors $-45-49 \%$; black and non ferrous metallurgy - 35-38\%. From $87 \mathrm{mln}$. employable Russians, about $3 \mathrm{mln}$. are engaged in the security, defense and law enforcement agencies, military and policing branches; about $4 \mathrm{mln}$. - are in the ministries, pension and insurance funds, supervision and control services; about $2 \mathrm{mln}$. - are in the security and preservation organizations. According to the President of "Rosagromash" K. Babkin data, for the obsolete building and other regulations, the Russian Tractor Factory should be taken several times larger area more, than the Canadian, and the administrative staff is more, than 4,5 times (e.g. 65 and 14), including the security officers - in 37,5 times. Only by these two occupations, the additional costs - are about $\$ 3 \mathrm{mln}$. annually.

The production facilities have already been outdated for $80 \%$, the qualified staff - is in the acute shortage, the credit is being given for a short (e.g. up to 3 years or 48 months) term. The monetary policy orientation is not on the production, and on the import, the inflation is being increased, especially, if the flat rate of the taxes is the same for the citizen, whose income has been created by the labor, and the oligarch, having lived abroad and having come, only to be collected the rent, under the free movement of the capitals.

Russia has its ability to be, dramatically, improved the production efficiency, on the basis of the new creation and elimination of the obsolete working jobs, especially, in the area of the municipal, urban and agricultural infrastructures, roads, power industry, machine building, APC, share increasing in the investments in GDP from 20 up to $27-28 \%$ annually. This will be compensated for the gap in the amount of the savings and productive investments, having constituted, according to the experts' assessment, 7\% of the GDP. For this purpose, you are needed the real public state and government private partnership, having attracted the private rather, than the public and foreign investments, the new tools of the concessional long - termed loans, the further development of the sub-federal and corporate bonds, the creation of the lucrative market housing and communal services, on the basis of the new technologies and real competition.

\section{References}

1. Volostnov N.S., The State - Owned Enterprises under Market Economy Conditions. - M., 2004. -№ 1. - P. 320.

2. Glazyev S., Fetisov G. The New Deal: Breakthrough Strategy // "Econ. Strategy", 2014. - № 2.

3. Dashitzev B. The collapse of Russia in 1990-es, Causes and Consequences, in the Assessment of Its Contemporaries // "Economic Strategy", 2013. - № 5.

4. Kuzyk B. On the Formation of the Strategic Management System by Modernization and Development of the Russian Economy // "Econ. Strategy", 2014. - № 2.

5. Levin M., Satarov G. The Rent - Seeking Russia //"Issues of Economy". - 2014. - № 1.

6. Mau V. In Anticipation of the New Growth Model // "Issues of Economy". - 2014. - № 2.

7. (NG. ru, 05.2012).

8. (NG. ru, 14.05.2014).

9. Popov S. The Competitiveness strategy, on the Basis of the Root Investments // "Econ. Strategies". - 2010. -№ 11.

10. Yakobson L.P. The Public Sector of the Economy: Economic Theory and Policy". - M.: "HSE SM", 2000. - № 2.

The work is submitted to the International Scientific Conference "Production management. Accounting, Analysis, Finance", London, October 18-25, 2014 came to the editorial office on 04.10.2014.

\section{SPECIAL FEATURES OF ORGANIZATION-STAFF WORK WITIHN STATE BODIES IN MODERN CONDITIONS: DOMESTIC AND FOREIGH EXPERIENCE}

Danilina E.I., Golosova V.A., Shmackov E.V., Piralieva M.I. Moscow,e-mail:danilina05@mail.ru

The article studies basic trends of organizationstaff work in state bodies in Russia.

Transition of Russian economy to the world space, related to the sixth technological tradition leads to global changes, including correction of problems, faced by bodies of state government. Attitude towards work and employees suffers a change.

Qualification, professionalism, knowledge, and ability to create become basic characteristics of an employee. A worker not only supplies his professional qualification to employer for a fixed period of time. Person becomes a subject of professional relations, as an employee takes responsibility for his personal development. Managing such personnel defines inefficiency of the existing model of Taylor that considered industrial technologies, designed for mass production, developed distribution 
of labour, using a person's knowledge and skills in a narrow specific area (profession and specialty). Evaluation of work result was based upon one's skill to carry out a specific operation.

Nowadays a greater part of labour, including its intellectual kind, is being automatized. Informatization of the society creates completely new spatial-temporal relations. Content of work is more and more transferred to interaction not between a person and mechanism, but between people via machines. At the same time we can observe:

- Growth in productivity of monotonous labour that consists of repeated operations, decreases its part in total consumption of work. Part of professions that are not related to direct production, grows (research, development, marketing).

- New professions are created instead of the old ones, and they demand completely new competences from employees.

Robots replace accountants, cashiers, security guards, dispatchers, and many other professions in the area of management. A specific regulation of working time is being introduced. A number of employees who work outside an office at the basis of labour contract, increases [6] as well as a number of qualified workers from other countries, not only CIS, but, possibly, from Vietnam, India, etc. New professional standards define training specialist of 400 wide professions (Labour code counts about 7000 of them).

As it is registered by domestic literature, modern state apparatus requires increase in qualification and in decrease in quantity of personnel. According to the data of Rosstat, 793 thousand people were employed by state bodies in 2014 (decrease by $12-15 \%$ in comparison to 2010). At the same time, total number of state and municipal officials, including members of electoral commissions grew from 1,162 to 1,548 thousand people since 2000 to 2013, at municipal level it grew 2,5 times.

Manning of federal official bodies equaled $82 \%$ in 2013 , regional $-90 \%$, municipal $-96 \%$, and monthly wage equaled 98000 rubles (increase by $36 \%$ during a year), 36400 rubles, and 33600 rubles correspondingly. In a number of small towns officials form up to $80 \%$ of the total number of the employed. According to institute of social policy of scientific-research university High School of Economy [4], number of officials per 1 thousand of people equal 70-72 in USA and France, 40 in Latvia, 33 in Italy, 25 in Norway, 18,5 in South Korea, 12 in Russia. The greatest part of officials in total number of the employed is registered in Latvia - 10\%. However, part of official government costs in state budged is much greater in Russia than in countries of OECD. The greatest part of state personnel is not skillful at modern informational technologies.

Decrease in quantity of state apparatus goes along three basic directions:

- Liquidation of unnecessary, unnatural for a country, and inefficient functions of government (according to experts, their part equals 20-30\%).
- Liquidation, unification, and removal of duplication in operations of observation-control bodies.

- Transition towards providing state services digitally, creation of single network that will link all official structures, sharp decrease in paperwork and report.

International institute of management evaluates efficiency of managing economy of different countries according to 333 criterions. The leading positions are occupied by USA, Sweden, FRG, Canada, UAE, Denmark, and Norway. In 2014 Russian occupied the $38^{\text {th }}$ place - behind China $\left(23^{\text {rd }}\right.$ place) but ahead of Brazil and India. Specific part of citizens in age of 18-64 who plan to start their own business in nearest years during 20022012 increased from 27,5 to $43 \%$ in China, from 5 to $7,7 \%$ in Finland, in equals $37 \%$ in Brazil, and it decreased from 2,5 to 2,2\% in Russia. Part of population in age under 64 that already has a business increased from 12 to $24 \%$ in China, from 4,6 to $6 \%$ in Finland, it equals 15,5 in Brazil, and only $2,4 \%$ in Russia. Monopolies, related to local authorities, suppress competition.

According to researches by Ernst \& Young "barometers of business activity of G-20", according to business support coordination, Russia is placed at the same level with Mexico, Brazil, and Indonesia, but behind China, where about $75 \%$ of new workplaces were created due to this support. According to the level of business culture, professional training of entrepreneurs, and business environment, Nizhegorodskiy region and a number of other regions have been outlined.

During evaluation of staff potential one should consider not only coefficient of their intellectual development and analytic abilities, but also emotional intelligence - ability to understand feeling and intelligence of others, interact with them, develop their creative thinking and initiative, create efficient teams (team management). It is necessary to train staff to work in collaboration without introducing numerous positions of deputies and assistants of managers who are unable to organize systematic workflow. Additional professional training o state officials should be directed towards projective work not only in western (Institute of state management of Georgetown university of USA, Higher normal school of France), but also eastern centers.

Institute of state service in Singapore, Beijing and Pudun schools of state government in China, and others are directed towards collaboration, but not only individual leadership. It is much closer to Russian mentality.

The greatest attention is paid to modern neuroeconomy that implies revolution in behavioral economy. It studies mechanisms of making decisions in terms of uncertainty, when possibility of achieving a goal is difficult to evaluate, and rationality of a certain line of behavior is defined by collective values and preferences. 
A special significance is devoted to the system of state and municipal orders that carry out the following functions:

- participation in ranging values of management objectives and means of achieving them;

- distribution of financial-budget resources during separating authorities of federation, regions, and municipal bodies (MB);

- provision of efficient workflow of state and municipal consumers of goods and services;

- standardizing of contractors' activity, selection of the best investment-innovative projects and business-plans;

- rationalization of taxing, selection of legal form of organization and choosing head executives of contractors;

- transferring actives to property or transferring them to contractors of competitive goods in accordance with conditions of a contract.

Bodies of government must evaluate efficiency of investments considering all types of risk and paths of project financing development.

Indexes of internal profitability of a project are considered first, however, it is not enough. Bodies of state government should also consider external effect, related to profits, that a customer receives: creation of new workplaces, decrease in unemployment and crime rate, improvement in social and business capital, ecology, and health of population.

Activation of capital, including non-material actives, should become a source of investments [3, 5]. During 2000-2012 Russian budget grew almost 4 times in real expression, and capitalization of stock market grew 5 times (from 0,2 to 1 billion rubles). However, according to Morgan Stanley recapitalization of Russian companies decreased to 60 of value of their actives [2]. It is necessary to decrease period of selecting investment projects and simplify the procedure of providing state guarantee.

A state body can't serve as a partner to private firm as they are in authoritative, not civil-legal relations. According to the research by McKinsey, attracting private capital to state infrastructural projects cuts down costs by $20 \%$, risk of budget increase - by $70 \%$, and risk of construction period increase - by $66 \%$. Public sector of economy (non-commercial organizations) manages social infrastructure. Associations of users are much more efficient than state or private firms when it comes to managing forests, water, and other resources.

New area of activity for state and municipal personnel becomes development and efficient usage of new sectors of infrastructure. Infrastructure is a system of economic and non-commercial organizations and that provide services, required for improvement in their activity and efficient production, to economic subjects, located at a given territory.

Five basic blocks are outlined in infrastructure. Commercial infrastructure that includes banks and other financial institutes, markets (stock, goods, currency, etc.), insurance companies, marketplac- es (wholesale markets, distribution and storage of goods), expert-consulting, legal services, audit, advertising and marketing services, and is necessary for efficient production and realization of goods and services in terms of competition.

Production-ecological infrastructure includes railway, automobile, maritime, aviation transport, highways, connection, power system (electricity, heat, gas), water supply and sewage, nature-preserving system and existed in centrally-planned economy (in opposite to commercial).

Innovative infrastructure includes fundamental science, innovative networks, metrological, optical-experimental, and leasing centers of general purpose, patent-licensing service, engineering (introductive) firms, system of training and additional training of scientific-technical personnel.

Social infrastructure consists of education, healthcare, pension system, and other social services, it obtains a special significance in economy of knowledge.

During the nearest coming years state apparatus should solve a completely new problem - carry out the greatest organization-technical re-equipment of industry and the whole economy in half-century. In 2015 it is planned to re-evaluate all industrial funds, estimate enterprises of industry, transport, and communication in order to reveal outdated main funds (they form up to $80 \%$ of their value) and liquidate technologically-outdated enterprises, especially outdated in ecological area, via increasing taxes for outdated funds, toughening standards of their usage, buying them off by the state, etc. For certain monotowns it implies a necessity to retrain employees, develop small and average business rapidly, provide new workplaces in neighbor cities (which defines the need for highways) and other regions.

New funds should replace the outdated ones, system of reconstructing potentially-competitive existing enterprises is required [1]. These measures will demand localization of production of foreign equipment, development of non-raw materials export, decrease in prices for long-term (10 years and over) investment credits down to $1 \%$ plus inflation, state-private investment partnership at the foundation of implementing concessions for all types of infrastructure.

The following basic directions of economic transformation through impact of state and municipal authority are:

1. Development of small business, first of all, in high-tech sectors, creating of highly-productive workplaces. According to the data of Rosstat and Chamber of commerce and industry, during 2010-2013 over 1,5 million workplaces with salary over an average regional level were created, about 350000 - in Moscow, 240000 - in St. Petersburg, about 200000 - in Tatarstan, 160000 - in Bashkortostan, about 100000-126000 - in Krasnodar, Moscow, Sverdlov, Rostov region, about 70000-80000 in Nizhegorodskiy and Kemerovskiy region. 
2. Qualitative change in system of training, retraining staff, improving its qualification. The greater part of authority bodies personnel is formed of people of pensionary and pre-pensionaty age who are unfamiliar with modern informatics. In early 2000-s labour value in Russia was significantly lower than it was abroad. Since these days average salary increased more than 5 times (in dollar expression) and now it exceed the level of it in Bulgaria, Romania, and a number of EU countries. At the same time, incomes of executive managers exceed salary of regular employee more than 150 times (in Northern Europe and FRG - 5-10 times). Only in USA by 2015 average annual income of chief executives of corporation was more than USD 10 million -250 times average salary.

The basic quality of modern manager is his ability to collect, analyse, and use new information, his speed of reacting to changes in the world. Narrow qualification loses its significance and is being replaced by competence - possession of a wide range that allows one to transfer knowledge from one area of professional activity to another. If a company changes its profile, its personnel should also possess the necessary competence, managing such team also requires certain competence that will base not only upon professional skills, but also individual knowledge and abilities. The existing labour market demands a person that has rare and sometimes even unique qualities within the required professional range. As practice shows that order in management is the main criterion of attracting new employees.

\section{References}

1. Blyachman L.S. Restructuring of firms as a key link in transiting towards social innovative economy. // Problems of modern economy. - 2014. - № 3.

2. Vedomosti, 27/04/2014.

3. Golyand I.L., Zakhariin K.N., Mukhina K.A., Devinova V.V. Amortization as a component of investing into activity of enterprises // Problems of modern economy. - 2013. - № 3. - P. 211-216.

4. KP.ru. 19/10/2011.

5. Livshits V., Shvetsov A. What mistakes should be avoided while evaluating investment projects with state participation // Problems of economy. - 2011. - № 9.

6. Muradova A., Freelance A. When one is his own boss Moscow, Alpina Business Books, 92 p.

The work is submitted to the International Scientific Conference "Economics and management", THAILAND (Bangkok, Pattaya), December ,20-30, 2014, came to the editorial office on 31.10.2014.

\section{PERSONNEL COMPONENT OF INNOVATIVE DEVELOPMENT OF RUSSIAN ECONOMICS}

\section{Guremina N.V., Mansurov U.N., Smirnov V.P. \\ Far-Eastern Federal University, Vladivostok, e-mail:innov-man@yandex.ru}

The human component is crucial for the creation of a national innovation system. This issue has been given a lot attention to for the last years. The centers of technology transfer, industrial parks, venture investments funds and other elements of the innovation infrastructure have been established in all the regions of the country. The government provides small innovative business with financial support.

However, it's hardly to say that the economy of the country receives great amount of the innovative developments, new technologies, etc. The current situation is caused by many reasons, but ones of the main important of them belong to the personnel sphere.

First of all, we should mention the lack of innovative culture of the personnel at all the levels from common employees to management. Speaking about the innovative culture we mean ability of personnel to find or create promising development, desire to complete it to the innovation level and understanding of the impetus, given by the use of someone's innovations and by development of their own. The presence of the innovative culture will allow solving the following tasks:

- search for scientific development having potential for commercialization;

- identification of the innovative prospect and result obtained;

- organization of interaction of developers and innovative managers; vations.

- acceleration of practical application of inno-

The second reason - lack of the innovative managers and theoretical base of their educations. Now it is a serious problem to trained of innovative managers in Russia. With such human resource support of the national innovative system the efficient use of other types of resources, allocated foe the innovative economy establishment, is impossible. The level of their education leaves much to be desired too [1].

The third reason - lack of demand for the innovative managers. Analysis of job offers at most popular websites, dealing with employment issues, showed, that there only a few vacancies, connected with the work in the innovation sphere, out of hundred thousands of job offers.

Thus, nowadays and in the nearest future weakness of the human resource component is the main barrier to the national innovative system development.

Let's consider the development possibilities of human resource component of the national innovative system:

1. Formation of the "innovative culture". It is important in short terms (3-5 years) to teach the employees of various branches of the economy the innovations basics. The main basic course should contain:

- search, promotion and application of innovations including interaction of developer, heads at various levels, innovative managers etc. This part 
of the course is directed to generation of interest to innovations based on personal material interest;

- how to find the innovations. This part of the course determines the characteristic features of the innovations, how nor to miss the promosing result;

- whom to contact if one finds the innovations. This part tells about the innovative infrastructure of Russia.

This course needs a practical part in a form of business game.

2. Innovative managers training. This task lies in the preparation of several tens of thousands of the innovative managers during 3-5 years, which will have practical experience of work with innovations by the graduation from university. Provision of practical directionality in the innovation managers training. To solve this task it is necessary to do the following:

- innovation managers training at the senior courses has to be mainly done by the lectures having practical experience in the innovation sphere;

- education has to include 5-6 month practical training in the innovative company. Within this practice student completely prepares the innovative the innovative project and presents it to the potential investor;

- universities provided reinforcement of knowledge and practical skills;
- innovative companies got an opportunity to involve the students while preparing the innovative projects, and through that increased the volumes of their work;

- the students got the practical skills;

- increase of student's number, practicing in the innovative firms;

- involvement of new universities and innovation firms;

- promotion of the opportunity for distant practice, which will allow attracting students from other cities.

Thus, the task of personnel component formation is necessary to build the innovative system of Russian economics. This task has several components, each of which can be realized if there is an understanding and support from the government and participation of innovative firms.

\section{References}

1. Guremina N.V., Zhivotov V.A. Problems of Innovation Development of the Russian Far-East// European Journal of Natural History. - 2013. - № 4. - P. 31.

The work is submitted to the International Scientific Conference "Science and education in modern Russia”, Moscow, November 13-15, 2014, came to the editorial office on 03.10.2014. 


\section{Short Reports}

\section{INFLUENCE OF EXPENSES UPON MAKING A DECISION ON UNDERTAKING INFORMAL ACTIVITY}

Vidritskaya N.I.

Karaganda economic university of Kazpotrebnadzor Karaganda, e-mail: vidritskaya@yandex.ru

One of the reasons of informal economy is inefficient economic system, the totality of limiting frames, according to D. Nort, "rules of the game" that organize relations between people, and also methods of supporting these rules [1].

The role of institutes that consist of formal written rules and unwritten codes of behavior is in decreasing uncertainty via establishing a stable structure of relations between people. In an economy that operates efficiently, they don't exclude, but rather complement each other. At the same time institutes might limit and stimulate activity of business agents. Evaluation of efficiency of institutes should first of all consider reliability of state obligations, and secondly - level of expenses for using the rules. Thus, E. De Soto claims high price of obeying law to be the reason of prevalence of informal rules, he outlines two concepts within it: "price of access" to area of operation and "price of continuing" it [2].

"Price of access" includes expenses for passing administrative barriers that include costs for business or legal person registration, receiving patents, licenses, legal address, product certification, etc. However, as known, registration does not mean formalization of activity, as mechanisms of covert economy come in play: decrease in amount of total annual income in order decrease the sum of paid taxes, concealment of a part of revenue or distortion of listed number of staff, aimed to gain access to certain taxing regime, for example. At this point a businessman has to choose: pay the "price of continuing" his activity within the frames of law or bear expenses of "illegality" that are related to regulating activity through informal rules.

Expenses of continuing activity in accordance with the law include:

1. Costs, defined by high rates of budget payments: taxes, dues, customs tariffs, etc. Apart from tax duties that serve as a significant obstacle on the way of profitable operation, we have to state existence of numerous half-legal collections, so-called "compulsory but made to appear as voluntary" assignments for different municipal needs.

2. Costs of operating within formal economy that come along with budget payments: price of accounting, legal consultations, audit, paying for specialist in logistics, costs for tracking the changing formal rules, and correction of activity due to the introduced changes.

3. Costs, related to an excessive attention of controlling authorities towards enterprises that operate within "formal area". This phenomenon is defined by the fact that representatives of any controlling body are "bound to succeed" when they inspect a registered enterprise, since existing our legislation does not allow businessmen ability to protect themselves from mistakes. In fact, instability of formal business rules represents a greater risk than being caught in informal operation.

4. One among positive moments of operating legally is protection of violated laws in court, however, in practice businessmen often face illegal acting by judges, continuance and inefficiency of litigations.

5. Time and money costs, related to direct transactions, in other words, transactional costs (collecting information on a contractor's credibility, delays, related to bank payments, etc.)

6. Costs of liquidating a business, defined by the complicated and expensive procedure.

According to the provided information, let us introduce price of legality, defined by formula (1):

$$
P_{\text {leg }}=\left[C_{\text {reg }}+\frac{N_{\text {insp }}\left(S_{b r}+C_{\text {idle }}\right)}{L_{c}}+N_{\text {break }}\left(C_{\text {just }}-S_{\text {comp }}\right)\right]+S_{\text {tax }} \text {, }
$$

while $P_{\text {leg }}$ is price of legality, paid by a businessman who accepts rules, set by the state;

$C_{r e g}$ is costs for registering activity;

$N_{\text {insp }}^{\text {reg }}$ is number of inspections by controlling bodies (tax police, fire department, sanitary-epidemiological service, police, etc.);

$S_{b r}$ is totality of bribes that a businessman has to pay due to conflicts in requirements of controlling bodies and complexity of tax legislation;

$C_{i d l e}$ is costs of idleness, beared by a businessman due to inspections;

$L_{c}$ is corruption level in a given country (corruption index);

$N_{\text {break }}$ is number of violated contracts;
$C_{j u s t}$ is costs of protecting violated rights in court; $S_{\text {comp }}^{\text {just }}$ is sum of received compensations; $S_{t a x}$ is tax burden, in other words, total sum of taxes, paid by a businessman.

Let us outline that corruption level, of course, increases the scale of informal economy, but we think that this index is:

- inversely proportional to sum of bribes and number of inspections due to a high level of competition at so-called market of informal services that allows one to cut costs within certain limits;

- directly proportional to expenses for court, as it becomes almost impossible to prove one's rightness via legal methods without additional 
guaranteeing payments in terms of high corruption rate of legal instances;

- inversely proportional to costs for registration, as corruption defined bureaucratic delays, aimed to extort money.

Thus we can see that often "price of access" to legal area of activity and "price of continuing" it is excessive for business. However, during the process of functioning within informal environment businessmen also bear certain expenses - costs of illegality. Researchers [3, 4] outline the following types of them:

1. Serving informal schemes. It includes price for consulting on escaping taxes and other budget payments, allowance of additional staff, involved in accounting, logistics, costs of maintaining double financial report, costs of cashing money, etc.

2. Increased risks of maintaining informal operation: businessmen who operate informally, are constantly exposed to risk of being punished for lack of registration, license, unpaid taxes, etc. It is considered that representatives of informal economy spend 10 to $15 \%$ of their gross income for bribes and commissions, and law-abiding merchants spend no more than $1 \%$ for these purposes.
On the whole, however, businessmen evaluate risk of implementing strict sanctions lower than risk of target inspection by legal bodies, as there is always a possibility to "solve a problem" through established connections and relatively-low bribes. Routine nature of corruption relations allows one to decrease level of risk and uncertainty.

3. Costs, defined by periodically-missed profit due to maintaining informal operation and inefficient distribution of resources because of limiting circle of contractors, advertising abilities, decrease in business capitalization, etc.

4. Costs of obeying informal institutes: provision of business safety, including payments to controlling bodies and law enforcements as bribes for cancelling inspections and implementing sanctions, accelerated solution of problems, and also payments to informal (mafia-controlled) structures for solving problems, related to contract violations.

5. Costs of "crossing" legal sector of economy: taxes for goods and services, acquired in formal economy, and also inflation tax.

Formula (2) presents mathematical interpretation of the provided information

$$
P_{\text {illeg }}=\left[\frac{N_{n p}\left(S_{\text {brilleg }}+S_{p e n}\right)}{L_{c}}+N_{\text {breakilleg }}\left(C_{\text {justilleg }}-S_{c}\right)\right]+B
$$

while $P_{\text {illeg }}$ is price of illegality, paid by a businessman for refusing to obey rules, set by the state; $S_{\text {brilleg }}$ is sum of bribes that a businessman has to pay for the "permission" to continue operation within the area of "informality";

$S_{\text {pen }}$ is penalties;

$N_{\text {breakilleg }}$ is number of violated contracts in informal economy;

$C_{\text {justilleg }}$ is costs for protection of violated rights in informal (criminal) instances;

$B$ is unreceived profit.

Comparing formulas (1) and (2) we should outline that, sums of bribes, paid in informal sector of economy are several times larger than bribes, paid in formal conditions, the same notice is fair for the number of violated contracts and expenses for protection of violated rights. As a rule, price of legality is higher than price of illegality, since sum of registration and tax load is greater than difference between expenses in formal and informal economy. Let us underline that sum of the received compensations in informal economy might even exceed that in formal economy, as though "criminal" justice is much more expensive, it is more efficient since it implements strict punitive measures. Price of legality can be lower only in case there are significant unreceived profits, related to operating within informal economy.

Thus, according to this multi-factorial correlation, we can try to define probability of transiting to informal economy from formal version of it for businessmen. On the one hand lays one ability to decrease his expenses of maintaining business significantly, but, on the other hand, there are high risks of doing business informally. Which scale is heavier depends on how a state will establish real functioning of civilized institutes, acceptable level of taxes, and decrease in bureaucratic pressure.

\section{References}

1. Douglass C. North. Institutions, Institutional Change and Economic Performance (Political Economy of Institutions and Decisions) Cambridge University Press, 1990. - 159 p.

2. Hernando de Soto. The Other Path: The Invisible Revolution In The Third World Basic Books, 2002. - 352 p.

3. M.P. Stepanova Shadow economic activity in modern world // Labour abroad. - 2002. - № 2. - P. 36-56.

4. Barsukova S., Radaev V.V. Informal Economy in Russia: A Brief Overview // Economic sociology - The European electronic newsletter. - 2012. - Vol. 13, № 2. - P. 4-12. 


\section{Materials of Conferences}

\section{DIFFERENTIATED APPROACH ENDOTHELIOPATHY IN THE DEVELOPMENT OF IN WOMEN METABOLIC SYNDROME}

\author{
Mukhamedova N.H. \\ Uzbekistan Tashkent Medical Academy, \\ e-mail:nurhon6969@mail.ru
}

MS is one of the most controversial and topical problems of modern medicine. Its distribution amongst the planet's population is characterized as "non-infectious "epidemic.Nowadays a great attention is paid to the metabolic syndrome(MS), which is an index of hormonal and metabolic disturbances, that are united by common pathophysiological coreinsulin resistance. MS is one of the most controversial and topical problems of modern medicine. Its distribution amongst the planet's population is characterized as "non-infectious "epidemic. In common population MS is distributed from 14 to $24 \%$. In persons above $50 \mathrm{MS}$ is diagnosed in $50-60 \%$ of cases

Nowadays a great attention is paid to the metabolic syndrome(MS), which is an index of hormonal and metabolic disturbances, that are united by common pathophysiological core-insulin resistance. MS is one of the most controversial and topical problems of modern medicine. Its distribution amongst the planet's population is characterized as "non-infectious "epidemic. In common population MS is distributed from 14 to $24 \%$. In persons above $50 \mathrm{MS}$ is diagnosed in $50-60 \%$ of cases Initial symptoms of MS are already revealed in youth, that have hereditary predisposition towards diabetes, obesity and arterial hypertension. However the establishment of the MS diagnosis usually occurs several years after the debut of the disease. The latest works, which are dedicated to the MS investigation clearly indicate that cardiovascular system is the main target of the MS's components. MS plays a significant role in the process of atherogenesis, which leads to the development of cardiovascular complications and high mortality. In spite of the numerous research works, which concern the core mechanisms of the formation of MS's components, still there are no evident data about the character of the endothelial dysfunctions in the MS when the range of carbohydrate metabolism breach is taken into account.

The purpose of the study: To study the role of the endotheliocytes in the development of the MS.

Materials and methods of research. The study included 69 women aged 19 to 35 years at the age of 18-65. All of them had metabolic syndrome. Also 20 healthy volunteers participated in the research as the control group. The research work was conducted in the $3^{\text {rd }}$ clinic of Tashkent Medical Academy. Metabolic syndrome was diagnosed according to the currently functioning criteria which are elaborated by the experts of National Educational Cholesterol Committee (NGEP ATP III,2001).

The patients with the $2^{\text {nd }}$ type of diabetes uncontrollable arterial hypertension of II-III degree, the acute breach of cerebral circulation myocardial infarction, severe mental and somatic diseases, pregnancy and acute infectious diseases did not participate in the research work.

All the patients with the metabolic syndrome and the patients of control group had undergone standard oral glucose-tolerant test with the determination of glycaemia and the level of the immune reactive insulin on an empty stomach and after 120 min of glucose loading.

Glucose concentration in blood was calculated according to the glucoseoxydase technique with the help of the chemical agents of the firm "HUMAN". In order to estimate the insulin resistance the index HOMA-IR was applied. It was calculated according to the formula: HOMA-IR = (insulin on the empty stomach $(\mathrm{mk}$ Unit $/ \mathrm{ml})+$ serum glucose on the empty stomach(m Mole):22,5.

The internal nitrogen oxide (NO) production, endotheline-1 and Villebrand factors content were calculated with the commercially adapted set of the firms "technoelone","Biomedica" and "RSD", represented by the company "BioCim Mac"(Russia)on the immune-enzyme analysator of the firm"HUMAN". The quantity of the desquamated endotheliocytes were explored via the method of Hldovec J.(1978).

The statistical analysis of the acquired results was conducted with the application of the set of applied programs "Statistica". The statistically significant differences were by $(\mathrm{P}<0,05)$.

Results of research and their discussion. The comparative characteristics of the main and control groups' anthropometric figures are demonstrated in the table 1 . The groups were compared according to the sex and age. As it is clearly seen from the results of the research the waist and hips circumferences in these groups differed considerably.

The analysis of glucose metabolism and the dynamics of immune reactivity toward insulin revealed the significant changes in the studied figures. The obtained results clearly demonstrate a considerable increase of the glycaemia on the empty stomach,and also 2 hours after oral glucose tolerant test in patients with metabolic syndrome in comparison with the control group. However, they did not reach the criteria of the diabetes diagnostics. In comparison with the control group, the level of basal insulin rose 2,9 times in patients with the metabolic syndrome group. The indexes of HOMA-IR in patients with metabolic syndrome exceed 4 times the same figures of control group.

The binding link between the syndrome of insulin resistance and metabolic syndrome is the endothelial dysfunction. The endothelial dysfunction can be determined as the inadequate increase or decrease of the desquamated endotheliocytes'contents in the blood. These data confirm the presence of the vascular endothelium's considerable damage in the metabolic syndrome.

According to the formation of different factors in the endothelium(which is mainly connected 
with its structure), and also the NO(nitrogen oxide) secretion, which is constantly produced in the endothelium and is discharged from the cells in basolateral direction or into the bloodstream. A considerable decrease of the NO level was regis- tered in the examined. This fact confirms that NO is not sufficiently produced in the endothelium in the metabolic syndrome. In this case the very low concentrations of NO defend the endothelial cells from the aptoptosis.

The indexes of the insulin resistance and endothelium's functional state in patients with metabolic syndrome

\begin{tabular}{|l|c|c|}
\hline \multicolumn{1}{|c|}{ The figures } & $\begin{array}{c}\text { Healthy individuals } \\
\text { (Control) } \\
\mathrm{N}=15\end{array}$ & $\begin{array}{c}\text { Patients with metabolic } \\
\text { syndrome } \\
\mathrm{N}=54\end{array}$ \\
\hline Waist circumference(sm) & $75,7 \pm 0,61$ & $114,0 \pm 6,71^{*}$ \\
\hline Hips circumference(sm) & $96,0 \pm 7,44$ & $119,0 \pm 9,53^{*}$ \\
\hline Glucose level (on the empty stomach) mMole/1 & $4,5 \pm 0,52$ & $6,2 \pm 0,54^{*}$ \\
\hline Glucose level(after 2 hours) mMole/l & $4,9 \pm 034$ & $7,0 \pm 0,61^{*}$ \\
\hline Insulin(on the empty stomach) mk Unit/ml & $5,1 \pm 0,46$ & $15,2 \pm 0,78^{*}$ \\
\hline HOMA-IR & $1,02 \pm 0,01$ & $4,20 \pm 0,17^{*}$ \\
\hline & & \\
\hline The quantity of the desquamated endotheliocytes $\times 10 \mathrm{~m} / 1$ & $2,76 \pm 0,19$ & $5,8 \pm 0,46^{*}$ \\
\hline NO level mkMole/l & $26,51 \pm 1,24$ & $17,3 \pm 0,72^{*}$ \\
\hline Endotheline-1 concentration(Et-1) fMole/1 & $0,24 \pm 0,03$ & $0,763 \pm 0,06^{*}$ \\
\hline Villebrand factor concentration & $78,63 \pm 5,32$ & $102,81 \pm 4,71^{*}$ \\
\hline
\end{tabular}

Notes: the reliability of the differences $(\mathrm{P}<0,05)$ in comparison with the control group.

The concentration of the endotheline- 1 in patients with metabolic syndrome increased considerably. This fact clearly indicates that the increase of its production confirms the presence of the endothelial dysfunction in these patients. Endotheline-1 doesn't accumulate in the endotheliocytes, but is produced very fast under the influence of adrenaline, angiotensine II,vasopressin,trombone,cytoki nes and etc. Endotheline-1 affects the endothelial receptors and causes the releasing of relaxation factors. This activates the receptors of myocytes and stimulate vessels constriction. As the endothelin-1 acts mainly locally,it is clear that the increase of its production and releasing into the blood stream in the MS can cause the origin and aggravation of the endothelial dysfunction.

The level of the Villebrand factor in the MS was much more higher of the same figures in the healthy individuals. The most significant function of these factor is that it plays the role of the stabilizator for the procumulative protein FVIII:C,which circulates in blood as a tied complex and is a protein of adhesion in the process of haemostasis.

The increased levels of Villebrand factor indicate the endothelium damage in the MS.

To sum up the complex clinical-laboratory diagnostics in patients with MS provides the opportunities to reveal the damage of the functional state of the endotheliocytes(the increase of the quantity of the desquamated endotheliocytes and the functional activity of the Villebrand factor in the blood serum) and also decrease of the NO level as well as the increase of endotheline- 1 in the blood serum.

\section{Conclusions}

1. The patients with MS have the increased quantities of desquamated endotheliocytes and Villebrand factors.

2. The decrease of NO level and increase of endotheline- 1 in the blood serum are revealed.

\section{References}

1. Alexandrov O.V., Alechina R.M. Metabolic syndrome. The etiology and pathogenesis. Rus. Med. Journal. - 2006. № 6. - P. 50-55.

2. Butrova S.A. Metabolic syndrome: pathogenesis, clinics, diagnostics, therapy approaches. - 2001. -Vol. 9, № 2. - P. 56-62.

3. Zvyaginceva T.D., Gridneva S.V. The modern glance at the vascular endothelium in the gastrointestinal tract's normal and pathological state.Experim.clinic gastroent. - 2005. - № 4. - P. 6-12.

4. Kichigin V.A., Markova T.N., Bashkova I.B., Chuiko M.R. Adaptive systems of the organism in metabolic syndrome // Klin.meditsina. - 2012. - № 8. P. 50-54.

5. Markina N.V. The parameters of endothelial function and insulin resistance in patients with metabolic syndrome // Obesity and metabolism. - 2008. - № 14. - P. 18-23.

6. Petrichev N.N. The endothelial dysfunction. Causes, mechanisms, pharmacological correction. Under the edition of K.N. Petrichev. - St. Petersburg, 2003. - P. 484.

7. Chazova I.E., Michka V.B. P. 592.

The work is submitted to the International Scientific Conference "Fundamental and applied research in medicine", France, Paris, October 14-21, 2014 came to the editorial office on 18.11.2014. 


\section{THE LEVEL OF CYTOKINES IN THE BLOOD OF PATIENTS WITH ST-ELEVATION ACUTE MYOCARDIAL INFARCTION}

${ }^{1}$ Osipova O.A., ${ }^{1}$ Suyasova S.B., ${ }^{1}$ Shekhovtsova L.V., ${ }^{1}$ Nagibina A.I., ${ }^{2}$ Vlasenko M.A., ${ }^{3}$ Vlasenko O.A.

${ }^{1}$ Belgorod State National Research, Belgorod, e-mail: osipova 75@inbox.ru; ${ }^{2}$ Kharkiv Medical Academy of Postgraduate Education, Kharkov

${ }^{3}$ Kharkov National University

of V.N. Karazina, Kharkov

Inflammation plays a key role in the pathogenesis of atherosclerosis, and is involved, on the one hand, in the genesis, development, rupture, and repair of atherosclerotic plaque and, on the other, in post-reperfusion damage, remodeling, and scarring of myocardial tissue. It is also known that an exacerbated inflammatory state plays a role in the development and progression of heart failure.

Tumor necrosis factor alpha (TNF- $\alpha$ ) is an inflammatory cytokine synthesized in various blood, endothelial and smooth muscle cells, and in cardiac myocytes. The ubiquity and function of its receptors provide it with the capacity to modulate a diversity of inflammatory processes which are strongly involved in acute coronary syndrome (ACS) and in the development of heart failure due to its negative inotropic action, among others. Several lines of research have indicated that it is an independent predictor of mortality in patients with heart failure and advanced functional class, as well as in the chronic phase of myocardial infarction (MI).

Objective. To study the dynamic of inflammatory mediators - cytokines in ST elevation myocardial infarction (STEMI).

Materials and methods of research. 111 patients with STEMI aged 37 to 88 years were studied. During hospitalization heart failure (HF) was observed in 70 patients $(63,1 \%)$, according to Killip classification: class I - in 41 patients $(36,9 \%)$, class II - in $57(51,4 \%)$, class III - in 7 patients $(6,3 \%)$. HF persisted 21 days after AMI in 63 patients $(56,7 \%)$. The content of TNF- $\alpha$, IL- $1 \beta$, IL- 4 , IL-6 $(\mathrm{pg} / \mathrm{ml}, \mathrm{M} \pm \mathrm{m})$ cytokines was evaluated on day 1,7 and 21. Experimental group was composed of 20 patients with stable angina pectoris (SAP) and a control group (CG) - of 22 patients. There were no significant differences in gender or age between groups.

Results of research and their discussion. The baseline concentration of TNF- $\alpha$ cytokine in patients with STEMI was $569,6 \pm 54,2 \mathrm{pg} / \mathrm{ml}$, that was higher than in patients with SAP and control group $(\mathrm{p}<0,001)$. The concentration of TNF- $\alpha$ in group SAP was $57,5 \pm 11,3 \mathrm{pg} / \mathrm{ml}$ and $40,2 \pm 9,6 \mathrm{pg} / \mathrm{ml}-$ in control group. It significantly decreased to $66,8 \pm 36,5 \mathrm{pg} / \mathrm{ml}(\mathrm{p}=0,0001)$ and had no signifi- cant differences from other groups on day 7 . On day 21 TNF- $\alpha$ - content was the same. The baseline concentration of IL- $1 \beta$ was higher in patients with STEMI 550,3 $\pm 84,2 \mathrm{pg} / \mathrm{ml}$ in comparison to group with SAP $216,6 \pm 11,3 \mathrm{pg} / \mathrm{ml}$ and controls $145,6 \pm 12,6 \mathrm{pg} / \mathrm{ml}(\mathrm{p}<0,01)$. On day 7 the content of IL-1 $\beta$ did not change $609,8 \pm 98,6 \mathrm{pg} / \mathrm{ml}$, and it significantly decreased $417,8 \pm 71,6 \mathrm{pg} / \mathrm{ml}$ $(p=0,006)$ on day 21 . The content of IL- $1 \beta$ was significantly higher in patients with STEMI throughout the observation period as compared to other groups $(p<0,01)$. The baseline concentration of IL-4 in STEMI patients was higher $200,0 \pm 39,4 \mathrm{pg} / \mathrm{ml}$ than in group with SAP $77,7 \pm 27,5 \mathrm{pg} / \mathrm{ml}$ and CG $68,9 \pm 24,4 \mathrm{pg} / \mathrm{ml}(\mathrm{p}<0,01)$. On day 7 and 21 it remained high and was $129,6 \pm 38,3 \mathrm{pg} / \mathrm{ml}$ and $179,4 \pm 80,1 \mathrm{pg} / \mathrm{ml}$, respectively. The baseline concentration of IL-6 in patients with STEMI was higher $200,0 \pm 39,4 \mathrm{pg} / \mathrm{ml}$, than in patients with SAP $59,9 \pm 9,6 \mathrm{pg} / \mathrm{ml}$ and control group $50,7 \pm 8,4 \mathrm{pg} / \mathrm{ml}$ $(\mathrm{p}<0,001)$. It significantly decreased on day 7 and 21 to $90,1 \pm 21,2 \mathrm{pg} / \mathrm{ml}$ and $72,1 \pm 16,2 \mathrm{pg} / \mathrm{ml}$ $(p=0,001, r=0,02)$, respectively, that was significantly higher as compared to other groups during the observation period.

Conclusions. Indicators characterizing inflammation sharply increased on the first day of STEMI and persist in acute and subacute STEMI period, which probably indicates their impact on the progression of CHF.

\section{References}

1. Burian K., Kis Z. Elevated blood white cell count and coronary heart disease. Arch. Intern. Med. 2004; 164: 433.

2. Gérald L. et al. C-reactive protein, interleukin-6, and fibrinogen as predictors of coronary. Arterioscler. / Thrombos. Vasc. Biol. 2003; 23: 125 .

3. Gonzálvez M. et al. Prognostic value of tumor necrosis factor-alpha in patients with ST-segment elevation acute myocardial infarction. / Rev. Esp. Cardiol. 2007; 60: 12: 1233-1241.

4. Libby P., Ridker P. Inflammation and atherosclerosis. Circulation 2002; 105: 1135

5. Lindmark E., Diderholm E., Wallentin L., Siegbahn A. Relationship between interleukin 6 and mortality in patients with unstable coronary artery disease: effects of an early invasive or noninvasive strategy. JAMA 2001; 286: 2107-2113.

6. Gonzálvez M., Ruiz-Ros J.A., Pérez-Paredes M., et al. / Prognostic value of tumor necrosis factor-alpha in patients with ST-segment elevation acute myocardial infarction // Rev. Esp. Cardiol. 2007; - Vol. 60. - P. 1233-1241.

7. Nian M., Lee P., Khaper N., Liu P. Inflammatory cytokines and postmyocardial remodeling. Circulat. Res. 2004; 94 : 1543-1553.

8. Rodondi N. et al. Markers of atherosclerosis and inflammation for prediction of coronary heart disease in older adults. Am. J Epidemiol. 2010; 171: 5: 540-549.

The work is submitted to the International Scientific Conference "Modern Problems of Experimental and Clinical Medicine", Bangkok-Pattaya (Thailand), December 20-30, 2014 came to the editorial office on 12.11.2014. 


\section{Short Reports}

VISCERAL LYMPH NODES IN ABDOMINAL CAVITY OF DEGUS

Petrenko V.M.

St.-Petersburg,

e-mail:deptanatomy@hotmail.com

Degus (shrub rat) lives in South America, falls under the order of rodents, are used in experiments including program of investigations of sugar diabetes in USA and Europe. Lymph nodes (LN) in abdominal cavity of degus are not described in literature.

Materials and methods of research. I study visceral LN in abdominal cavity of 10 degus of
2-3 months old of both sexs by preparation after fixation in $10 \%$ neutral formalin.

Results of research and their discussion. All visceral LN in abdominal cavity of degus have bean's shape, but more often seen as oval or round because they are small. I divide these LN (fig. 1, 2) by topography on two groups:

1) the central LN, they lie about celiac-mesenteric artery (1) and caudal mesenteric artery (1);

2) the peripheral LN, they lie along branches of celiac-mesenteric artery - hepatic, splenic and cranial mesenteric arteries and ending branches of the last artery.

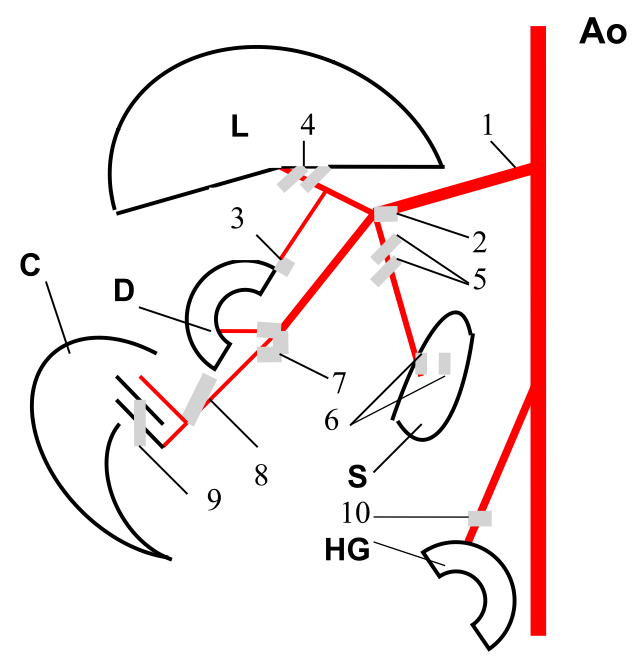

Fig. 1. Scheme of placing of visceral lymph nodes (LN) in abdominal cavity of degus: Ao - aorta; L - liver; S spleen; D - duodenum; C - caecum; HG - hind gut; 1 - celiac-mesenteric artery; 2 - paraaortic LN; 3 gastric LN; 4 - hepatic LN; 5 - pancreatic LN; 6 - splenic LN; 7 -pancreaticoduodenal LN; 8 - ileocolic LN; 9 - ileocaecal LN; 10 - caudal mesenteric LN on the caudal mesenteric artery

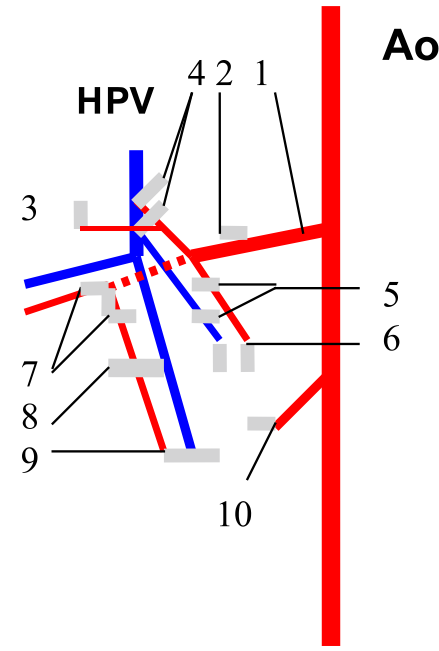

Fig. 2. Scheme of placing of visceral lymph nodes (LN) in abdominal cavity of degus: Ao - aorta; HPV - hepartic portal vein; 1 - celiac-mesenteric artery; $2-10$ - LN (designations as on Fig. 1) 
The short trunk of celiac-mesenteric artery in degus is the common beginning of celiac and cranial mesenteric arteries. Thus small paraaortic or petropancreatic LN (1), which lies about celiacmesenteric artery, is the common for two groups of $\mathrm{LN}$ - the celiac and the cranial mesenteric. Actually the celiac artery is absent because it divides on hepatic and splenic arteries at once. I find small hepatic LN (2) on the left side from hepatic portal vein, small gastric or subpyloric LN (1) - between stomack and bulb of duodenum, small pancreatic LN (2) - about splenic artery and vein, between body and tail of pancreas. Splenic LN (2), the most small among all visceral LN in the abdominal cavity, lie near hilus of spleen and tail of pancreas.

The cranial mesenteric artery in degus is short because it originates from branch of aorta and divides on ending branches about duodenojejunal flexure. The own cranial mesenteric (or pancreaticoduodenal, or interintesinal) LN (3-4) surround bifurcation of soname artery moreover the right of them (1-2) adjoin to the right branch and the left of them (2) - to the left branch (ileocolic artery). I find the conjestion of these LN at the beginning of common root of mesentery and mesocolon, between duodenojejunal flexure and head of pancreas, near confluence of right and left roots of cranial mesenteric vein. Ileocolic LN (1), the most large among visceral LN in the abdominal cavity of degus, lies at the end of common root of mesentery and mesocolon, about end of bundle of ileocolic blood vessels, about division of ileocolic artery on the end branches. Ileocecalis LN (1), unstable, with sizes about (a little smaller than) ileocolic LN, lies on the base of caecum, its medial (right) surface, between initial part of ascending colon and end of ileum, but in connection with ileum.
So visceral LN in abdominal cavity of degus are situated along odd visceral branches of abdominal aorta, among different inner organs. The head of pancreas separates paraaortic, hepatic and pancreatic LN (cranially) from pancreaticoduodenal LN (caudally), the common root of mesentery and mesocolon - pancreaticoduodenal LN from ileocolic LN, the base of caecum - ileocolic LN from ileocecalis LN, loops of intestine and ascending colon - cranial and caudal mesenteric LN.

Conclusion. Until I studied visceral LN in abdominal cavity of white rat $[1,2]$ and guinea-pig [3]. Quantity of visceral LN in abdominal cavity variates among these rodents: the largest - in rat, the least - in degus. These LN are situated always along odd visceral branches of abdominal aorta celiac, cranial and caudal mesenteric arteries and their branches. The largest numerous and variative groupe of these $\mathrm{LN}$ - the cranial mesenteric, the least - the caudal mesenteric (1-2).

Special topography, reduction of general quantity and subgroups of central cranial mesenteric LN in degus correlate with features of its regional organogenesis, first of all - the least liver among these rodents. Just liver regulates interactions between another organs and vessels in abdominal cavity, their growth and placing, including anlage LN.

\section{References}

1. Petrenko V.M. Topography of mesenteric lymph nodes in rat // Europ.J.Nat.Hist. - 2011. - № 4. - P. 6.

2. Petrenko V.M. Lymph nodes in basin of coeliac artery in rat // Europ.J.Nat.Hist. - 2011. - № 6. - P. 6.

3. Petrenko V.M. Visceral lymph nodes in abdominal cavity of the guinea-pig. Topography and classification // Europ.J.Nat. Hist. - 2013. - № 1. - P. 28-29. 


\section{Materials of Conferences}

\section{THE USE OF MICRO-NUCLEAR TEST \\ AS A METHOD IN A COMPREHENSIVE ASSESSMENT OF THE STUDENTS' FUNCTIONAL STATE}

Abakumova L.V., Khrenkova V.V., Zolotukhin V.V., Roginskaya A.A.

Southern Federal University, Rostov-on-Don, e-mail:alara2008@mail.ru

Education in modern school is inseparably linked with intense intellectual, emotional, physical exertion that in a certain combination can lead to exhaustion, which is expressed not only in the changes of the functional state of many body systems, but also in violation of cytogenetic homeostasis. In this regard, it could be useful to search for a system of methods which can easily and fast, without cumbersome equipment evaluate various parameters of the students' functional state, including cytogenetic homeostasis. Two groups of 10-11 year old children were examined. One group consisted of children of grammar school with advanced study of foreign language, not involved in sports, the second - pupils of secondary schools, regularly practicing athletic rock-androll for at least 1 year. During the examination the following aspects were examined: the profile of functional hemispheric asymmetry, the level of nervous processes mobility and the strength of excitation and inhibition, the level of school anxiety, the level of mental health and the development of fatigue. For the assessment of cytogenetic damage the microkernel test was used to detect the nuclear abnormalities in buccal cells. In both groups the following types of the nuclear abnormalities were identified: intussusceptions, kernel strangulations, microkernels, double and caudate nucleuses. The relative amount of nuclear abnormalities ( $\%$ ) varied from 2 to 18 , averaging to $6,88 \pm 0,43$. The most frequently met were intussusceptions and dual core. The dependence of the nuclear anomalies from physical or intellectual work was not detected. A moderate negative correlation between the strength of nervous processes and the relative number of epithelial cells with double and caudate nucleuses was revealed. A moderate positive correlation between anxiety and the relative number of dual epithelial cells was also discovered. Thus, the results of the study indicate the high vulnerability of cytogenetic homeostasis of children with high levels of anxiety and reduced strength of nervous processes, i.e. with reduced reserves of the regulatory systems, and, consequently, with reduced adaptive capacity of the organism as a whole. It allows, in our opinion, to come to the conclusion of the advisability of using micro-nuclear test in a comprehensive assessment of the functional state of students.

\section{MODERN CHANGES IN REGULATORY \\ BASE OF THE EDUCATIONAL PROCESS \\ IN UKRAINE AS LEGAL FORMATION \\ BASIS OF EUROPEAN STANDARDS OF THE SCIENCE AND EDUCATION}

Ermolenko T.I., Karnaukh E.V.

Kharkiv national medical university, Kharkov, e-mail:ella69k@mail.ru

July 1, 2014 after the Supreme Council of Ukraine took effect signed by the President of Ukraine Petro Poroshenko new Law of Ukraine № 1556-VII “Of Higher Education”, which is the basis of the legal framework of the educational process in Ukraine. This law establishes the basic legal, organizational, financial principles of higher education, creating conditions for strengthening cooperation between governmental agencies and businesses with higher education institutions on the principles of autonomy of higher education institutions, combining education with science and industry in order to prepare a competitive human capital for high-tech innovation and development, self-identity, the needs of society, and the state of the labor market for skilled professionals.

First will be treated as a collective body - the National Agency for Quality Assurance in Higher Education. In the scientific and educational activities will be significantly enhanced antyplahiatni rules and responsibility for them. This provides for the mandatory publication of all scientific innovative developments, implementations and fundamental theoretical work on various forms of available review and discussion. Constituted a new mechanism for the election of rectors of higher educational institutions, with the participation of all faculty and students. For rectors, deans and heads of departments prescribed limit tenure to two terms of 5 years each. In the National Agency remains accreditation of academic councils and appeals to their decision, and the right of final awarding degrees will now be at most universities. Public universities will now be able to place their own revenues from its education, research and training and production activities in the accounts of institutions of state banks. Reduced workload: one teachers from 900 hours to 600 hours per year, and in a number of hours of credit changed from 36 to 30 for students. Starting at 2016 is to introduce a new mechanism for electronic entry to higher education and the automatic placement of places of public order. Created conditions for increasing the mobility of students and teachers. For specified in the bill transition from the system of higher education will be deleted level junior specialist, introduced an associate's degree, canceled $\mathrm{PhD}$, instead introduced the following higher education degrees: Bachelor Jr., BA, MA, PhD. 
These new innovations pryntsipovi provided the legal framework of a constructive solution of actual problems that it is necessary at the present stage of formation of the system of science and education in Ukraine according to European standards.

The work is submitted to the International Scientific Conference "Actual problems of science and education”, Germany (Dusseldorf - Cologne), November, 2-9, 2014 came to the editorial office on 25.10 .2014

\section{CASE - TECHNOLOGY TO STUDYING HUMAN ANATOMY}

Ulyanovskaya S.A., Basova L.A., Serebrennikov A.D., Shumakova A.S., Smirnov P.V., Rogacheva O.D., Stepyreva A.A. Medical University SSMU Russian Ministry of Health, Arkhangelsk,e-mail: usarambler78@rambler.ru

The Conversion to a new educational standard requires the using of modern educational technologies and the forming of professional and general cultural competences. The Case-technology is applied in educational process at the Department of Human Anatomy during the summary sessions. It allows to check and fix the knowledge of a studied section of anatomy. The application of the Casetechnology during the summary sessions on the topic of blood supply and innervations of the limb promotes to forming of students' knowledge of Anatomy and Topography. This ability helps to use them in the future professional activity of the doctor. Moreover, it allows to form an integrated approach in the study of anatomy and topography and the ability to accurately determine the location and projection vessels and nerves to the skin surface.

The Case in Anatomy for students 1-2 years includes the clinical situation, which contains five exercises with missing initial data. To resolve this exercises students need to get additional information from the medical history, instrumental studies, etc.

During the training students should repeat the previously studied material, which is directly related to the theme of the class. All students of the group should take part in the solution of the case. The lesson lasts for 100 minutes.

1. The group is divided into 2 or 3 subgroups and 3 experts ( $5 \mathrm{~min}$.).

2 . The students acquainted with recommendations to the decision of the case $(2-3 \mathrm{~min}$.).

3 . The teacher presents the case. $(5 \mathrm{~min}$.)

4. Each member of the group individually studies the case. The discussion of options for individual solutions in each subgroup.

The preparation for discussion and debate (10 $\min . * 5)$

1. Debriefing and evaluation (10 $\mathrm{min}$.).

2. Concluding remarks by the teacher (2-3 $\mathrm{min}$.).
Experience of using Case-technologies in studying of Human Anatomy promotes the formation of clinical intellection of students and introduces an element of competition. It also motivates the students, gives a sense of satisfaction from their work and shows the great interest of students and a solid knowledge of the studied section.

The work is submitted to the International Scientific Conference "Modern education. Problems and solutions"THAILAND (Bangkok, Pattaya), December, 20-30, 2014, came to the editorial office on 08.12.2014.

\section{ENGLISH INTONATION AND THE RUSSIAN LEARNER}

Vishnevskaya G.M.

Ivanovo State University, Ivanovo

Intonation (Lat. 'intonare' - 'to pronounce', 'произносить') is a complex of expressive phonetic qualities of speech. Intonation is very obviously suprasegmental, “... since an intonation pattern by definition extends over a whole utterance or a sizable piece of utterance" (Trask 2007: 283). Intonation is a complex phenomenon in both form and function. Intensive intonation studies began not so long ago - in the $1950 \mathrm{~s}$ of the XX th century, in connection with the overwhelming achievements in the field of linguistics and the accumulation of many experimental data deduced from the study of many world languages. The implementation of modern precise methods of phonetic analysis have brought about astounding results that made it possible to pronounce intonology an independent department of linguistics having its own object of research and its own methods of analysis. Intonation began to be explored from different angles: linguistic, paralinguistic, sociolinguistic, didactic, esthetic, etc. As a complex phenomenon of oral speech, it attracts much attention on the part of specialists from different spheres of knowledge: philologists, linguists, literary critics, art critics, theatrical experts, sociologists, psychologists, acoustic engineers, etc.

The study of intonation is of prime importance for the practice of teaching and learning foreign languages. When one listens to the sound flow of speech in a foreign tongue it is intonation that catches one's ear first. The concrete meaning of an utterance may not be clear but the overall prosodic pattern of speech can help the non-native speaker decode the emotional state of the speaker and his attitude towards the partner in communication. It is common knowledge already that intonation is most difficult to master in the foreign language learning process. Wrong intonation does not only betray a speaker's foreign origin and jars upon a native speaker's ear - it can convey distorted meanings resulting in a serious misunderstanding in the process of communication. In this sense, as many phoneticians point out, intonation is much more important 
than accurately pronounced sounds of a foreign tongue: "English speakers are able to make a good deal of allowance for imperfect sound-making, but being for the most part aware of the far-reaching effect of intonation in their own language, they are much less able to make the same allowance for mistakenly used tunes" (O’Connor, Arnold 1973: 2).

Intonation studies in Great Britain from the very start were to a great extent pedagogically oriented. British phoneticians have contributed a lot into the teaching of English intonation to 'overseas students'. The most well-known book of this kind appeared at the beginning of the previous century: it was Harold Palmer's "English Intonation with Systematic Exercises" (1922). The work by David Crystal "Prosodic Systems and Intonation in English" (1969) has turned out to be the most fundamental work on the theory of suprasegmentals including the description of English intonation, followed by an outstanding work by Daniel Hirst "Intonation in British English" (1977). At the end of the XX th century intonation has stopped to be the 'Cinderella' of the linguistic sciences. The year of 1986 has turned out to be the Vinage Year in the intonation research: there appeared three significant books - a two-volumed 'bible' by the American linguist Dwight Bolinger ("Intonation and its Parts" and "Intonation and its Uses"), a monograph by the British scholar Alan Cruttenden ("Intonation") and a book by the German phonetician Elizabeth CouperKühlen ("An Introduction to English Prosody").

Alan Cruttenden was right in profecying (1986: 183) that the study of intonation was at a point from which there is likely to be significant and consistent progress in the next decade or two. He said it was "an exciting time for intonationists" (Op. cit.: 184). The beginning of the XXI st century announced the arrival of even greater interest in intonation research (Wells 2006).The goal of intonology nowadays is to give a description of intonation as a linguistic category possessing its own phonetic features and functions, its universal and specific characteristics in oral speech. Intonation is one of the most important means of language expression inseparable from lexical and grammatical characteristics of an utterance. Without intonation, there is no utterance. Intonation is an essential component of the discourse structure of speech. It is the music of speech used for both - meaning and expression, reflected in the attitude of the speaker: "... every utterance we make contains, in its intonation, some indication of this attitude. Clearly, the speaker's words and grammatical structures are used with the intention of expressing his attitude; but intonation gives additional information; that is why different actors can give such widely varying interpretations of the same role in a play. We may regard the words as a rough guide to the meaning, and the intonation as giving greater precision and point, but this is not to say that intonation makes a greater contribution to the whole that does the verbal structure; indeed the intonation without words would give a very vague impression of the total meaning. Nevertheless, it does provide important information which is not contained in any of the other features of utterances, and without this additional information there would be many more imprecisions and ambiguities in English speech than in fact there are" (O’Connor, Arnold 1973: 5). Sometimes intonation is dispensable but in most cases, it is essential, it carries the main load in shaping the speaker's meaning. Elizabeth Couper-Kühlen writes (1986: 209): "The fact that speakers have the option of giving their utterances informational, illocutionary, attitudinal and textual 'meaning' with intonational means alone constitutes strong evidence for the function of intonation in language. This function is not fully 'distinctive' in the classical sense, but it is potentially of such farreaching import that students of language can hardly afford to ignore it".

Intonation mistakes are the ones that are most difficult to overcome for a foreign language learner. The language learner is burdened with his native tongue intonation knowledge lying dormant in him and influencing him in the perception of the foreign tongue intonation patterns. The latter ones are conveying linguistic meanings different from the native tongue, though sometimes seeming almost the same in form. The foreign language learner is often misled by the fact that there are universals in intonation the melodical component of which is based on the fall and rise of the voice pitch practically in every one of the world languages. The language learner does not at first feel the difference in the tone configuration and its other parameters pertaining to the suprasegmental characteristics of the target language.

On the level of performance, the foreign language learner is also under the strong influence of his native tongue intonation habits, which leads to the wrong suprasegmental organization of the utterance in the choice of melody, peaks of prominence placement, placement of pauses, rhythm arrangement of an utterance, etc. The distorted perception of foreign speech determined by the 'phonological sieve' of the native tongue can explain the causes of pronunciation mistakes resulting into the foreign quality of oral speech.

The teaching of intonation remains to be less effective and more hazardous than the teaching of other phonetic aspects of a foreign tongue. There is still no adequate and learnable description of English intonation for Russian learners (Vishnevskaya, Levina 2007). There are substantial reasons for it. Firstly, it is due to the nature of intonation itself, being a very complex sound phenomenon. Secondly, existing descriptions of intonation seem to be incomplete. Thirdly, intonation is less tangible than other phonetic characteristics of oral speech. However, there are ways of improving suprasegmental qualities of oral speech in the process of the English language acquisition process.

\section{References}

1. Bolinger D. Intonation and its Parts: Melody in Spoken English. Stanford, 1986 
2. Bolinger D. Intonation and its Uses: Melody in Grammar and Discourse. L., 1989.

3. Couper-Kühlen E. An Introduction to English Prosody. Tübingen, 1986.

4. Cruttenden A. Intonation. Cambridge, 1986.

5. Crystal D. Prosodic Systems and Intonation in English. Cambridge, 1969.

6. Hirst D. Intonation in British English. L., 1977.

7. O'Connor J.D., Arnold G.F. The Intonation of Colloquial English. L., 1973.

8. Trask R.L. Language and Linguistics: The Key Concepts. 2nd ed. N. Y., 2007.

9. Vishnevskaya G.M., Levina T.V. English Suprasegmental Phonetics. Ivanovo, 2007.

10. Wells J.C. English Intonation: An Introduction. Cambridge, 2006

The work is submitted to the International Scientific "Science and education in modern Russia", Moscow, November 13-15, 2014 came to the editorial office on 09.10.2014.

\section{VOCAL SCHOOL OF WEST KAZAKHSTAN REGION \\ Vorfolomeyeva O.V. WKSU after Utemisov, Uralsk, e-mail: muzikant-70@mail.ru}

The modern local system of vocal pedagogics is connected with names of teachers - Shilimova N. vocalists. Savelyeva V.T., Savelyeva L.F., Mauletova T.K., Lymareva L.A., Moldagainov A., Rakhimova Zh.A., Kuzhakov K.K., Bizhanov K.K. and others. In this row the tendency of continuity, fidelity to the methodical principles of vocal school is very brightly traced. Very often pedagogics and concert and performing activity of teachers representatives of vocal art of the West Kazakhstan region go in parallel. Such practice, by means of scenic performance allows to illustrate the whole complex of vocal and technical and art means of vocal art. Carrying out parallels of this sort the pedagogics art bears in itself an inherent value. The article analyzes the period of the formation and development trends of vocal pedagogy in Western Kazakhstan in the period from the 60 s to the present day. In this regard, it is necessary to determine the direction of vocal schools in the region through the study of methodological principles teachers vocalists.

The combination of vocal and technical means to ensure a high level of performance, clearly defined methods-these notions are related to the term vocal school, a much broader distinguishing feature of which is the identity of national culture, the originality of this style, a certain standard of sound ,as well as representatives vocal pedagogy, as holders of the system . Here we will talk about the theory, methodological bases and practice of vocal performance.

Not separating vocal pedagogy Western region from all vocal pedagogy of Kazakhstan, it is necessary to tell about the presence damn vocal school, influencing the formation and development of not only the education, but also musical art of the region as a whole.
Portraits of teachers, stages of their formation in professional role allow to understand more deeply the principles of vocal pedagogics going from widely known directions, performers, teachers, representatives of various national schools. Despite uniform understanding of modern vocal equipment as standard, regional conditions in close connection with original musical culture nevertheless can leave the marks.

Savelyeva V.T., was born in 1927 in Uralsk. She was the third child in a family of the chairman of Workers' and Peasants' inspection. Her mother ended 4 classes of school, but by nature possessed talent of the organizer, the creative atmosphere reigned in a family, children grew and versatily developed in the most unexpected directions. In the early childhood Valentina and her brother had a passion for house performances which came to the end with domestic display for all comers children was shown. Here statements of young talents got a response from the grateful nursery of public. Valentina grew very active child, with pleasure took part in outdoor games, safely crossed the river, on - was boyish fearlessly ready on the most unexpected projects. Always she liked to sing. Her passionate love to singing was distinctly shown at youthful age, then it arrives in the Ural musical school, in a class of the teacher Galaktionova Anna Feodorovna. The teaching staff of school of a wartime was presented by very strong teachers, at will of destiny appeared in Kazakhstan, evacuated of the most different corners of the country and from abroad.

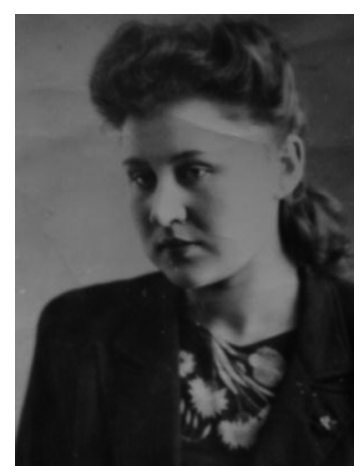

Savelyeva V. 1948

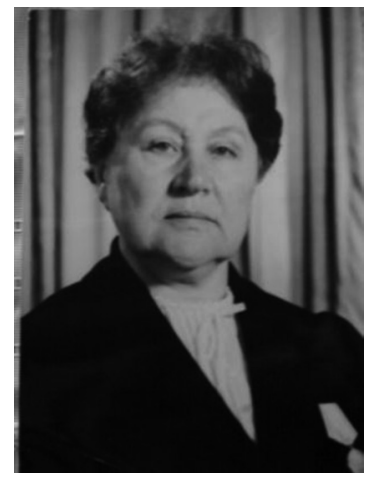

Savelyeva V. 1990 
Among them: Muravyeva A.F., Avdeeva N.K., Shilimova N.E., Bronn I.I. etc. Evacuation during war of troupe of the Karelian-Finnish operetta (Petrozavodsk) that allowed Valentina to be present on musical rehearsals and performances became an important factor of formation and receiving musical experience, practically learning aurally many voice parts. In a difficult wartime of Valentine it was necessary to work in film distribution, to prepare displays of movies, to transfer heavy boxes with movies on the brittle maiden hands, sometimes it is wearisome rising on ladders. Without noticing fatigue, Valentina overcame difficulties to pay additional classes for a piano.

During his studies in music College she displayed and develops voice (mezzo-soprano) large scale, mellow tone, it was their first experience of artistry, which is very important for the novice singer. In the vocal repertoire is the aspiration to the genre of Opera.

Of course, a favorite thing demanded improvement vocal skills, acting, and, after graduation, Valentina Timofeevna decides to do in the Saratov state Conservatory. Sobinov. At the same time she meets her fate - talented musician Saveliev Yuri Ivanovich, which covered many ways, have a great, happy musical family in which there is a place for creativity, for joint weekdays and holidays. The years of study at the Conservatory 1951-1956 became uneasy. At this time student born a daughter, and in order brilliantly to graduate from the Conservatory, it was necessary to sacrifice personal life, temporarily transfer of the child, to settle in difficult social conditions, often without the most necessary everyday amenities. But such difficulties only tempered character, strong and confident young woman. She comes in the class of Professor Ustinov N.E. Nikolai EverEve Ustinov, returning after the great Patriotic war from Moscow to his home Saratov, was a Professor of the chair of solo singing in the Saratov Conservatory. Before the war he graduated from the Moscow Conservatory and post-graduate, then was a soloist of the Musical theatre of Stanislavsky and Nemirovich-Danchenko, before the war and during the war - the soloist of ensemble of the Soviet army.

Vocal Department began its existence from the moment of opening of the Saratov state Conservatory. These were the few classes under the guidance of the outstanding performers of that time: M.E. Ter-Minassian, Medvedev and Eichenwald-Dubrovskaya, who brilliantly graduated from the Moscow Conservatory classes J. Galvani and G. Nissen-Salomon. They brought up a whole pleiad of outstanding masters of vocal art: A. Mozzhukhina, G. Pirogov, F. Mukhtarova and many others. Galaxy of teachers of the Department of vocal art, where at that time studied Valentina Timofeevna, relying on strong vocal-pedagogical technical base, raised famous singers: G.A. Kovaleva - people's artist of USSR, Professor of the St. Petersburg Conservatoire (student of Professor
O.N. Strezhevoy); Smetannikov L.A. - people's artist of USSR, Professor, head of the Department of Academic singing SGK them. L.V. Sobinov (student of Professor A.I. Bystrov); Popov U.L. - people's artist of USSR, soloist of the Saratov Opera house (student of Professor A.I. Bystrov); Tarasov A.V. zasluzhennyy artist of Russia, Professor (pupil O.N. Strezhevoy); G. Yakovlev - honored artist of the Russian Federation (student of Professor F.E. Hartman); Korsunskaya O.N. - honored artist of the Russian Federation (student of Professor V.N. Denisova); Ladinska L.G. - honored artist of the Russian Federation (student of Professor V.I. Udodova); Dovgaleva N.I. - people's artist of the Russian Federation (pupil of the deserved actress of the Russian Federation, associate professors N.A. Sheveleva); Pakhomov M.I. honored artist of the Russian Federation (the disciple of Professor V.N. Udodova) and many others.

Valentina Timofeevna Savelyeva becomes Sobinov a scholarship student, takes the vocals for mezzo-soprano ("May night", N. Rimsky-Korsakov, "Eugene Onegin" by P. Tchaikovsky) in the Opera Studio of the Conservatoire. An important factor in the development of professional vocal mastery of the future singer was an acquaintance with little-known teacher of that time Artamonov, who Valentina Timofeevna within a few months he took vocal lessons. This meeting was crucial. Although the teacher, who gave lessons at home, did not seek popularity, its methodology has had a tremendous impact on young vocalist. It was about the vocal technique, techniques, which Valentine had never worked. These were special techniques Italian equipment Belcanto. According to the author, probably, at that time she did not realize that these lessons will be crucial in the life of the young singer.

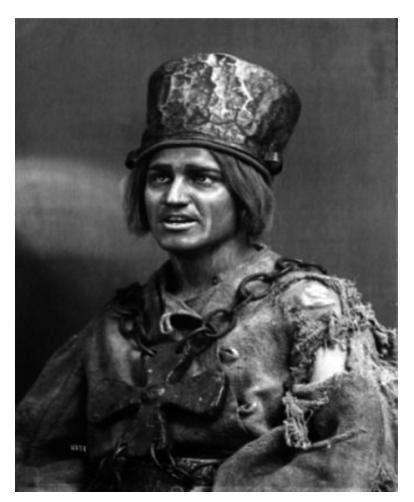

Artamonov (Tomanov) N.

Artamonov (Tomanov) Nikolai Stepanovich, 20.7.1885, Saratov - 17.7.1971, Leningrad Opera singer (lyric-dramatic tenor). Studied singing with 1905 in St. Petersburg Conservatoire, he took lessons from A.N. Amfiteatrov-Levitskaya. On the Opera stage performed with 1912goda. From 1915 
soloist of the Petrograd theatre of musical drama in 1917. Opera S. Zimin (Moscow), in 1918-gg. and 1926-gg. as a soloist of Petrograd-Leningrad Hatoba, sang in MileGate. Toured in Kiev, Odessa, Baku (1924-25), Novosibirsk, Moscow. Performed on the stage until 1933. He was the first performer of the part of the Trader (Opera "Black Yar" A. Pashenko, 1931) Best party: Prince ("mermaid by A. Dargomyzhsky), Herman (the Queen of spades" by P. Tchaikovsky), Lensky ("Eugene Onegin" P. Tchaikovsky), Hoffmann (Les Contes d'hoffmann J. Offenbach), Duke ("Rigoletto" by Verdi. Verdi). Also in his repertoire were party: the Fool ("Boris Godunov" by M. Mussorgsky), Prince Vasily Shuisky ("Boris Godunov" by M. Mussorgsky), Vladimir Igorevich ("Prince Igor" A. Borodin), Prince Sinodal ("the Demon" by A. Rubinstein), Bob (the "enemy force" A. Serov, 1920), the Trick ("Eugene Onegin" P. Tchaikovsky), Soil ("Sadko" N. Rimsky-Korsakov); Faust (districts. Opera Charles Gounod), Alfredo (La Traviata). Verdi). In different years of his partners on stage were outstanding singers with a world name: Century A. Belyanin, E.A. Bronsky, P.M. Zhuravlenko, N. Kalinina, N.N. Kuklin, L. Lypkivskyi, A.I. Popov-Zhuravlenko, Ekaterina Sabinina, F.I. Chaliapin. He sang in the performances under the direction of S. Yeltsin, E.A. Cooper, D.I. Pohitonov.

Records of its voice on phonograph records in Petersburg ("Zvukopis", 1911) remained. Artamonov N.S. kept the memories of creative and scenic work in sketches: "About collaboration with F.I. Shalyapin at the Maryinsky Theater and about a trip abroad" (1963) - in TsGAZ USSR (with 1992 - I Grew. the state. archive of phonodocuments RGAFD).

In Savelyeva V.T. memoirs. Artamonov told about the general teacher-vocalist, at which to it as well as to F. Shalyapin, has the luck to take the lessons belcanto. It was a question of Usatov Dmitriye Andreevich (1849-1913) - the Russian actor of the opera (tenor), the teacher, the author of many romances, F.I. Shalyapin's first and only teacher.

The native of the Petersburg family of the serf at the count D.N. Sheremetev, it possessed a strong and beautiful voice. In 1873 I graduated from the Petersburg conservatory (K. Everardi's class). He sang about 10 years in the Bolshoi theater of Moscow, is the first performer of parties in Tchaikovsky's operas: Lensky; Andrey ("Mazepa"), Vakula ("Cherevichki"). Among its opera parties: Alfred, Almaviva; Eleazar ("Maccabee" of Rubenstein), Sobinin ("Ivan Susanin"),- the Bayan ("Ruslan and Lyudmila"), Raul ("Huguenots"), Faust; Beppo ("Cordelia" of Solovyyov), etc. In 1890-1894 the vocal teacher, taught singing in Tiflis where free of charge I trained F.I. Shalyapin infinitely loving the teacher. Shalyapin so cabled after the concert in 1903: "Dear teacher! Having sung excellent the concert, with sincere feeling of love it is remembered dear Dmitry Andreevich and we drink for it and spouses his health". Having moved to Yalta in 1894, it gave private lessons of singing, in his house often there were known composers, musicians A.S. Arensky, A.K. Glazunov, V.I. Rebikov, A.A. Spendiarov and other cultural figures.

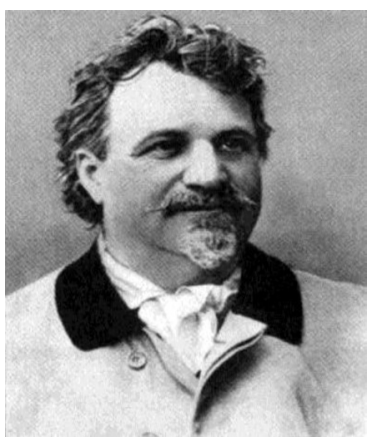

Usatov D.

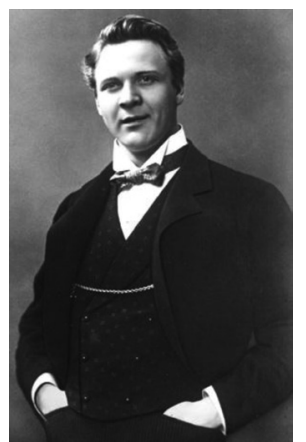

Shalyapin F.

The meeting and occupations with Artamonov pushed Valentina Timofeevna to deeper studying of techniques of a vocal. She passionately was fond of studying of methodical literature of different authors, re-reads and summarizes grants and textbooks, listens to samples of the best opera music, analyzes vocal equipment of the well-known performers. Thus, within several years, on the basis of the studied literature, the receptions tested on a personal example the technician of a vocal, it develops own understanding, vision of vocal school. Thus, the vocal equipment which was mastered by Valentina Timofeevna, belongs, first of all, to the best and long traditions of the Russian vocal schools of Moscow and Petersburg, and also in unique Italian equipment of Belcanto.

After the termination of Saratov Conservatory Valentina Timofeevna within 6 years worked at the Saratov academic opera and ballet theater. Her active creative and concert life begins. Except an opera scene, in the spirit of Soviet period, the young singer together with the spouse acts at concert venues, propagandizing the best samples of classical and variety music, shows the art at the Festival of youth and students in Moscow in 1957. In 1962 Savelyev' family comes back to Uralsk where active pedagogical, creative and concert work in the 
Ural musical school begins, and later - again created Institute of culture and arts (nowadays Faculty of culture and ZKGU arts). For many years of work, from 1962 to 2005, Valentina Timofeevna let out a number of the remarkable vocalists nowadays known not only in Kazakhstan, but also beyond its limits.

In formation of vocal pedagogics the important role is got by creativity of the professional composers propagandizing vocal art of the Western Kazakhstan. So in the last decades XX and the beginning of the XXI century were created remarkable classical works of the Kazakh vocal genre at composers of our edge I. Zhakanov, E. Nurymbetov, V. Sharonov, A. Shevelev, V. Irkhin, A. Moldagainov, E. Gaysagaliyev, etc. Inexhaustible richness of the Kazakh folklore and song tradition, in close cooperation with the principles of professional music became their dramaturgic and musical basis. Stage of scenes of our city and area became the arena where before a look of the modern viewer the panorama of all variety of vocal genres is developed. In the 90 th years of the XX century and the first decade of the XXI century in the region develops and reaches blossoming one of the most difficult genres of music - vocal within which are created as the works close on form and content to classical, and the new genre directions, expressed in transformation of the traditional folklore and modern directions. The big love at the Ural audience was received by vocal interpretations of the Kazakh monodichesky music. Especially wide popularity I won the folklore and ethnographic movement expressed in aspiration of revival of ancient traditions, left practice of a daily existing of the Kazakh music.

The known singer, the musicologist and the composer Ashir Moldagainov, whose creative gift left a considerable trace in musical culture of Kazakhstan. Having cast in the lot with Cisural area, it combined concert and performing activity of the soloist of regional philharmonic hall with teaching work at Institute of arts of Dauletkerey WKSU and musical college of Kurmangaza. These fruitful years Ashir Moldagainov, whose name as the composer, it was lit by a bright star the song "Ayaulym, Armanymday Asyly" which the Kazakh radio and the television from 1966 to 1984 opened the programs performed by the national actress of the USSR Roza Baglanova, composed symphonic poems "Zhayy_Ta_y" and "Flower of Naryn", created a set of songs and romances. "Oh, if could express in a sound ..." These words from the known romance performed by Fedor Shalyapin can become a keynote of creativity of the singer. A. Moldagainov's compositions which irrespective of their form, structure of instrumenal maintenance, application of these technical means, speak to us about the main ideals of the person and present events, are filled with the serious contents and an original intensity of emotions.
Among them the unfinished opera "Aisha Bibi-Karakhan”, Akku-Armand (the lyrical poem), a number of songs social, patriotic "The song of friends", "The song of the Ural students", pedagogical subject "Why-asker", "The first teacher", "Anа тілі", "Ustazym", songs and the romances devoted to native immense Kazakhstan where it is possible to see wide geography "Kyzylorda a tank tany", "Actobem Jeanne olky", "Balkhashym менін”, "Braids орденді Kustanai", "Astana-zhas a calla", "Taraz waltzes", etc. children's lyrics in a lullaby genre "to Eldi, Bots", “Ana эльдиi”, "Joint stock company mother", and certainly favourite many, the love lyrics filled with tenderness, the sincere experiences, all richness of an inner world of the composer - in the works "Maple Branch", "Love", "Do Not Forget Me", etc. Literary basis of vocal creativity of A. Moldagainov verses of poets of V. Irkhin made, A. Ospanov, U. Ementaevoy, Armand Moldagainov, S. Rybakov, R. Nurpeisov, A. Baygozhayev, and poetic lines of the composer.

Compositions of the author, are got by the deep contents, concentration of thought, bright figurativeness. Deep and serious processes of modern life, lyrical and children's instructive subject, ways of development and formation of independent Kazakhstan, vital philosophy - all this imperiously interferes in compositions of the composer, and the main successive task consists in it for representatives of composer school of the Western Kazakhstan and A. Moldagainov, as most her gifted representative.

The silvery voice of the singer deserved the actress of the Republic of Kazakhstan Zhumaganym Rakhimovoy in the world of music well is known - a coloratura soprano as if being poured by all flowers of a rainbow, reflects the width of beautiful steppes, deep poetry of spiritual beauty of the people and many years pleases judges of vocal art of our edge. The destiny presented it with a fine voice, and therefore in the songs she tries to bear to people good and love, heat of soul, beauty of the nature - everything without what life would be cloudy and sad. In 1993, to pleasure of fellow countrymen, Zhumaganym Rakhimova returned to the native land from Alma-Ata where after the conservatory termination it long time worked with such known collectives as the National orchestra of Kurmangaza, a folklore and ethnographic orchestra "Otrar Sazy". In gold fund of the Kazakhstan radio and television more than 200 songs, romances and arias are stored in its execution. In a word, it arrived to Uralsk with rich creative baggage which with love transfers now to young generation, carefully sharing the skill with students of faculty of culture and WKSU arts.

Since the childhood fascinated by singing Kulyash Bayseitovoy and Bibigul Tulegenovoy, Zhumaganym Rakhimova many devotes years himself to creativity in the West Kazakhstan philharmonic hall of G. Kurmangaliyev. In repertoire 
of the singer Zhumaganym Rakhimovoy the most different in genres and to styles of work: national songs, ancient romances and classical works J. Haydn, W.A. Mozart, Ch. Gounod, Mukan Tulebayev and Ahmet Zhubanov, whose works, according to her, never will lose the spring freshness and color.

The vocal pedagogics of our edge is closely connected with a name of the remarkable teacher Taisiya Mauletova which class left a number of bright representatives of vocal art. I graduated from Almaty musical school of Tchaikovsky on a class of choral conducting at Zoya Zheraspayeva, in parallel the second office on a vocal class at the teacher Gilda Alekseeva in 1965. The same year I arrived in Almaty state conservatory of a name of Kurmangaza in Vocal art in a class of associate professor Natalya Nagulina. Natalya Feliksovna in the years of war was evacuated to Kazakhstan from the Kiev state conservatory. On formation of professional qualities of the young vocalist, a great impact had visits of concerts of world famous singers: S. Lemeshev, I. Kozlowski, Z. Sotkilava, M. Magomayeva, T. Sinyavskoy, D. Gnatyuk, and also opera and ballet statements of GATOB to them Abay, the most various concerts of symphonic, instrumental music.

After completion of study of Mauletov $\mathrm{T}$. in the part of group of graduates she got in the direction to the Chimkent institute of culture, consolidated the gained knowledge and skills of the young specialist in a pedagogical field. From 1971 to 1983 the seniority of Taisiya Kiyakpayevna was connected with Chingirlausky children's music school where she held a position of the director. These years it improves the pedagogical and vocal skill, will organize amateur performances, choral collective, an orchestra and soloists. In 1983 Taisiya Kiyakpayevna is sent to one of the oldest musical educational institutions of Kazakhstan - the Ural musical college. The office of a vocal was created from the strongest vocal teachers - Savelyeva V.T., Savelyeva L.F., Shilimova N.E., Lymareva L., Zhigalov N. and others. Becomes later it one of leading teachers at again opened institute of culture and art of Dauletkerey by it where it works hand in hand with Savelyeva V. T. great teachers. Moldagainov A., Rakhimova Zh.A., Bizhanov K.K. At the heart of Mauletova T.K going in close interrelation with a technique of L. Dmitriyev's technique, the thorough solfedzhirovaniye (surely with cor- rection of the teacher), the theoretical analysis, work on breath, flexible phrasing and dynamics, fundamentals of physiology and psychology in formation of the vocalist prevails. Important value is given to vocal training in Panofka, Abt, Zeydler, Konkone, Glinka, Varlamov, Lemeshev's systems, Sobinova-of representatives of the Italian, German, Russian vocal schools. For years of long-term work Taisiya Kiyakpayevna let out the great vocalists who are vanguard of vocal our art regiona-Kuanshaliyeva R., Hairkhanov A., Usayeva E., Idriskaliyev K., Zhaumbayev T., Akhmanova G. and others. Along with Mauletov T.K. pedagogical activity actively gives concerts with a philharmonic wind band, an orchestra of the Kazakh national tools in the cities of Russia and Kazakhstan. In Taisiya Mauletova's concert repertoire of work of an opera and chamber genre: arias, romances, P. Tchaikovsky, S. Rachmaninov, G. Sviridov, N. Rimsky-Korsakov, M. Glinka, D. Puccini's vocal cycles, D, Rossini, W. Mozart, M. Tulebayev, L. Khamidi, party from operas "Snow Maiden", "Imperial Bride", "Melancholy", "Seville Barber", "Rigoletto", "Birzhan and Sara", "Abay", etc.

Today with big confidence it is possible to speak about the developed vocal school of the Western Kazakhstan, with its education system, activity of the concert organizations, pedagogical potential. Difficult process of its evolution proceeds and today. Estimates, certainly, can't be unambiguous. Only time eliminates all casual and highlights the true values.

\section{References}

1. Bagadurov V. Sketches on stories of vocal pedagogics. M.: "Muzgiz", 1956.

2. Glinka of M. Notes. Leningrad "Muzgiz", 1962.

3. Dmitriyev L. Bases of a vocal technique. - M.: "Music" of. 1968 .

4. Morozov V. Secrets of the vocal speech. "Science" Leningrad, 1967.

5. Shalyapin F. of article, statements, memoirs. - M.: "Art", 1957-1958. Vol. 1-2.

6. Stanislavsky K. Work of the actor on. - M.: “Art”, 1951.

7. Theater. The theatrical encyclopedia (under the editorship of A.P. Markov). - M.: Soviet encyclopedia, 1961-1965. - T. 5.

The work is submitted to the International Scientific Conference "Strategy for science education", Spain-France (Barcelona-nice-Monaco-Monte-Carlo-San Remo, Cannes), 26 July - 2 August 2014, came to the editorial office on 09.07.2014. 


\section{Materials of Conferences}

\section{PRECISION THICKNESS METER PHASED ARRAY}

Guva A.A., Nikonova G.V., Shchelkanov A.I. Omsk State Technical University, Omsk, e-mail:ngvlad@mail.ru

Proposed construction of ultrasonic thickness using technology ultrasonic phased array for the automated control of the details.

Thickness measurement - precision research method that eliminates the traditional error. One of acoustic methods of nondestructive testing, occupies a leading position, is the ultrasonic thickness. This methodology is based on the electromagnetic-acoustic method of sending and receiving ultrasonic vibrations, which allows a high level of accuracy to determine the thickness of the object to be measured, not causing him thus no damage [1].

Ambiguity of reference for the control of parts of complex shape with a small radius of curvature of the surface and equidistant - drawback of this method the operator can not know the position of the surface relative to the contact. It must vary the angular position of the sensor to at one point of time the incident ultrasonic wave is directed along the normal to the surface of the part. The position of the sensor depends on the angle of the emitting ultrasonic vibration input in the product and the length of the path that they run to the front of the sensor. This is especially significant for the measurement of small thickness.

The solution of the problem is the use of ultrasonic phased array technology in the design of precision thickness gauge.

The main feature of the ultrasonic phased array technology-computer-controlled amplitude and phase of the excitation pulses in multi-individual piezoelectric transducer [2]. Excitation of the piezoelectric elements can be implemented in such a way to be able to control the parameters of the ultrasonic beam, such as angle, focal length, focal spot size by a computer program.

Thickness consists of microprocessor control and computing (MCC), the reference oscillator (Goch), generator trigger pulses (GTP) time intervals measuring (TIM), digital-to- analog converter (DAC), a comparator, a temporary selector, keyboard, LCD display and a piezoelectric transducer phased array (PTPA) [3].

In the radiation MCC commands the simultaneous launch GTP and TIM. Pulse with GTP arrives at PTPA and radiated into the product. In receiving the reflected ehoimpuls adopted PTPA amplified, subjected to amplitude and time selection and enters the TIM signal the end of the pulse counting Goch. The resulting code at the output goes to the TIM MCC, which, after appropriate calculation gives the value of the thickness on the indicator. In receive mode, the amplifier comes from PTPA pulse sequence: pulse reflected from the front face of the product; pulses longitudinal and transverse waves reflected from the bottom surface of the article; reflections impulses in prisms PTPA. Owing to the small phase shift some impulses PTPA perceived as one.

The amplitude of the received pulses depends on the thickness of the product, and the differences of the coefficients of attenuation of ultrasonic waves in a product, the surface roughness of the product quality and acoustic contact. To reduce the influence of these factors, it is used in the selection of the amplitude at a variable voltage threshold, which is carried out using a DAC and comparator. DAC controlled MCC determines the threshold voltage. The comparator selects the pulses that exceed the threshold voltage level.

Temporary selection pulses output from the comparator is performed by using a time delay circuit and the selector, controlled MCC. Time selector selects the longitudinal momentum of the wave reflected from the bottom surface. The measurement time interval is made TIM, which counts the number of pulses per Goch time between pulses reflected from the front face, and the momentum of the longitudinal wave reflected from the bottom surface. Impulse wave reflected from the front face of the product is for TIM start pulse counting pulses Goch. Impulse longitudinal wave reflected from the bottom surface of the article is the terminal count pulse.

The measured time interval MCC enters for processing the measurement results and the formation of image information. When the processing of measurement results taken into consideration delay in the prism is regarded as a known value. The value of the speed of propagation of longitudinal acoustic waves in the material of the measured product is installed in thickness meter using the keyboard or measured on a sample of known thickness. Recorded in the memory of the gauge dataset can be transferred to a PC for analysis, processing and use of the documentation. To transfer the recorded data to a computer in a procedure thickness meter transmission measurements from the instrument memory to the PC.

The measurement process is independent of subjective assessment of the operator increases the measurement accuracy. Such a construction of the gauge using a phased array technology allows for control of parts in automated production and excludes subjective operator error when installing the sensor on the details.

\section{References}

1. Kliuev V.V. Nondestructive testing and diagnostics: Directory / V.V. Kliuev, F.R. Sosnin, A.V. Kovalev, et al.; Ed. V.V. Klyueva. 3rd ed.-M.: Mechanical Engineering, 2005. $-656 \mathrm{p}$ 
2. Olympus NDT. Introduction to Phased Array Ultrasonic Technology Applications. USA, Waltham, 2007.

3. Gouva A.A., Shchelkanov A.I. Ultrasonic Thickness Gauge for automated production of parts //Actual problems of modern science. Proceedings of the III Regional Youth NPK with international participation. - 2014. - P. 109-111.

The work is submitted to the International Scientific Conference "Modern science technologies", Spain (Tenerife), November 21-28, 2014, came to the editorial office on 16.11.2014.

\section{THE ACTUAL SCIENTIFIC AND EDUCATIONAL PROGRAM OF SMALL SPACECRAFTS ENGINEERING}

\author{
Kovalev I.V. \\ Siberian State Aerospace University \\ named after academician F. Reshetnev, \\ Krasnoyarsk,e-mail: kovalev.fsu@mail.ru
}

The Siberian State Aerospace University and its strategic partners are described. Two satellites series are considered.

At the present time the Siberian State Aerospace University named after academician M.F. Reshetnev (the SibSAU) in cooperation with the strategic partners - the Joint-stock Company "Information Satellite Systems" named after academician M.F. Reshetnev" (JSC "ISS") and the Scientific Center of Krasnoyarsk under Siberian branch of Russian Academy of Sciences - implements the program of creation of the scientific and educational, technological microsatellites series [1-3].

The SibSAU is one of the leading Russian Universities in the aerospace technologies domain. The University develops on principles of the research university and implements the integrated system of preparation of specialists and scientific brainpower for the enterprises of space domain. The specialists preparation programs combine educational process, research activities and students work practice in the leading Russian space enterprises [4]. SibSAU implements the innovation educational programs [5-11] and performs scientific researches in close cooperation with the strategic partners - the base enterprise JSC "ISS" and the scientific institution Scientific Center of Krasnoyarsk under Siberian branch of Russian Academy of Sciences, which have cooperatively created the subdepartments, scientific and educational laboratories and research centers $[12,13]$.

The JSC "ISS" is one of the leading enterprises of Russian space industry which possesses the technologies of complete space complexes creation cycle starting by the design to the spacecrafts control in all types of orbit - from low circular to geostationary. During its activities the enterprise has taken part in implementation of more than 30 Russian and international space programs in the domains of communication, retransmission, television, navigation, geodesy and scientific researches. The enterprise has designed, manufactured and launched about 1200 spacecrafts of 50 different types which distinguish by the high reliability and are intended for operation in low circular, circular, high-elliptical and geostationary orbits.

The objectives and tasks of the program for creation of the scientific and educational, technological microsatellites series being implemented $[14,15]$ :

- development of the integrated system of the engineering education (distance learning system, laboratory sessions performing using the ground stations of microsatellites control etc.);

- implementation of the design-oriented educational technology during formation of the space domain specialists professional capacities (students' participation in designing and manufacturing of satellites, service systems and scientific devices);

- scientific experiments in space (development of the Earth natural resources space monitoring methods, multifunctional nanomaterials, hightemperature superconductors and other intelligent materials use in space);

- technological development and obtaining of the flight qualification for the advanced service systems, devices and elements of the satellites (of the attitude determination and control subsystem, electric power subsystem, thermal control subsystem and other subsystems with the increased lifetime).

In 2007 the SibSAU in cooperation with the JSC "ISS" and the Scientific Center of Krasnoyarsk under Siberian branch of Russian Academy of Sciences have concluded the strategic partnership agreement on creation of students' small satellites series according to which the program of technological, scientific and educational satellites regular creation and following launch was adopted (smka. sibsau.ru). Due to this program the technological work-out in space and flight qualification obtaining will be provided for the new elements of satellites and space systems developed on the basis of the University. The SibSAU is the single Russian higher school which will perform the manufacturing of elements and the assembly of microsatellites, the mounting of technological and scientific instruments as well as the part of small satellites tests directly on the basis of the joint scientific and educational center "Space systems and technologies" and the industrial resource center "Spacecrafts and space systems" which has the clean room and production facilities for these purposes.

\section{The "Yubileyniy" satellites series}

In 2008 the first satellite of the "Yubileyniy" satellites series has been developed and put into operation (Fig. 1). Structurally the "Yubileyniy" satellite consists of the unpressurized instrumentation module formed by the hexagonal frame on which the solar array panels are mounted and by three transversal panels - upper, middle and lower. On-board equipment is accommodated in the instrumentation module as well as on the outer surface of the upper panel. On the upper panel which is directed towards the Earth during the satellite operation the attitude 
determination subsystem elements are locatedmagnetometer and transversal beams with balancers, receiving and transmitting antennas as well as the scientific equipment: three Earth sensors to receive the data on the Earth radiation in the infrared range of wave lengths and to research the space-time radiation of the Earth day-time and night-time atmosphere in the apparent spectral range.

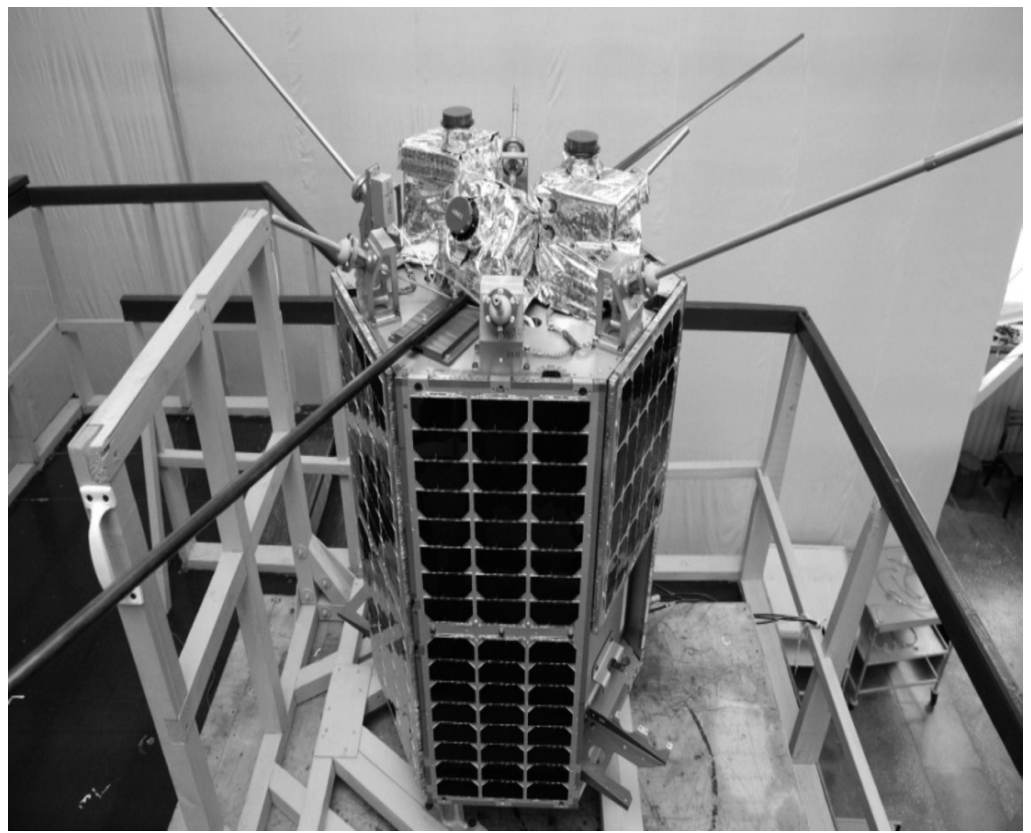

Fig. 1 Photo of the Small satellite "Yubileyniy"

On the middle panel the DOKA-B equipment is installed that includes on-board computer, receiving equipment operating in frequencies of $145 \mathrm{MHz}$, transmitting equipment operating in frequencies of $435 \mathrm{MHz}$ and radionavigation on-board equipment.

On the bottom there are located: magneticgravitational attitude determination system providing the satellite longitudinal axis orientation towards the Earth in nominal mode, navigational equipment antenna, experimental sun sensor and "Radek" equipment dedicated to check the efficiency of application of the nano-coatings developed in the SibSAU for radiation protection of satellites' electronic components.

One of the purposes of the unified platform of this satellite developed in the JSC "ISS" is to create conditions to perform the educational and scientific and technical experiments in space. As the satellite attitude control subsystem elements the self-deploying mechanical micro systems based on composite materials are used. Such mechanical systems allow creating the transformable large-size spatial structures based on lightweight tubular rods in space. The rods extension mechanisms allow spatially allocating the objects with the mass about $10 \mathrm{~kg}$ at distances of tens of meters.

The solar arrays panels mounted on the frame are made based on the three-stage gallium arsenide and allow providing electric power to the satellite on-board equipment in the sunlit part of orbit. The selected frame shape provides the required value of the solar array effective area, at different satellite position relative to the Sun. In eclipse orbit the electric power is provided to the equipment by the nickel-metal-hydride battery. The battery is not the separate unit, its elements are included in the instrumentation power and control unit which accommodates all the automatics of the electric power subsystem; all this is included in the DOKA-B equipment.

The peculiarity of this satellite is the passive thermal control subsystem: the required temperature conditions are provided by unregulated ratio of optical factors on object structure elements surfaces, heat-insulating elements, electric heaters and heat pipes which provide thermal conditions for the DOKA-B equipment.

In the frame of the project "Research of radiation shields efficiency at radiation effects of the Earth.

The telemetry data from the equipment are received, processed and stored in the SibSAU students' Satellite Control Center.

The small satellite "Yubileyniy" ensured the performance of research, experimental and educational tasks.

The "Yubileyniy" satellite launch started the information program dedicated to the most important 
stages of the space exploration (speech messages, slides in SSTV format, simulation of signals of the first satellite).

It created conditions for use of information from the small satellite by the leading Russian higher schools in teaching and educational objectives.

Performance of scientific and technological experiments:

- Ensuring the flight qualification of promising Sun and Earth sensors;

- Acquisition of data on the Earth radiation in the infrared range of wave lengths;

- Research the space-time radiation of the Earth day-time and night-time atmosphere in the apparent spectral range;

- Working-out the satellite orientation assessment methods according to the information from the experimental Sun sensor and the compact magnetometer;

- Check of the efficiency of application of the nano-coatings developed in the SibSAU for radiation protection of satellites' electronic components;

- Ensuring the flight qualification of the promising multifunctional unpressurized platform for satellites with the mass of $30-100 \mathrm{~kg}$;

- Working-out the technology of small satellite concurrent injection into the operational orbit by the "Rokot" launcher.

All the organizations that have taken part in development and creation of the small satellite obtained the significant scientific and technical groundwork for the future and made their contribution to the preparation of highly skilled specialists for the space industry of Russia.

The launch of the small satellite "Yubileyniy" together with three nominal satellites was performed from the "Plesetsk" launch site on the 23/05/2008.

Besides the scientific-technical and experimental tasks the small satellite was intended to perform one more function not less important. The creation of this satellite allowed performing preparation of young specialists on the basis of project-oriented educational technology for the first time. The students took part in all stages of satellite creation: from the design documentation development to the satellite in-orbit control.

Operation control of the satellite that has been successfully operating in space for four years is performed by the Satellite Control Center formed in the SibSAU with the JSC "ISS" participation. The students receive the telemetry information from the satellite in real-time mode there, learn to decode it and to control the satellite.

The Satellite Control Center main functions are control and coordination of interactions between technical means of satellite deployment, maintenance in nominal operation mode and replacement. The Center fulfills the following tasks:

- long-term and operational planning for the satellite and the ground control center technical facilities operation;
- organization of technical facilities synchronous operation in real time;

- control of the checking information packets generation and transmission on-board the satellite;

- reception, processing, display and archiving the telemetry information from the satellite;

- analysis and prediction of the satellite technical state;

- organization of the current navigational parameters measurements and their processing;

- organization of preventive measures and contingencies recovery;

- performing the Satellite Control Center technical facilities operability monitoring in accordance with the technical requirements;

- organization of information protocols, queues, priorities, flows, archives access;

- providing the automatic information exchange with the ground control center facilities and interacting complexes.

The "Mikhail Reshetnev" satellites series

On the second satellite "Mikhail Reshetnev" (MiR) has being launched in August 2012 and five new university developments will be approbated already. The students of SibSAU have developed and manufactured: on-board computer, remote data interface unit, Earth remote sensing camera and laser corner reflector intended to measure the distance from the satellite to the Earth. The function of the devices is the working-out the new control unit and the digital line of the Earth remote sensing information transmission in space.

The small satellite MiR is designed on the base platform of the "Yubileyniy" satellite with extended mass and power performances (Fig. 2).

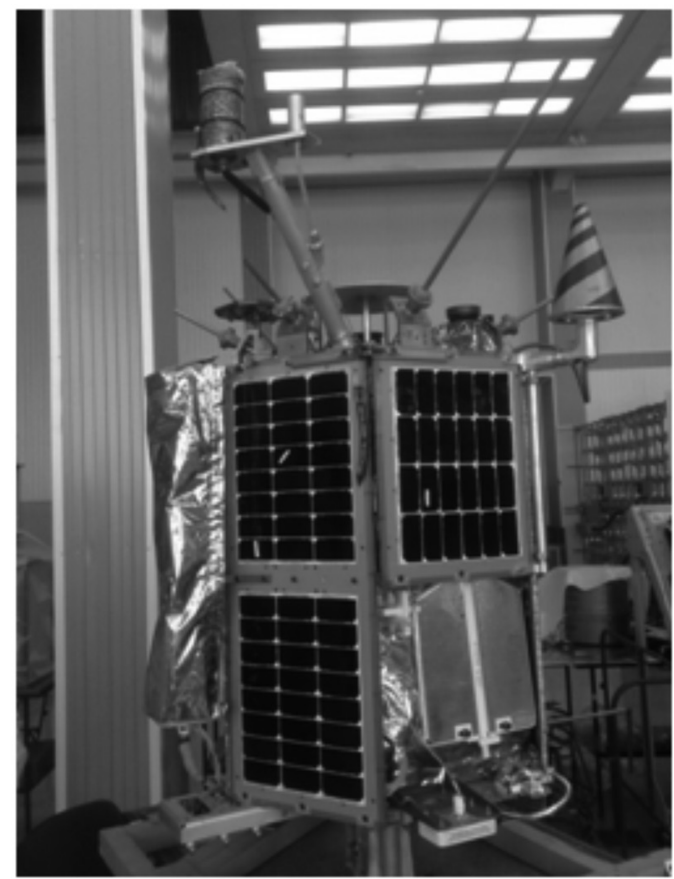

Fig. 2. Small satellite"MiR" 
The tasks performed during creation and operation of the small satellite "Mikhail Reshetnev":

- Obtaining the scientific and technical groundwork in the field of competitive space technology and technologies of new generation for use in defense, scientific and commercial purposes;

- Creation and working-out in field conditions the experimental parts of small satellites and advanced satellites of the JSC "ISS";

- Obtaining the experience of creation and operation of the satellites for the Earth remote sensing;

- Improving the existing forms of project-andteam preparation of specialists for the JSC "ISS" with the participation of the SibSAU students on the basis of the joint scientific and educational center "Space systems and technologies" (SEC SST);

- Creation and launch of the satellite in honor of the fiftieth anniversary of the JSC "ISS" and the SibSAU.

- Working-out and acquisition of the contour heat pipes production technologies.

\section{The opportunities for students}

The students of technical specialities during studies have the unique possibility to directly control the Russian small satellites ("Yubileyniy", "Mozhaets", "Chibis" and future "Mikhail Lomonosov" and "Baumanets 2") and satellites of the Technical University of Berlin (DLRSAT, TUBSAT), receive and process the telemetry information (sat.sibsau.ru). In the center there are also studies on the program simulator of modern telecommunication satellite "Express-AM" that fully simulates operation of all satellite service subsystems and is used for test work-out of onboard control system and learning to operate the real satellite (joint development of SibSAU and JSC "ISS" specialists). The Students' SCC of the SibSAU is an important ground segment of the orbit group of technological, scientific and educational small satellites being created by the University and the partners.

In 2010 in the frame of the international project "Reformation of the educational programs in the field of space technology in Russia, Ukraine and Kazakhstan" (CRIST) according to the European Commission program TEMPUS the international distributed network of the University's small satellites control stations was created for the successful and full-scale small satellites control. This network included SibSAU, the Technical University of Berlin, the State Aerospace University of Samara, the Moscow Aviation University and several leading institutions of higher education of Russia, Ukraine and Kazakhstan. In 2011 in the frame of the project on the TEMPUS program SibSAU and the Technical University of Berlin were remotely united through the Internet. Thus the students of SibSAU obtained the unique possibility to receive the information from the Russian University's satellites and satellites of the Technical University of Berlin.

\section{Conclusion}

The speciality of the program on students' microsatellites series creation being implemented is that the JSC "ISS" uses them as an experimental field for working-out new devices and systems. The most part of the payload on-board equipment mounted on these satellites is used for the first time. The new equipment gets the flight qualification inorbit, after that it could be used in creation of big spacecrafts.

As a result of implementation of the presented project in Krasnoyarsk due to the joint efforts of JSC "ISS", SibSAU and SCK SB RAS the successful integrated system is created for the space industry manpower development using the unique technologies of project-and-team students' work, balancing between innovations and traditions, education and scientific research and maintaining the flexibility in educational trajectory construction. It allowed organizing students' and postgraduate students' work on the real projects directly in the SibSAU starting from the design and the short-series manufacturing of space engineering devices and elements to the creation of small satellites.

\section{References}

1. Kovalev I.V., Loginov Y.Y. Innovative activity of the University in the field of space systems and technologies. Higher education in Russia. - 2011. - № 6. - P. 16-21.

2. Kovalev I.V., Loginov Y.Y. The Development of regional technological platform "Information-telecommunication and space technologies for innovative development of Siberia". Vestnik SibGAU. - 2012. - № 2. - P. 168-173.

3. Kovalev I.V., Loginov Y.Y., Cybulski G.M. The Establishment of a regional centre for receiving and processing remote sensing data of the earth on the territory of Krasnoyarsk region. Resetdevice reading. - 2013. - So 1, № 17. - P. 256-257.

4. Kovalev I.V., Karaseva M.V. English-German-English frequency dictionary on system analysis in electronic engineering and the aerospace industry. Siberian state aerospace University. Krasnoyarsk, 2013. -216 p.

5. Kovalev I.V., Zelenkov P.V. Automation of formation of information and terminological basis multilinguistic learning technologies. Distance and virtual learning. - 2005. - № 3t. - P. 68-81.

6. Kovalev I.V., Agarunov S., Lomakov P.M. Algorithmic customization tools information-terminological basis in the field of aerospace engineering. Aerospace instrument-making. 2007. - № 9. - P. 67-71.

7. Kovalev I.V., Karaseva M.V., Leskov V.O. Information terminological basis as a set of lexically related components. Vestnik SibGAU. - 2009. - № 1. - P. 54-56.

8. Kovalev I.V., Leskov O.V., Karaseva M.V. Intralingual associative fields in multilinguistic adaptive-learning technology. System management and information technology. - 2008. № 3.1 (33). - P. 157-160.

9. Usachev V., Kovalev I.V. Adaptive Technology of the Education Quality Control. В сборнике: 9th International Scientific and Practical Conference of Students, Post-graduates and Young Scientists - Modern Techniques and Technologies, MTT' 2003 Proceedings. - 2003. - P. 251-253.

10. Kovalev I., Kovaleva T., Susdaleva E. Effective information training technology based on the learner's memory state model. Modelling, Measurement and Control D. - 2000. - T. 21, № 3-4. - P. 11-26.

11. Kovalev I.V., Kovaleva T.A., Karasyova M.V., Ezhemanskay S.N. System Aspects of Multilingual Adaptive- 
Training Technology Organization and Usage: Proceedings of Modelling and Simulation, MS'2004 AMSE International Conference on Modelling and Simulation, MS'2004. sponsors: University Lyon 1, France, Assoc. for the Adv. Model. and Simul. Tech. Enterprises, AMSE, French Research Council, CNRS, RhoneAlpes Region, Hospitals of Lyon. Lyon-Villeurbanne, 2004

12. Kovalev I.V. Creating the question of improving the accuracy and reliability of the test system and simulation of weightlessness in space. Vestnik SibGAU. - 2014. - № 2 (54). P. $106-109$.

13. Kovalev I.V., Stupina A.A., Tsarev R.U. Planning the development of the cluster structure of the automated contro system of satellite communication. Aerospace instrument-making. - 2006. - № 12. - P. 26-30.

14. Kovalev I.V., Nurgalieva Y.A., Gritsenko S., Usachev A.V. To the problem of selecting the structure of the automated system of aircraft control. Vestnik SibGAU. - 2009. № 3. - P. 105-110.

15. Kovalev I.V., Engel E.A., Tsarev R.Ju. Programmatic Support of the Analysis of Cluster Structures of FailureResistant Information Systems. Automatic Documentation and Mathematical Linguistics. - 2007. - T. 41, № 3. - P. 89-93.

The work is submitted to the International Scientific Conference "Actual problems of science and education" Germany (Dusseldorf - Cologne), November, 2-9, 2014 came to the editorial office on 29.10.2014

\section{MEASUREMEN.T PHASE NOISE CRYSTAL OSCILLATOR}

Nikonova G.V., Novikov S.M., Petrov A.V.

Omsk State Technical University, Omsk, e-mail:ngvlad@mail.ru

One of the most important characteristics of high frequency oscillators (HFO) used in communication devices, navigation equipment, digital devices, systems orientation autopilot aircraft, missile guidance systems, radar equipment - is the phase noise generated oscillations, in other words, the distortion of the generated signal [1]

The ideal signal generated by a crystal oscillator (CG) should not be distorted shape, and location of its edges should exactly repeat from period to period, that is, it must exactly match their mathematical function, $U=U_{o} \sin (t / T)$ for a sinusoidal signal where: $T$ - the period of oscillation, $t$ - current time.

Waveform distortion due to the nonlinear regime autogeneration, electrical frequency multiplication, and other factors, spectral analysis explains "admixing" to the basic ideal signal with frequency $\omega$ of its harmonics with multiple frequencies $(2 \omega$, $3 \omega, 4 \omega \ldots)$ and amplitudes corresponding to that signal distortion [2].

In that case, if the waveform distortion is random chaotic can speak of a phase noise in the signal. Phase noise in the reference oscillator leads to a deterioration of the radio systems: degradation of the radio communication, reduce the accuracy of location of objects in the GPS navigation data transmission losses, reduced sensitivity of radar and others. Today, phase noise is one of the main pa- rameters of the $\mathrm{CG}$, which reduce is of paramount importance

Phase noise measurement is performed on special analyzers spectral analysis, determine how its power is distributed over the frequency range from zero to infinity. In practice, it is usually limited by the operating frequency detuning of the signal in the range from $0,1 \mathrm{~Hz}$ to $100 \mathrm{kHz}$ (and sometimes from $0,01 \mathrm{~Hz}$ to $1 \mathrm{MHz}$ ) [3].

The measurement results are presented in the form of the curve $L(\Omega)$, where $\Omega$ - frequency analysis $H z ; L(\Omega)$ - logarithm of the spectral power density of the "noise" of the signal $S(\Omega)$, measured in a $1 \mathrm{~Hz}$ bandwidth at a distance from the lasing frequency $\Omega: L(\Omega), d B c=10 \log [S(\Omega) / 2]$.

The dependence of $L(\Omega)$ is divided into three zones differing slope $L(\Omega) / \Omega$ : proximal zone occupies a range of from $0 \Omega$ to $10 \mathrm{~Hz}$ has a slope $L(\Omega) / \Omega$ about $30 \mathrm{dBc}$ per decade (a decade - the change $\Omega 10$ times ); middle zone, which occupies the frequency range $\Omega$ approximately $10 \mathrm{~Hz}$ to $10 \mathrm{kHz}$, is characterized by a slope $L(\Omega) / \Omega$ from 10 to $20 \mathrm{dBc}$ per decade; far zone (or noise-floor), starting from $\Omega=10 \mathrm{kHz}$, has almost no slope of $L(\Omega) / \Omega$.

In the formation of the CG noise involved various sources, concentrated in the oscillator circuit, temperature control system and a quartz resonator (CR). Their influence on the noise CG occurs by a complex interaction between them and the parameters of the resonator. Despite the well-known convention, it is assumed that the phase noise $L(\Omega)$ at different detuning $\Omega$ generated by various sources of noise.

Far field (noise-floor) is formed mainly intrinsic noise buffer amplifier. Thus, the higher the level of the generated signal at the input of the buffer amplifier, the lower the contribution of noise in the CG and the lower level $L(\Omega)$. Limit reduce noise-floor limited Johnson noise equal at room temperature $-174 \mathrm{dBm} / \mathrm{Hz}$. Therefore, the lower levels of phase noise reduction required temperatures CG [4].

The middle zone $L(\Omega)$ is formed by noise amplifier oscillator, closed through the CD positive feedback. At the level of phase noise in this area influences the loaded quality factor KR: the higher the $Q_{L}$, the lower the frequency of the upper middle zone and the middle zone of the transition frequency in noise-floor.

In the formation of the near field dependence $L(\Omega)$ involving the same sources as in the middle zone, but added to them related to the influence of noise on the resonator and the thermostat. Effect of noise on the thermostat due to fluctuations in its temperature, called through the thermodynamic effect of the frequency fluctuations of the CD. Usually this factor is concentrated in the range of $0,01 \Omega$ to $5 \mathrm{~Hz}$, and can be reduced by optimizing the design of the oven and increase the thermodynamic stability of the CR. 
Sources of noise in the CR have flicker nature and occur mainly due to defects on the wafer surface and the subelectrode areas such as scratches, quartz particles, defects adhesion film electrodes, and others. In addition to improving the quality of processing and application technology of the plate film electrodes to reduce noise above factors resulting increase in the thickness of the plate (excitation at higher harmonics of the motor), provides a reduction ratio "surface" energy (fluctuating due to these defects ) to the energy fluctuations in the volume of the plate.

In addition to the above factors, a significant effect on the noise of the CG has its own noise varicap in series with the $C R$ and the noise voltage regulator, which is the right choice for a low-noise $\mathrm{CG}$ is crucial.

\section{References}

1. Ochkov D.S. Influence of the frequency of the reference signal by the value of the parasitic phase shift of the quartz oscillator. - M.: Radar and communication 2007. - № 4.

2. Veshkurtsev Y.M. Algorithms for determining the moments of the distribution of the random process with characteristic function / Y.M. Veshkurtsev, S.M. Novikov // Proceedings of the universities. Ser. Radioelektronika . - 1990. - V. 33, № 7. - P. 94-96.

3. Nikonov A.V. Frequency synthesizer for automatic control systems at ultrahigh frequencies / A.V. Nikonov, G.V. Nikonova // Instruments and experimental techniques. 1993. - № 1. - P. 114-118.

4. Nikonov A.V. A frequency converter with controllable characteristics. / A.V. Nikonov, G.V. Nikonova // Measurement Techniques. - New York, 2008. - V. 51, № 1. - P. 74-81.

The work is submitted to the International Scientific Conference "Modern science technologies" Spain (Tenerife), November 21-28, 2014, came to the editorial office on 16.11.2014. 